UNIVERSIDADE DE SÃO PAULO

FACULDADE DE FILOSOFIA, LETRAS E CIÊNCIAS HUMANAS DEPARTAMENTO DE CIÊNCIA POLÍTICA

PROGRAMA DE PÓS-GRADUAÇÃO EM CIÊNCIA POLÍTICA

DANILO CESAR FIORE

Bases Sociais e Interiorização: O Predomínio Eleitoral do PSDB

Paulista (1994-2014)

v. 1

VERSÃO CORRIGIDA

SÃO PAULO

2016 
UNIVERSIDADE DE SÃO PAULO

FACULDADE DE FILOSOFIA, LETRAS E CIÊNCIAS HUMANAS

DEPARTAMENTO DE CIÊNCIA POLÍTICA

PROGRAMA DE PÓS-GRADUAÇÃO EM CIÊNCIA POLÍTICA

\section{BASES SOCIAIS E INTERIORIZAÇÃO: O PREDOMÍNIO ELEITORAL DO PSDB PAULISTA (1994-2014)}

\section{DANILO CESAR FIORE}

Dissertação apresentada ao Programa de Pós-Graduação em Ciência Política do

Departamento de Ciência Política da Faculdade de Filosofia, Letras e Ciências Humanas da Universidade de São Paulo, para obtenção do título de Mestre em Ciência Política

Orientador: Prof. Dr. André Vitor Singer

DE ACORDO com a versão corrigida.

(versão corrigida)

SÃO PAULO 
Autorizo a reprodução e divulgação total ou parcial deste trabalho, por qualquer meio convencional ou eletrônico, para fins de estudo e pesquisa, desde que citada a fonte.

Catalogação na Publicação

Serviço de Biblioteca e Documentação

Faculdade de Filosofia, Letras e Ciências Humanas da Universidade de São Paulo

Fiore, Danilo Cesar

Bases Sociais e Interiorização: O Predomínio

Eleitoral do PSDB Paulista (1994-2014) / Danilo

Cesar Fiore ; orientador André Vitor Singer. - São

Paulo, 2016.

$146 \mathrm{f}$.

Dissertação (Mestrado) - Faculdade de Filosofia, Letras e Ciếncias Humanas da Universidade de São Paulo. Departamento de Ciência Política. Área de concentração: Ciência Política.

1. Estudos Eleitorais. 2. Comportamento Eleitoral - 3. Partidos Políticos . 4. PSDB. 5. Política Subnacional. I. Singer, André Vitor, orient. II. Título. 
À linda Mari, por estar comigo neste mundo-moinho 


\section{AGRADECIMENTOS}

Um adágio de autoria desconhecida no mundo acadêmico recomenda capricho e zelo redobrado na redação dos agradecimentos e das conclusões de dissertações e teses - afinal, estas provavelmente serão as sessões a serem lidas com a maior atenção por amigos, familiares e integrantes diversos do círculo social do autor.

Prudentemente, resolvi começar, então, pelo final: a despeito do lugar-comum e da aparência protocolar, inicio esta sessão com os necessários agradecimentos a todas e todos que, por razões de espaço, não foram citados nominalmente (mas que tiverem suma importância para a conclusão deste trabalho). Esclareço ainda que as muitas contribuições foram fundamentais para os acertos e eventuais achados desta pesquisa porém, todos os erros, omissões e possíveis problemas ficam por conta única e exclusiva deste autor.

Agradeço ao professor André Singer pela orientação paciente e, na melhor acepção dos termos, crítica e rigorosa. Agradeço-o também pelas disciplinas ministradas ao longo do curso e pela oportunidade de ser monitor em sua matéria na graduação. Estar em seu convívio intelectual ao longo dos últimos três anos e meio foi gratificante e desafiador. Generosamente, aceitou orientar um aspirante a cientista político com alguns dados à mão e um tema (complexo) na cabeça. Espero que possamos continuar esse diálogo em passos futuros. Em seu nome, agradeço a todas (os) as (os) integrantes do Grupo de Pesquisa Pensamento e Política no Brasil, com as (os) quais pude aprender muito e que fizeram sugestões valiosas a este trabalho em inúmeras oportunidades.

A todas (os) as (os) prestativas (os) funcionárias (os) do Departamento de Ciência Política (Rai, Léo, Vasne, Ana Maria e Márcia), agradeço pelo auxílio. Em nome dos coordenadores da pós-graduação no período, Rogério Arantes e Rossana Reis, agradeço a toda a comunidade do DCP, à qual tive a felicidade de integrar-me. Agradeço ainda aos novos colegas e amigos que tive a felicidade de fazer principalmente àqueles com quem estive "perdido" ao longo dos últimos três anos (Maria Letícia, Rafael, Henrique e Vinicius).

Agradeço ao Instituto Datafolha, ao CESOP/Unicamp, à Fundação SEADE, ao TSE e ao TRE-SP pela disponibilização dos dados que embasaram esta pesquisa. 
Agradeço aos professores Timothy Power, Lorena Barberia, Cícero Araújo, Antônio Sergio Rocha, Elizabeth Balbachevsky e Oswaldo Tanaka pelas disciplinas ministradas ao longo deste período, essenciais para minha formação, e à professora Rachel Meneghello por relevantes comentários a uma versão preliminar da pesquisa. Agradeço ainda aos professores Oswaldo Amaral e Lorena Barberia (novamente) pelos apontamentos preciosos quando da qualificação, e aos professores Oswaldo Amaral e Elizabeth Balbachevsky (ambos novamente) pela arguição na banca de defesa.

Aos amigos da vida profissional (Dani, Fabi, Fernandão, Gabi, Zé Augusto, Letícia, Maíra, Maria Elisa, Maurício e Stê), agradeço pela convivência prazerosa na "repartição", nos inúmeros almoços e nos fundamentais bares / sessões de terapia coletiva. Ao Baider, Leandrinho, Theo e Tiago, uma menção honrosa pelo apoio com as bases de dados, fluxogramas e valiosas sugestões. Por meio da dra. Eliana Radesca (que tanto tem me ensinado), agradeço às (aos) colegas da Saúde pela recepção acolhedora.

Aos amigos da faculdade e da tortuosa vida semi-política - Andreza, Anita, Badaró, Caio, Fred, Fatah, Ernesto, Sérgio, PH, Nádia e tantas (os) outras (os) que não caberiam nesta seção -, um agradecimento pela convivência infelizmente pouco constante, mas sempre prazerosa e instigante. Ao Léo e ao Jonas, agradeço também pelas importantes sugestões e conversas de desabafo sobre as nossas pesquisas.

São poucas as pessoas que, chegando à casa dos trinta anos, cultivam com afinco as amizades que fizeram na primeira infância. Sou um desses privilegiados. Agradeço aos amigos Arthur (a quem agradeço também pelo auxílio com os dados), Bruninho, Leis, Marcel, Téri, Vitones e Vinicius Panacho (compadre de todas as horas) por estarem comigo nesta turma tão especial, cujos laços de amizade só fazem fortalecer ao longo do tempo. Agradeço também às namoradas e esposas, que tornaram esse grupo ainda melhor - com uma menção especial à Lore, pela importante ajuda com a revisão.

À Dili, agradeço pelo carinho, pelo apoio e pelos bolos de cenoura.

Numa família com cinco tios maternos e três tios paternos, seria necessário um anexo apenas para citar nominalmente todas as primas, primos, tios, tias, entre outros. Na esperança de contemplá-los, agradeço aos meus avós maternos (Adelina e Leonídio) e paternos (Elma e João, o qual infelizmente não conheci) pela feliz empreitada que resultou nesta nossa grande família. 
Não poderia deixar de agradecer, porém, algumas pessoas nominalmente. À tia Lindomar, cuja dedicação ao próximo não tem equivalência, agradeço por sua necessária presença entre nós. À Andrea, agradeço pela polivalência no amor: primairmã, madrinha e grande amiga. Ao Mizinho, pelo carinho sempre presente, ainda que distante. Aos tios Eduardo e Wagner, pelo apoio nos momentos mais difíceis.

Aos meus irmãos, Juliana e Maurício, agradeço pelo afeto que não se pode medir em palavras (ainda que tenham escolhido o time errado). Ao Mó, um agradecimento pelo apoio na tortuosa reta final, e à Ju, pela proteção zelosa ao irmão caçula. E um agradecimento ao Kim e à Ana, por estarem com a gente.

À Elis e ao Joãozinho, agradeço pela presença iluminada e cativante, bálsamos de esperança e alegria que sempre me fazem recordar que a vida vale a pena.

À Mari, temo não conseguir expressar tamanha gratidão. Digo sem receios que, sem ela, essa dissertação não existiria. Seu apoio em todos os momentos (da seleção no mestrado ao processo de conclusão) foi crucial para afastar meu inexorável pessimismo. A ela dedico este trabalho. Agradeço também à Vanda pelo carinho radiante e ao John pelo apoio à distância (e a ambos pelo auxílio com o inglês).

Encerro esta seção com um agradecimento a meus pais pela herança que deles recebi. Com meu pai, João, aprendi a valorizar altruísmo e solidariedade - não como mera retórica, mas enquanto ações e gestos que preenchem nossa vida. A despeito de sua famosa prolixidade, não me lembro de meu pai ensinando lições de moral, respeito ou tolerância para mim e meu irmãos; afinal, sua conduta generosa e humana em relação a todos que estão à sua volta sempre falou por si mesma.

É sempre pesaroso pensar sobre o pouco tempo em que pude conviver junto à minha mãe no "reino deste mundo". Foram apenas dezesseis anos em que tive ao meu lado a professora Eugenia. Neste pequeno período, porém, espero ter assimilado seus principais valores e anseios, os quais pretendo levar comigo ao longo de toda a vida: uma busca renitente pelo conhecimento e um mal-estar perene para com as injustiças que nos cercam.

Enfim, agradeço a meus pais por esta herança maravilhosa, que me permitiu ser um homem genuinamente rico. 


\section{RESUMO}

FIORE, DANILO C. Bases Sociais e Interiorização: O Predomínio Eleitoral do PSDB Paulista (1994-2014). Dissertação de Mestrado. FFLCH, Universidade de São Paulo. São Paulo, 2015.

Desde 1994, ininterruptamente o PSDB elege seus candidatos ao governo do Estado de São Paulo. Hegemonia eleitoral de tamanha duração- vitória em seis eleições consecutivas - não foi alcançada por nenhum outro partido em pleitos estaduais na história democrática brasileira recente. Tal feito é ainda mais relevante ao levarmos em conta a trajetória eleitoral paulista, historicamente associada a quadros partidários e resultados das urnas "surpreendentes". Assim, o objetivo desta pesquisa é identificar as bases sociais e territoriais do voto nos principais partidos do Estado de São Paulo, com ênfase no PSDB. Para tanto, utilizamos as seguintes variáveis: pesquisas eleitorais estratificadas por renda e escolaridade; tamanho dos municípios; nível de desenvolvimento médio das localidades (ao nível das zonas eleitorais e municípios) para duas regiões previamente estabelecidas - a Grande São Paulo e o interior. Identificamos que o partido tucano obtém apoio crescente na medida em que se elevam os índices socioeconômicos do eleitorado. O partido, porém, mantém um importante suporte entre os setores populares - sobretudo no interior do Estado. Por fim, ainda que obtenha penetração elevada em todos os municípios paulistas, o PSDB possui melhores resultados nas pequenas localidades. Ao final, discutimos estes achados à luz do panorama eleitoral, partidário e federativo no Brasil.

Palavras-chave: ESTUDOS ELEITORAIS; COMPORTAMENTO ELEITORAL; PARTIDOS POLÍTICOS; PSDB, POLÍTICA SUBNACIONAL. 


\begin{abstract}
FIORE, DANILO C. Social Bases and "Interiorization": The Electoral Prevalence of PSDB in São Paulo State (1994-2014). Master's Dissertation. FFLCH, Universidade de São Paulo. São Paulo, 2015.

Since 1994 until this date the Social Democrat Brazilian Party - PSDB has been continuously able to elect its candidates to the government of the state of São Paulo. Electoral hegemony for a very long time -victory in 6 consecutive elections, it has been unmatched by any other party in any State of the federation in the history of Brazilian Democracy. This is extraordinary especially if we take on account the electoral politics in the history of São Paulo where political parties and election results are usually full of surprises. Thus the objective of this research is to identify the social and territorial localization of voters according to the major parties present in the State of São Paulo, emphasizing the PSDB. In order to achieve this analysis we work with the following variables: electoral surveys stratified by income and level of education; size of the municipalities; average development of the localities (at the level of constituencies and municipalities) for two regions previously selected: the Great São Paulo and the inland. We identified a growing support to PSDB as the income rises. Nevertheless the party maintains an important level of support among the popular sectors - especially in the inland of the State of São Paulo. Finally, although it has obtained a high level of support in all the municipalities of the State of São Paulo, PSDB had its best results in the small localities. These data are discussed in the light of the political and electoral panorama in Brazil.
\end{abstract}

Keywords: ELECTORAL STUDIES; ELECTORAL BEHAVIOR; POLITICAL PARTIES; PSDB; SUBNATIONAL POLITICS. 


\section{Sumário}

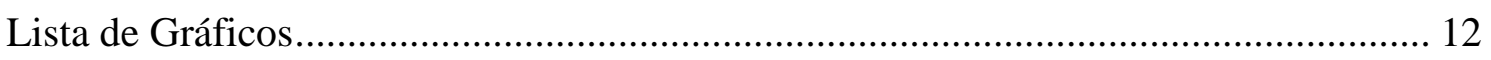

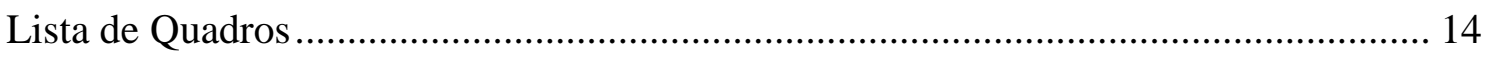

Lista de Abreviaturas ........................................................................................... 18

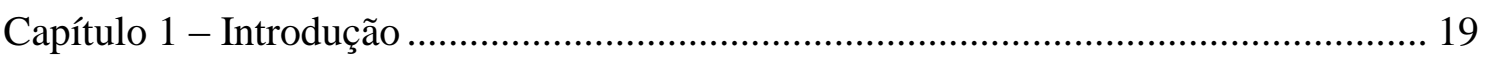

Primeiros Estudos: Classes Sociais no Regime de 1946 .......................................... 23

Outras Abordagens em um Novo Sistema (bi)Partidário ....................................... 25

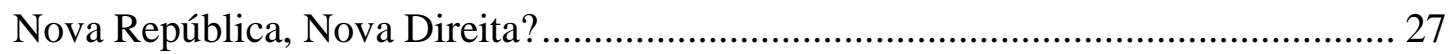

Consolidação Democrática: Enfim a Estabilidade?.................................................. 28

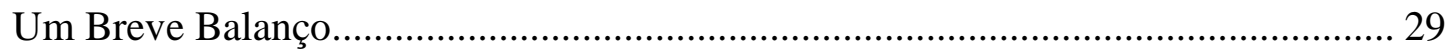

Capítulo 2 - Especificidades do Realinhamento Eleitoral em São Paulo ....................... 33

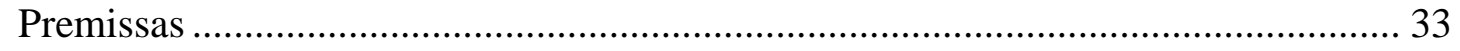

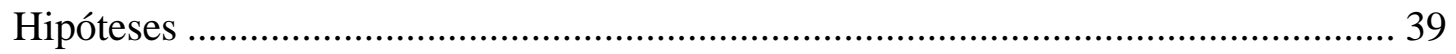

Antecedentes - As Eleições de 1990, 1994 e 1998 ................................................... 43

Eleições 2002: Continuidades ou Rupturas? ......................................................... 52

Eleições 2006 - Rupturas e Continuidades Não Esperadas ....................................... 60

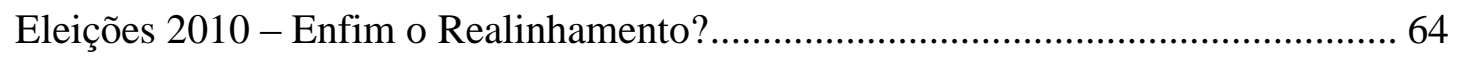

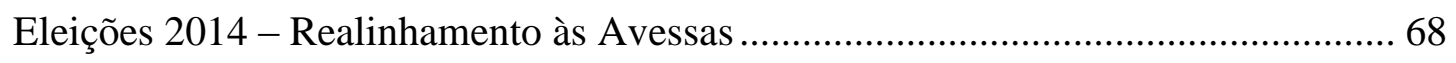

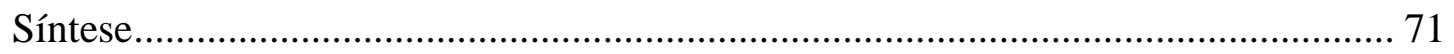

Capítulo 3 - Dinâmica Eleitoral no Território Paulista: Municípios e Variações

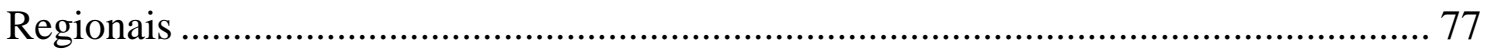

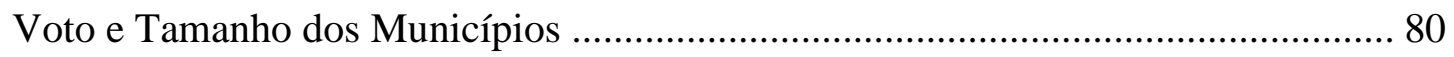

Grande São Paulo e Interior - Voto e Desenvolvimento Local ................................ 92

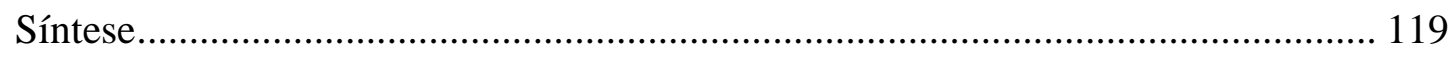

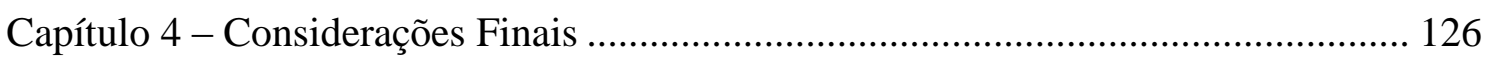

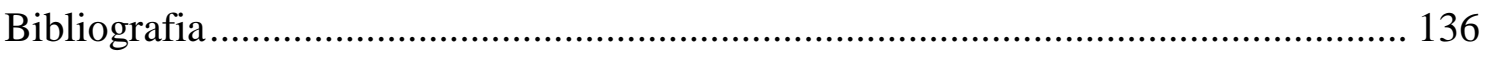

ANEXO I - Resultados Gerais - Eleições para Governador do Estado de São Paulo (1982-2014) - Principais Candidatos 
ANEXO II - Candidato à Prefeitura de São Paulo e ao Governo do Estado de São Paulo (1982-2014) - Principais Partidos ............................................................................. 145

ANEXO III - Coligações Partidárias (Principais Partidos) em São Paulo (1982-2014) 146 


\section{Lista de Gráficos}

Gráfico 1 - Distribuição de Arranjos Familiares por Classe de Rendimento Mensal 2013

Gráfico 2 - Distribuição de Pessoas (25 anos ou mais) por Grupos de Anos de Estudo (2013) 40

Gráfico 3- Percentual Médio de Votos Válidos por Decil de Escolaridade das Zonas Eleitorais ou Municípios - $1^{\circ}$ Turno - 2002. 56

Gráfico 4 - Percentual Médio de Votos Válidos por Decil de Escolaridade das Zonas Eleitorais e Municípios - $2^{\circ}$ Turno - 2002.

Gráfico 5- Percentual Médio de Votos Válidos por Decil de Escolaridade das Zonas Eleitorais $-1^{\circ}$ Turno - 2006 62

Gráfico 6- Percentual Médio de Votos Válidos por Decil de Escolaridade das Zonas Eleitorais $-1^{\circ}$ Turno -2010

Gráfico 7 Percentual Médio de Votos Válidos por Decil de Escolaridade das Zonas Eleitorais $-1^{\circ}$ Turno - 2014 68

Gráfico 8 - População dos Municípios Paulistas (2014). 88

Gráfico 9 - Percentual de Votos Válidos x Escolaridade Média das Zonas Eleitorais / Municípios (Grande São Paulo) - $1^{\circ}$ Turno 2002 - PSDB 97

Gráfico 10- Percentual de Votos Válidos x Escolaridade Média das Zonas Eleitorais / Municípios (Grande São Paulo) - $1^{\circ}$ Turno 2002 - PT. 98

Gráfico 11 - Percentual de Votos Válidos x Escolaridade Média das Zonas Eleitorais / Municípios (Grande São Paulo) - $1^{\circ}$ Turno 2002 - PDS/PP . 100

Gráfico 12 - Percentual de Votos Válidos x Escolaridade Média das Zonas Eleitorais / Municípios (Interior) - $1^{\circ}$ Turno 2002 - PSDB 101

Gráfico 13 - Percentual de Votos Válidos x Escolaridade Média das Zonas Eleitorais / Municípios (Interior) $-1^{\circ}$ Turno $2002-\mathrm{PT}$. 102

Gráfico 14 - Percentual de Votos Válidos x Escolaridade Média das Zonas Eleitorais / Municípios (Interior) - $1^{\circ}$ Turno 2002 - PDS/PP 103

Gráfico 15 - Percentual de Votos Válidos x Escolaridade Média das Zonas Eleitorais / Municípios (Grande SP) - $2^{\circ}$ Turno 2002 - PSDB e PT. 104

Gráfico 16 - Percentual de Votos Válidos x Escolaridade Média das Zonas Eleitorais / Municípios (Interior) - 2o Turno 2002 - PSDB e PT. 105 
Gráfico 17 - Percentual de Votos Válidos x Escolaridade Média das Zonas Eleitorais / Municípios (Grande São Paulo) - $1^{\circ}$ Turno 2006 - PSDB e PT .

Gráfico 18 - Percentual de Votos Válidos x Escolaridade Média das Zonas Eleitorais / Municípios (Interior) - $1^{\circ}$ Turno 2006 - PSDB e PT.

Gráfico 19 - Percentual de Votos Válidos x Escolaridade Média das Zonas Eleitorais / Municípios (Grande São Paulo) - 1 Turno 2010 - PSDB e PT .

Gráfico 20 - Percentual de Votos Válidos x Escolaridade Média das Zonas Eleitorais / Municípios (Interior) - $1^{\circ}$ Turno 2010 - PSDB e PT.

Gráfico 21 - Percentual de Votos Válidos x Escolaridade Média das Zonas Eleitorais / Municípios (Grande São Paulo) - $1^{\circ}$ Turno 2014 - PSDB e PT.

Gráfico 22 - Percentual de Votos Válidos x Escolaridade Média das Zonas Eleitorais / Municípios (Grande São Paulo) - $1^{\circ}$ Turno 2014 - PMDB 116

Gráfico 23 - Percentual de Votos Válidos x Escolaridade Média das Zonas Eleitorais / Municípios (Interior) - $1^{\circ}$ Turno 2014 - PSDB e PT.

Gráfico 24 - Percentual de Votos Válidos x Escolaridade Média das Zonas Eleitorais / Municípios (Interior) - $1^{\circ}$ Turno 2014 - PMDB 118

Gráfico 25 - Votos Válidos dos Partidos - Eleições para Governador de São Paulo (1982-2014) - $1^{\circ}$ Turno 130 


\section{Lista de Quadros}

Quadro 1 - Votos Válidos nas Eleições Presidenciais de 2014 (1º Turno) - Comparação MG x Brasil

Quadro 2 - Votos Válidos nas Eleições Presidenciais de 2014 (1º Turno)- Comparação MA x SP x Brasil....

Quadro 3- Preferência dos Eleitores por Renda Familiar Mensal - Eleições para Governador (1990)

Quadro 4 - Preferência dos Eleitores por Grau de Escolaridade - Eleições para

Governador (1990) 45

Quadro 5- Preferência dos Eleitores por Renda Familiar Mensal - Eleições para Governador (1994) - $1^{\circ}$ Turno 46

Quadro 6- Preferência dos Eleitores por Grau de Escolaridade - Eleições para Governador (1994) - $1^{\circ}$ Turno 47

Quadro 7- Preferência dos Eleitores por Renda Familiar Mensal - Eleições para Governador (1994) - 20 Turno . 48

Quadro 8- Preferência dos Eleitores por Grau de Escolaridade - Eleições para Governador (1994) - $2^{\circ}$ Turno 49

Quadro 9- Preferência dos Eleitores por Grau de Escolaridade - Eleições para Governador (1998) - $1^{\circ}$ Turno ..... 50

Quadro 10 - Preferência dos Eleitores por Renda Familiar Mensal - Eleições para Governador (1998) - $2^{\circ}$ Turno 51

Quadro 11- Preferência dos Eleitores por Grau de Escolaridade - Eleições para Governador (1998) - $2^{\circ}$ Turno . 51

Quadro 12- Preferência dos Eleitores por Renda Familiar Mensal - Eleições para Presidente $(2002)-1^{\circ}$ Turno

Quadro 13- Preferência dos Eleitores por Renda Familiar Mensal - Eleições para Governador (2002) - $1^{\circ}$ Turno

Quadro 14 - Preferência dos Eleitores por Grau de Escolaridade - Eleições para Governador (2002) - $1^{\circ}$ Turno 57

Quadro 15 - Preferência dos Eleitores por Renda Familiar Mensal - Eleições para Governador (2002) - $2^{\circ}$ Turno

Quadro 16- Preferência dos Eleitores por Grau de Escolaridade - Eleições para Governador (2002) - $2^{\circ}$ Turno 
Quadro 17- Preferência dos Eleitores por Renda Familiar Mensal - Eleições para Presidente (2006) $-1^{\circ}$ Turno

Quadro 18- Preferência dos Eleitores por Renda Familiar Mensal - Eleições para Governador (2006) $-1^{\circ}$ Turno

Quadro 19- Preferência dos Eleitores por Grau de Escolaridade - Eleições para Governador (2006) $-1^{\circ}$ Turno

Quadro 20- Preferência dos Eleitores por Renda Familiar Mensal - Eleições para Presidente (2010) $-1^{\circ}$ Turno 66

Quadro 21- Preferência dos Eleitores por Grau de Escolaridade - Eleições para Presidente (2010) $-1^{\circ}$ Turno 66

Quadro 22- Preferência dos Eleitores por Renda Familiar Mensal - Eleições para Governador (2010) - $1^{\circ}$ Turno

Quadro 23 - Preferência dos Eleitores por Grau de Escolaridade - Eleições para Governador (2010) - $1^{\circ}$ Turno

Quadro 24- Preferência dos Eleitores por Renda Familiar Mensal - Eleições para Governador (2014) - $1^{\circ}$ Turno 69

Quadro 25- Preferência dos Eleitores por Grau de Escolaridade - Eleições para Governador (2014) - $1^{\circ}$ Turno 70

Quadro 26- Preferência dos Eleitores por Renda Familiar Mensal - Eleições para Presidente (2014) $-1^{\circ}$ Turno 70

Quadro 27- Preferência dos Eleitores por Grau de Escolaridade - Eleições para Presidente (2014) $-1^{\circ}$ Turno 71

Quadro 28- População dos Municípios Paulistas (2014).... 81

Quadro 29 - Percentual de Votos Válidos por Grupo de Municípios (1994-2014) PSDB $-1^{\circ}$ Turno

Quadro 30 - Percentual de Votos Válidos por Grupo de Municípios (1994-2014) - PT $1^{\circ}$ Turno

Quadro 31 - Percentual de Votos Válidos por Grupo de Municípios (1994-2014) PMDB $-1^{\circ}$ Turno.

Quadro 32 - Percentual de Votos Válidos por Grupo de Municípios (1994-2014) PDS/PP $-1^{\circ}$ Turno 85

Quadro 33 - Percentual de Votos Válidos por Grupo de Municípios (1994-2014) - PDT $-1^{\circ}$ Turno 86 
Quadro 34 - Correlações (R de Pearson) entre percentual de votos válidos e população dos municípios paulistas - Eleições para governador ( $1^{\circ}$ Turno).

Quadro 35 - Distribuição Populacional no Estado de São Paulo (Milhões de Habitantes e Percentual)

Quadro 36 - Porcentagem de Votos Válidos dos Principais Partidos nas Eleições para o Governo do Estado de São Paulo - Grande São Paulo e Interior (1994-2014). 95

Quadro 37- Correlações ( $\mathrm{R}$ de Pearson) entre percentual de votos válidos e Escolaridade Média das Zonas Eleitorais / Municípios (Grande São Paulo) - $1^{\circ}$ Turno 2002 - PSDB 98

Quadro 38- Correlações ( $\mathrm{R}$ de Pearson) entre percentual de votos válidos e Escolaridade Média das Zonas Eleitorais / Municípios (Grande São Paulo) - $1^{\circ}$ Turno $2002-\mathrm{PT}$

Quadro 39 - Correlações ( $\mathrm{R}$ de Pearson) entre percentual de votos válidos e Escolaridade Média das Zonas Eleitorais / Municípios (Grande São Paulo) - $1^{\circ}$ Turno 2002 - PDS/PP 100

Quadro 40 - Correlações ( $\mathrm{R}$ de Pearson) entre percentual de votos válidos e Escolaridade Média das Zonas Eleitorais / Municípios (Interior) - $1^{\circ}$ Turno 2002 PSDB 101

Quadro 41 - Correlações ( $\mathrm{R}$ de Pearson) entre percentual de votos válidos $\mathrm{e}$ Escolaridade Média das Zonas Eleitorais / Municípios (Interior) - $1^{\circ}$ Turno 2002 - PT

Quadro 42 - Correlações ( $\mathrm{R}$ de Pearson) entre percentual de votos válidos $\mathrm{e}$ Escolaridade Média das Zonas Eleitorais / Municípios (Interior) - $1^{\mathrm{o}}$ Turno 2002 PDS/PP

Quadro 43 - Correlações ( $\mathrm{R}$ de Pearson) entre percentual de votos válidos e Escolaridade Média das Zonas Eleitorais / Municípios (Grande SP) - 2º Turno 2002 PSDB e PT.

Quadro 44 - Correlações ( $\mathrm{R}$ de Pearson) entre percentual de votos válidos e Escolaridade Média das Zonas Eleitorais / Municípios (Interior) - 2 ${ }^{\circ}$ Turno 2002 PSDB e PT.

Quadro 45- Correlações ( $\mathrm{R}$ de Pearson) entre percentual de votos válidos e

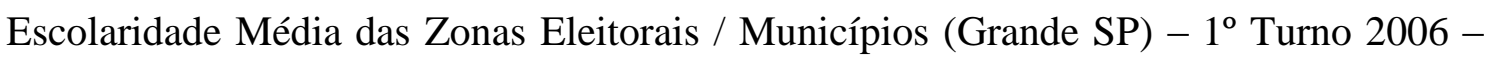
PSDB e PT.

Quadro 46 - Correlações ( $\mathrm{R}$ de Pearson) entre percentual de votos válidos e Escolaridade Média das Zonas Eleitorais / Municípios (Interior) - $1^{\circ}$ Turno 2006 PSDB e PT. 
Quadro 47- Correlações ( $\mathrm{R}$ de Pearson) entre percentual de votos válidos e

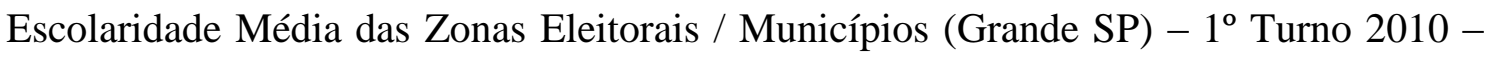
PSDB e PT.

Quadro 48 - Correlações ( $\mathrm{R}$ de Pearson) entre percentual de votos válidos e Escolaridade Média das Zonas Eleitorais / Municípios (Interior) - $1^{\circ}$ Turno 2010 PSDB e PT

Quadro 49 - Correlações ( $\mathrm{R}$ de Pearson) entre percentual de votos válidos e Escolaridade Média das Zonas Eleitorais / Municípios (Grande SP) - $1^{\circ}$ Turno 2014 PSDB e PT.

Quadro 50 - Correlações ( $\mathrm{R}$ de Pearson) entre percentual de votos válidos e Escolaridade Média das Zonas Eleitorais / Municípios (Grande SP) - $1^{\circ}$ Turno 2014 PMDB 116

Quadro 51 - Correlações ( $\mathrm{R}$ de Pearson) entre percentual de votos válidos e Escolaridade Média das Zonas Eleitorais / Municípios (Interior) - $1^{\circ}$ Turno 2014 PSDB e PT.

Quadro 52 - Correlações ( $\mathrm{R}$ de Pearson) entre percentual de votos válidos e Escolaridade Média das Zonas Eleitorais / Municípios (Interior) - $1^{\circ}$ Turno 2014 PMDB

Quadro 53 - Votação Somada dos Dois Primeiros Colocados no Primeiro Turno em SP (1990-2014) 


\section{Lista de Abreviaturas}

Fundação SEADE - Fundação Sistema Estadual de Análise de Dados

IBGE - Instituto Brasileiro de Geografia e Estatística

PCB - Partido Comunista Brasileiro

PDS / PP - Partido Democrático Social / Partido Progressista

PDT - Partido Democrático Trabalhista

PFL / DEM - Partido da Frente Liberal / Democratas

PMDB - Partido do Movimento Democrático Brasileiro

PSB - Partido Socialista Brasileiro

PSD - Partido Social Democrático

PSDB - Partido da Social Democracia Brasileira

PSP - Partido Social Progressista

PT - Partido dos Trabalhadores

PTB - Partido Trabalhista Brasileiro

TSE - Tribunal Superior Eleitoral

TRE - Tribunal Regional Eleitoral

UDN - União Democrática Nacional 


\section{Capítulo 1 - Introdução}

Em uma declaração famosa nos anos 1990, o então Ministro das Comunicações do Governo Fernando Henrique Cardoso, Sérgio Mota (1940-1998), previu que o projeto de poder nacional do Partido da Social Democracia Brasileira (PSDB), inaugurado em 1994 sob os auspícios do Plano Real, teria a duração de vinte anos consecutivos. Ainda que no plano federal o vaticínio não tenha se concretizado, no Estado de São Paulo o PSDB teve êxito análogo: desde 1994, o partido elegeu todos os seus candidatos para o cargo de governador do Estado.

A permanência no governo, desde a eleição de Mario Covas ${ }^{1}$ em 1994 até a reeleição de Geraldo Alckmin no pleito de 2014, se configura como fato inédito na história política democrática brasileira recente. Desde o período de redemocratização (que, nos pleitos estaduais brasileiros, inicia-se em 1982), não houve caso de continuidade política tão duradoura quanto a do PSDB no Estado de São Paulo. Mesmo em Estados com lideranças tradicionais e grupos políticos de força regional expressiva, o feito de se vencer consecutivamente seis eleições não foi conseguido até o momento ${ }^{2}$.

As vitórias do PSDB em seis das nove eleições estaduais realizadas pósredemocratização tornam-se ainda mais relevantes se levarmos em conta a importância econômica, demográfica e eleitoral do Estado de São Paulo, o mais rico e populoso da Federação. Ademais, o Estado paulista é o berço dos dois partidos que polarizam as eleições presidenciais desde 1994 - PSDB e PT - e local em que dois ex-presidentes da República do período recente construíram suas trajetórias políticas: Fernando Henrique Cardoso (PSDB) e Luis Inácio Lula da Silva (PT).

Tentar analisar este tema é tarefa de grande complexidade, dada a impossibilidade de se "explicar" um fenômeno político desta ordem. Abordagens

\footnotetext{
${ }^{1}$ Vale destacar que André Franco Montoro (1982), Orestes Quércia (1986) e Luiz Antônio Fleury Filho (1990) foram eleitos pelo Partido do Movimento Democrático Brasileiro (PMDB), agremiação da qual o PSDB se formou a partir de uma dissidência em 1988 - sendo Montoro (1916-1999), inclusive, um de seus fundadores e principais líderes. Figuras de destaque nos governos Quércia e Fleury, como o atual Senador Aloysio Nunes Ferreira (PSDB-SP) e o ex-governador Alberto Goldman (vice, assumiu em 2010), migraram posteriormente do PMDB para o PSDB. Ainda que fuja ao escopo do trabalho e que não se pretenda afirmar que a hegemonia eleitoral do mesmo grupo político já passa dos 30 anos, os legados históricos de continuidade merecem ser mencionados. Sobre pleitos paulistas anteriores a 1994, ver COSTA \& FERRARI (1989). Sobre a fundação e o percurso inicial do PSDB, ver ROMA (2002).

2 Como exemplo, destaquem-se dois casos: O "carlismo", grupo político do ex-senador Antonio Carlos Magalhães (1927-2007) ligado ao então PFL (atual DEM), elegeu quatro governadores consecutivos (1990 a 2002) na Bahia, sendo, contudo, derrotado em 2006. No Acre, o PT dos irmãos Jorge e Tião Vianna iniciou sua hegemonia eleitoral em 1998 e ocupa a cadeira do governador pela quinta vez consecutiva. Sobre a transição baiana, ver BORGES (2010).
} 
teóricas e metodológicas diversas podem ser acionadas para analisar a prevalência de determinado partido em um determinado contexto eleitoral: o desempenho dos governantes, a formação de preferência dos eleitores, o contexto partidário e eleitoral, entre muitos outros. De nossa parte, optamos por analisar o caso paulista, primeiramente, a partir de sua inserção na dinâmica de interação entre partidos e bases sociais no Brasil recente.

É destacada na literatura a importância do pleito nacional de 2006 para o panorama político e eleitoral brasileiro recente. Com efeito, diversos trabalhos (os quais trataremos em detalhes no capítulo 2) apontam para importantes modificações nas bases sociais dos principais partidos brasileiros nestas eleições (HUNTER \& POWER, 2007; NICOLAU \& PEIXOTO, 2007; ZUCCO, 2008; SINGER, 2012; SOARES \& TERRON, 2010; LIMONGI \& GUARNIERI, 2014). Em nível nacional, o PT, que anteriormente obtivera seus principais redutos eleitorais em torno das classes médias do centro-sul do país, passa a contar com expressiva votação nas localidades e estratos com menor nível de desenvolvimento econômico, sobretudo na região Nordeste do país. De maneira inversa e simétrica, seu principal adversário, o PSDB, que obtivera nos pleitos em que venceu (1994 e 1998) penetração relativamente homogênea ao longo do território nacional, passa a concentrar seus principais nichos de apoio nas localidades e estratos mais desenvolvidos do eleitorado (localizados, sobremaneira, no Centro-Sul do Brasil).

Neste sentido, indagamos se este mesmo padrão repetiu-se no Estado de São Paulo em um contexto eleitoral distinto (as eleições para o governo estadual). Procuraremos verificar, assim, se o fenômeno de realinhamento eleitoral - a saber, as modificações de bases sociais dos principais partidos brasileiros -, ocorrido em nível nacional entre os pleitos de 2002 e 2006 (e cujas características descritas no parágrafo anterior persistem desde então) ${ }^{3}$ teria acontecido também em nível subnacional a partir de 2006.

A hipótese é de que o realinhamento teve aspectos singulares no Estado de São Paulo: devido a suas características socioeconômicas - maior nível de desenvolvimento econômico e proporção maior de eleitores de estratos mais elevados de escolaridade e renda -, o Estado paulista contaria com base social mais aderente ao PSDB. São

\footnotetext{
${ }^{3} \mathrm{O}$ conceito de realinhamento eleitoral e sua utilização para o caso brasileiro é motivo de controvérsia. Conforme mencionado, trataremos a questão em pormenores no capítulo 2.
} 
indícios dessa hipótese a vitória esmagadora do partido tucano no pleito de 2006 (ressalte-se, primeira vez na história em que a eleição paulista não teve segundo turno) e suas contínuas vitórias (ressalte-se novamente, todas em primeiro turno) nos pleitos seguintes.

De forma a testar esta hipótese, procuraremos identificar, no capítulo 2, as bases sociais dos principais partidos nas eleições para o governo do Estado de São Paulo entre 1994 e 2014 a partir dos resultados de pesquisas eleitorais amostrais realizadas próximo ao dia da votação, estratificadas por escolaridade e renda. De forma complementar, observaremos também a distribuição de votos nos principais partidos conjugada com um índice de desenvolvimento médio das localidades eleitorais (zonas eleitorais e municípios) elaborado a partir das informações de escolaridade fornecidas pelo Tribunal Superior Eleitoral. A utilização destes dois elementos - a intenção de voto e os resultados eleitorais propriamente ditos - tem por objetivo identificar de maneira mais precisa as bases sociais dos partidos no Estado de São Paulo. Esta também é a razão pela qual utilizaremos pesquisas estratificadas por escolaridade e por renda (dois critérios relevantes para diferenciação socioeconômica dos eleitores).

Conforme veremos nas seções seguintes deste capítulo, a literatura referente a estudos eleitorais aponta a importância de bases sociais dos partidos no Estado de São Paulo para explicar o voto. Dos primeiros estudos na década de 1950 e 1960, passando pela análise do regime bipartidário da Ditadura nos anos 1970 aos pleitos pósredemocratização a partir dos anos 1980, diversos autores procuraram identificar as clivagens de suporte aos principais partidos em termos da distribuição socioeconômica do eleitorado.

Para além destes elementos sociais, também as variações inter-regionais e a distinção demográfica entre os municípios (sobretudo em relação ao tamanho populacional) foi acionada na literatura para identificar os perfis de votação dos principais partidos no Estado de São Paulo.

$\mathrm{Na}$ literatura, são apontadas clivagens significativas entre os principais partidos no Estado de São Paulo quando analisadas as variáveis citadas acima. Apresentaremos nas seções seguintes os principais estudos referentes a distinções entre os partidos quando analisados aspectos de inserção regional e tamanho dos municípios. 
Logo, para além das distinções entre padrões socioeconômicos dos eleitores, procuraremos verificar se a distribuição de votos entre os principais partidos (com ênfase, uma vez mais, no PSDB) se dá de maneira uniforme ao longo do território primeiramente em termos de magnitude populacional das cidades paulistas. Nossa hipótese é de que o PSDB, em consonância com o padrão apontado pela literatura, possui sua principal base de apoio no interior do Estado e, portanto, penetração expressiva nos pequenos municípios.

Além desta variável (a saber, tamanho dos municípios), utilizamos também distinção entre dois territórios previamente definidos para análise de bases sociais dos partidos - a Grande São Paulo e o Interior. A escolha por este recorte territorial será explicitada no capítulo 3 e tem por objetivo verificar se há distinções de monta no desempenho dos partidos quando analisadas regiões distintas. Utilizaremos novamente os resultados eleitorais do período conjugados com informações de escolaridade média dos territórios eleitorais (zonas ou municípios). O objetivo é verificar se as clivagens socioeconômicas do eleitorado - as quais analisaremos no capítulo 2 seguinte apresentam também características regionais. Ou seja, testar se, nas duas unidades de análise previamente selecionadas (a Grande São Paulo e o Interior) é semelhante a distribuição de votos entre os principais partidos de acordo com o índice de desenvolvimento médio das localidades.

Haveria, nas eleições para o governo do Estado de São Paulo, uma distribuição de preferência dos eleitores em termos socioeconômicos semelhante à encontrada em nível nacional após 2006? Ademais, tal distribuição se daria de modo homogêneo ao longo do território paulista ou haveria diferenciações importantes se levados em conta a distinção entre duas regiões do Estado - a Grande São Paulo e o interior?

Tentar responder a estas indagações é o objetivo desta dissertação, dividida em três capítulos. Neste primeiro capítulo, além desta introdução, elaboramos um panorama sobre a literatura do comportamento eleitoral no Estado São Paulo e situamos a discussão teórica e metodológica em que se insere esta pesquisa.

No capítulo 2, conforme citado, analisaremos o perfil socioeconômico do eleitorado dos principais partidos em São Paulo nas eleições para o governo do Estado, de 1994 a 2014 (com ênfase maior nos pleitos realizados após 2002, pelas razões expostas acima). No capítulo 3, analisaremos a distribuição de votos dos partidos no mesmo recorte temporal a partir de duas variáveis: o tamanho dos municípios e a 
localização do território eleitoral em unidades geográficas específicas (a Grande São Paulo e o interior do Estado). Conforme mencionamos acima, esta última variável será analisada conjuntamente com o índice de desenvolvimento médio das localidades eleitorais utilizado no capítulo anterior. Ao final, procuraremos sintetizar, conjugar e compreender os resultados encontrados em ambos os capítulos.

A conclusão do trabalho traz um sumário e uma interpretação dos principais dados empíricos levantados nesta pesquisa. Dada a complexidade do tema já mencionada, apontaremos para novos caminhos de investigação que poderão ser traçados para elucidação deste importante fenômeno da política brasileira: o predomínio eleitoral sem precedentes de um dos principais partidos brasileiro, o PSDB, no Estado mais rico e populoso da Federação.

\section{Primeiros Estudos: Classes Sociais no Regime de 1946}

Os primeiros estudos sobre o comportamento eleitoral no Estado de São Paulo são da década de 1950. Fortemente influenciados pela sociologia política, enfatizam a relação entre o voto e a posição social (em termos, sobretudo, de classe) dos eleitores.

O trabalho pioneiro de Aziz Simão (1956) identificou o padrão de votação dos bairros operários da capital nas eleições para prefeito de 1947 e 1953. Os dados levantados levaram o autor a concluir que o então Partido Comunista Brasileiro (PCB) possuía bases eleitorais significativas nos estratos operários; porém, o fato de ter sido colocado na ilegalidade em 1947 teria deixado "órfãos" seus eleitores, o que tornou a aliança PTB-PSP (este último, o partido do líder Adhemar de Barros) depositária do apoio deste segmento. Interessante notar que o autor apresenta uma distinção entre os dois blocos (a saber, PCB e PTB/PSP), sendo o primeiro um voto operário "consciente" e o segundo uma escolha carismático-paternalista, oriunda sobretudo da gratidão com relação à legislação trabalhista aprovada à época.

Vale destacar, neste ponto, dois fatores relevantes do panorama político paulista no Regime de 1946. Em primeiro lugar, a força de candidatos definidos como pouco ideológicos, sem bases partidárias sólidas e cuja força política repousava em forte conteúdo carismático - ou seja, a quintessência do que se convencionou denominar de

\footnotetext{
${ }^{4} \mathrm{O}$ autor não qualifica esta observação, mas pode-se inferir que esteja relacionada a um eventual componente classista presente no voto do operiado.
} 
"populistas"; ; em segundo, a fraqueza, nas eleições paulistas, dos partidos mais fortes no cenário nacional (a saber, PTB, UDN e PSD).

Com relação à força do populismo em São Paulo, o principal teórico do conceito, Francisco Weffort (1965), analisou a eleição de 1962 (disputada entre Adhemar e Jânio e vencida pelo primeiro). O autor tenta entender uma eleição que, superficialmente, seria o confronto de dois líderes sem conteúdo ideológico algum, mera disputa de carisma e retórica. Analisando dados eleitorais, além de uma pesquisa em formato survey e a campanha dos dois candidatos, Weffort encontrou bases sociais distintas de apoio a cada um. Adhemar vence no interior do Estado, enquanto Jânio obteve maior apoio nos aglomerados urbanos e nas regiões com maior quantidade de operários. Para Weffort, há formas de identificação distintas, mas possuem ambas substrato de classe. Utilizando-se dos conceitos desenvolvidos por Weber sobre os tipos de dominação legítima e as categorias sociológicas clássicas de Marx, Weffort elabora uma dupla interpretação para os resultados.

$\mathrm{O}$ ademarismo seria formado primordialmente por pequenos proprietários e setores do lúmpen. Estes estratos tenderiam ao conservadorismo pelo temor frente à ascensão de novos atores sociais e sua tendência à decadência com o avanço da modernização. O discurso patriarcal de Adhemar (uma liderança amorosa e segura em tempos de incerteza) se conectaria com o anseio por um Estado assistencial (ainda que discricionário), capaz de recuperar o passado idílico de outrora e aplacar o pessimismo destes segmentos.

Já as fileiras janistas seriam formadas majoritariamente pelos setores assalariados em ascensão com a industrialização acelerada do Estado. Para estes, o discurso carismático de cunho individualista e a ênfase moralista (combate à corrupção) traduziria a escolha por um Estado justo e republicano, que não impedisse o progresso dos ascendentes. Assim, o eleitorado de Jânio teria um viés progressista e modernizador incipiente, ao passo que o de Adhemar seria entusiasta da "pré-modernidade".

Resta ainda, porém, a questão da fraqueza dos grandes partidos nacionais em São Paulo - sobretudo do PTB, cuja base nos sindicatos e meios operários torna

\footnotetext{
${ }^{5}$ Uma frase sintetiza a visão negativa atribuída aos líderes ditos então "populistas": "Evite por todos meios obrigar o povo a refletir. (...) Dê-lhe sempre razão. Prometa-lhe tudo o que ele pede e abrace-o o quanto puder (...)”. (WEFFORT; 1965, p. 42). A frase é de Plínio Barreto, quadro histórico da União Democrática Nacional (UDN), e foi proferida no contexto da derrota esmagadora de seu partido para o PSP de Adhemar de Barros na eleição para governador de São Paulo de 1947.
} 
paradoxal a pequena presença no Estado mais industrializado da Federação. Já em períodos posteriores (anos 1970 e 1980), dois autores analisaram este aparente “paradoxo". Para Fernando Henrique Cardoso (1978), tal fraqueza seria fruto da própria luta interna do partido, cujo controle central pelas lideranças dependia da atrofia do diretório do maior e mais industrializado Estado. É por essa razão (a saber, a fraqueza do principal partido trabalhista e a fragmentação de outras agremiações menores de mesma linha), segundo Cardoso, que lideranças como Jânio Quadros conseguiram capitanear o voto das camadas populares.

Maria Vitória Benevides (1989) fez análise semelhante, mas agrega outros termos ao trabalho de Cardoso (op. cit.). Segundo a autora, se por um lado é fato que o Diretório Nacional do PTB intervinha constantemente na seção paulista e não movia grandes esforços para a consolidação do partido neste Estado, por outro há que se verificar se a dinâmica interna da legenda em São Paulo também não teria contribuído para sua fraqueza. Para a autora, o comportamento errático do partido em termos eleitorais (que, ao longo de todo o período, compôs alianças de todos os tipos: apoiou Adhemar em 1947, Jânio em 1954, Adhemar novamente em 1958 e a UDN - grande adversária no plano nacional, diga-se - em 1962) e sua ligação clientelística com sindicatos atrelados ao aparelho estatal impossibilitaram o enraizamento do partido como representante legítimo das classes populares.

\section{Outras Abordagens em um Novo Sistema (bi)Partidário}

O Golpe de 1964 significou o fim do Regime de 1946 e do sistema partidário vigente, com a reconfiguração do quadro político a partir da clivagem bipartidária entre a Arena (o partido do Regime) e o MDB (o partido de oposição) a partir de 1966. Em um contexto de autoritarismo, censura, repressão armada a movimentos de resistência, tortura a dissidentes políticos e cassação de quadros importantes de oposição ao Regime, não causou estranheza a vitória acachapante da Arena no pleito de $1970^{6}$. Esperava-se, assim, que as eleições de 1974 repetissem a mesma escrita. A apuração dos resultados mostrou, porém, uma vitória expressiva do MDB. No caso da eleição para o

\footnotetext{
${ }^{6}$ Dados tabulados por Kinzo (1988; p. 76) para a eleição de 1970 demonstram a supremacia da ARENA, que conquistou 48,6\% dos votos totais para a Câmara dos Deputados em SP ante 16,7\% do MDB. Destaque-se nesta eleição o número expressivo de votos nulos e brancos (34,6\% do total). Vale lembrar também que não havia eleições para presidente da República, governadores, capitais e municípios declarados de interesse de segurança nacional. Assim, as eleições para o senado tornaram-se praticamente os únicos confrontos majoritários relevantes. Para uma análise de votações para o executivo ao nível local em São Paulo, ver a análise de Bolívar Lamounier (1978) acerca do município de Presidente Prudente.
} 
representante de São Paulo no Senado, um quadro experiente da ARENA (o exgovernador Carvalho Pinto) teve fragorosa derrota ante um jovem político do MDB, Orestes Quércia (vitorioso com $73 \%$ dos votos válidos, ante $27 \%$ de Carvalho Pinto ${ }^{7}$ ).

No trabalho supracitado de Cardoso (idem), o mesmo identifica mais continuidade do que ruptura nesta vitória paulista da oposição. A extinção do sistema pluripartidário e a instauração do sistema bipartidário em 1966 não teriam significado uma reconfiguração completa do sistema político, uma vez que o partido de oposição ao regime (o MDB) manteve um expressivo apoio das camadas urbanas mais pobres da população por representar, ainda que maneira tênue, aspirações sociais e críticas ao regime vigente.

Por essa interpretação, a vitória da oposição em 1974 - inesperada à época devido ao controle da máquina pela situação e ao bom momento econômico do país torna-se menos surpreendente. Assim, a votação robusta do MDB nas camadas populares seria prova da existência da relação, ainda que tênue, entre os partidos políticos e os estratos de classe.

Em estudo sócio-demográfico e geográfico da distribuição de votações no Estado de São Paulo, Vilmar Faria (1978) também encontrou clivagens significativas entre os dois partidos do Regime Militar. A partir de testes estatísticos e de análises espaciais, o autor identificou perfis distintos de apoio às agremiações: enquanto a Arena mantinha suporte nas regiões menos desenvolvidas e urbanizadas do Estado, o partido de oposição possuía apoio significativo nas regiões mais desenvolvidas do eixo metropolitano paulista (Grande São Paulo, Campinas e Vale do Paraíba). O desenvolvimento econômico e social acelerado do período (e ainda mais acentuado no Estado de São Paulo) teria criado contexto favorável ao MDB, que, segundo o autor, “(...) venceu as eleições em áreas representativas do Brasil moderno” (FARIA; op.cit: 236).

Já Bolívar Lamounier (1980), ao analisar os pleitos de 1970 a 1978 na cidade de São Paulo, interpretou o crescimento eleitoral do MDB de maneira distinta, fruto da consolidação da imagem da sigla como o partido "do povo" ou "contra o governo". Nesse sentido, o fato do partido não poder assumir o governo (e, portanto, ser incapaz de responder às demandas substantivas dos eleitores) era menos relevante do que sua

\footnotetext{
${ }^{7}$ http://www.seade.gov.br/produtos/moveleitoral/index.php (acesso em 10 de Dezembro de 2013).
} 
capacidade de catalisar uma identificação partidária difusa entre diferentes setores da população (até mesmo nos estratos de menor escolaridade, comumente associados a um voto clientelístico ou personalista). Neste momento o MDB torna-se a "sigla mágica", ao galvanizar o apoio dos setores populares menos por uma questão social ou de classe e mais pela identificação com o eleitorado menos escolarizado da população.

Ao analisar as eleições paulistas entre 1974 e 1986 (ou seja, já adentrando no momento posterior à reconfiguração do sistema partidário de 1979, quando o bipartidarismo dá lugar a um sistema multipartidário), Maria Teresa Sadek (1989) observou um processo de realinhamento eleitoral: o PMDB (ex-MDB), que tivera maior apoio nos municípios mais industrializados e urbanizados, passa por uma progressiva "interiorização", com maior apoio nos pequenos municípios e decréscimo de votos na Grande São Paulo. A autora levanta as seguintes hipóteses para este fenômeno: os efeitos da competição pluripartidária; o fato do partido ter se tornado situação (no Estado e na União), o que muda a percepção do eleitorado sobre sua atuação; e a organização do partido no interior, já consolidada frente aos novos partidos.

\section{Nova República, Nova Direita?}

A longa transição democrática (que, em termos eleitorais, inicia-se com as eleições diretas para governador em 1982) traz em seu bojo a criação de um novo sistema partidário. Conforme mencionado, o MDB transforma-se em PMDB, a ARENA em PDS e novos partidos surgem em cena. À esquerda, o surgimento do PT traz para a arena eleitoral um novo competidor com discurso fortemente classista e coloca em questão a viabilidade popular da então "sigla mágica" peemedebista.

Para além da progressiva interiorização do PMDB (verificada já no pleito de 1982, conforme SADEK (op. cit.)), os pleitos subsequentes das décadas de 1980 e 1990 demonstraram a viabilidade eleitoral da direita, representada principalmente pelo candidato Paulo Maluf (PDS) ${ }^{8}$ - ora candidato a governador do Estado, ora a prefeito da capital. Neste cenário, a despeito da vitória na eleição da capital em 1988, com Luiza Erundina (em pleito apenas com primeiro turno, ressalte-se), o PT teve grandes dificuldades para colocar-se como competidor viável entre os estratos mais populares ${ }^{9}$.

\footnotetext{
${ }^{8}$ Destaque-se já em 1985 a vitória também surpreendente de Jânio Quadros (PTB) sobre Fernando Henrique Cardoso (PMDB) na disputa para a prefeitura da capital.

9 Ao analisar os resultados das eleições de 1986, em que o PT ficou em um distante quarto lugar, Francisco Weffort (à época militante dos mais destacados do PT) cunhou uma expressão que sintetizava
} 
Analisando os resultados das eleições municipais e estaduais na cidade de São Paulo nos anos de 1988 e 1990, Pierucci e Lima (1992) identificaram uma tendência de aumento do voto em Maluf em bairros de alta renda e escolaridade. O voto urbano "popular" de direita ${ }^{10}$ identificado em bairros como Vila Maria e Tatuapé, teria se mantido. O fenômeno novo seria o crescimento do voto em Maluf em bairros mais abastados e de alta escolaridade, como Jardim Paulista e Pinheiros, antes refratários ao candidato. Para os autores, Maluf teria conseguido colocar-se como contraponto consistente ao PT, o que atraiu os setores de maior renda em uma nova configuração eleitoral mais classista / ideológica e menos de oposição frente ao regime autoritário.

\section{Consolidação Democrática: Enfim a Estabilidade?}

Nos anos 1990, a entrada de um novo partido em cena (o PSDB, oriundo de dissidência do PMDB) traz importantes implicações ao panorama eleitoral paulista. Em 1994, a vitória de Mario Covas inicia o longo predomínio eleitoral objeto desta dissertação. Se nos anos 1990 a disputa essencial foi com Paulo Maluf, ao longo da década de 2000 consolidou-se a polarização entre o PT e PSDB também em âmbito estadual - ainda que, nos três últimos pleitos (2006, 2010 e 2014), os candidatos do PSDB tenham vencido em primeiro turno - sendo que, na última eleição do período, o segundo colocado foi um candidato peemedebista, Paulo Skaf.

Simoni Jr. (2012) analisou os resultados eleitorais para o Estado de São Paulo nas eleições para cargos do Executivo (federal, estadual e municipal) nos anos entre 1982 e 2008, com foco no período pós-94. O autor procurou demonstrar que as bases eleitorais dos partidos apresentaram grau elevado de estabilidade: os níveis altos de volatilidade encontrados em certos pleitos do período ocorreriam não tanto por instabilidades do eleitorado ou debilidades do sistema partidário, mas sim pelas estratégias dos partidos de lançarem ou não candidatos.

as dificuldades do partido à época: "êta povo pra gostar de patrão!". (Folha de São Paulo, 10 de Setembro de 1986).

${ }^{10}$ A presença de um voto urbano popular de direita é, nas palavras de Limongi e Mesquita (2008), "de difícil digestão", tendo em vista as teorias clássicas de sociologia política que identificam urbanização e industrialização com aumento progressivo no voto em partidos de caráter reformista e/ou à esquerda. Sobre esta visão clássica da sociologia política aplicada ao caso brasileiro, ver SOARES (1973). André Singer (1999), a partir de pesquisas de survey, aponta que a clivagem ideológica no caso brasileiro se dá sobretudo em termos de ruptura ou manutenção da ordem. Setores populares menos organizados (não vinculados a sindicatos, por exemplo) temeriam a eclosão de conflitos sociais e tenderiam ao voto conservador (e mantenedor da ordem). 
Com relação às eleições para governador, o autor identificou uma elevada coerência entre os pleitos no período. A partir de observações estatísticas, verificou que a proeminência do PT e do PSDB nas eleições recentes deve-se em parte à estratégia desses partidos de lançarem candidatos em todas as eleições.

Sobre o crescimento do PT em São Paulo, Davidian (2013) interpretou-o como fenômeno sobremaneira organizacional. Neste sentido, o crescimento do PT entre os estratos mais populares seria menos oriundo de possível realinhamento eleitoral ocorrido entre os pleitos de 2002 e 2006, mas sobretudo fruto do paulatino espraiamento da agremiação no território (com o lançamento de diversas candidaturas e a organização de diretórios locais nos municípios ${ }^{11}$ ). Ao analisar resultados eleitorais do partido nas últimas duas décadas, a autora sugere que já em 2002 o partido aumentara consideravelmente sua votação pelo interior do Estado.

Por fim, Meneghello e Bizarro (2012) traçam uma ampla análise do panorama eleitoral paulista após a redemocratização, focado sobretudo em bases regionais. Concluem os autores que a distribuição das preferências eleitorais no Estado possui forte característica regional, derivada sobretudo das diferenças socioeconômicas entre as regiões. De um lado, municípios menores e eminentemente agrícolas tenderiam a apoiar partidos de cunho conservador, ao passo que partidos de esquerda (PT à frente) teriam maior apoio em regiões urbanas e industrializadas (ainda que, a partir de 2006, a votação do PT tenha iniciado processo de "espalhamento" - nas palavras dos autores pelo Estado). Tais constatações demonstrariam, assim, a presença de uma dinâmica centro-periferia no perfil eleitoral do Estado.

\section{Um Breve Balanço}

Neste capítulo buscamos apresentar um panorama sucinto da literatura sobre o comportamento eleitoral no Estado de São Paulo (sobretudo nas eleições para governador) em diferentes períodos. Vale encerrá-lo com uma breve análise sobre tais interpretações, buscando encontrar elementos comuns ou padrões analíticos nas diferentes abordagens e estabelecer o campo em que esta investigação se situa em termos da literatura abordada.

\footnotetext{
11 Ainda sobre o aspecto da organização local, Bizarro Neto e Freitas (2011) elaboraram estudos estatísticos para verificar a relação entre a presença de diretórios municipais efetivamente instalados (ou seja, não em formato de "comissões provisórias") e números de filiados. De acordo com os testes efetuados pelos autores, o efeito organizacional é menor em eleições majoritárias, mas ainda assim não é desprezível. Em eleições proporcionais, há forte correlação entre votação do partido e organização local.
} 
Primeiramente, vale ressaltar a característica "intrigante" que cerca os resultados eleitorais do Estado de São Paulo e que propiciaram um rico campo de estudos eleitorais. No Regime de 1946, as elevadas votações de lideranças consideradas "populistas" e a fraqueza dos grandes partidos nacionais do período (a trinca PSD, UDN e, sobretudo, o PTB, dado peso industrial do Estado); no Regime Militar, a votação esmagadora do MDB no pleito de 1974; nos anos 1980, já na transição democrática, a emergência (ou persistência) do voto em partidos e lideranças conservadoras (como Paulo Maluf), mesmo em setores populares urbanos. Neste contexto, a investigação acerca da prevalência eleitoral de um mesmo partido por seis eleições consecutivas ganha relevância ainda maior.

Importante notar também as diferentes abordagens de comportamento eleitoral ${ }^{12}$ subjacentes aos estudos eleitorais que apresentamos. Se nos anos 1950 e 1960 prevaleciam estudos ancorados na sociologia política (ou seja, a conexão entre as características de classe do eleitorado e suas escolhas político-partidárias), nos anos 1970 Lamounier (op. cit.) introduz a abordagem psicológica nos estudos eleitorais. Enfatiza-se, assim, menos classes e bases sociais e mais a absorção das informações político-partidárias pelo eleitorado. Por essa razão, questões como escolaridade, inserção política e identidade partidária tornam-se mais relevantes, sob esta abordagem, para a compreensão dos sufrágios.

No período recente, diversos estudos têm por foco aspectos organizacionais e de competição do sistema político, influenciados por matriz de escolha racional do comportamento eleitoral. Enfatizam-se, assim, os aspectos institucionais do "mercado" político, em que a interação competitiva entre os agentes é o elemento fundamental para formação das expectativas dos eleitores.

Deste modo, é possível perceber que o caso paulista não passou imune pela mudança de prisma da própria ciência política brasileira. A ênfase da sociologia política de meados do século XX paulatinamente cede espaço para análises influenciadas pela teoria da escolha racional, em que questões institucionais do sistema político-partidário tornam-se protagonistas na literatura.

Resta claro que esta divisão (a saber, abordagem sociológica - abordagem psicológica - abordagem econômica) encerra certo grau de arbitrariedade, além de uma

\footnotetext{
${ }^{12}$ Sobre as diferentes abordagens ou escolas, ver FIGUEIREDO (1991).
} 
distinção cronológica um tanto imprecisa. Nos anos 1980, por exemplo, análises como a de Antonio Flavio Pierucci e Marcelo Lima (op. cit.) centram-se na abordagem sociológica do fenômeno eleitoral, com novos elementos para além da interação de classes sociais (entram em cena também questões como religiosidade e valores morais do eleitorado). Já no período recente, conforme relatado, autores como Rachel Meneghello e Fernando Bizarro (op. cit.) ressaltam a importância do aspecto regional (portanto, de bases sociais) para a dinâmica eleitoral.

Verifica-se, assim, que por meio de diferentes abordagens metodológicas e teóricas, o Estado de São Paulo configura-se como objeto privilegiado de pesquisa seja por sua importância política e econômica (conforme mencionado no início deste capítulo), seja pela sua relevância teórica no campo de estudos de comportamento eleitoral ao longo do tempo ${ }^{13}$.

Sob nosso ponto de vista, se é certo que a dinâmica interativa institucional entre os partidos ganhou predominância nos estudos político-eleitorais ${ }^{14}$, permanece como questão essencial a busca por elementos de diferenciação ideológica e de base social entre as diferentes agremiações - que, a despeito de não mais responderem a categorias de classe "rígidas" construídas ao longo do século XX, persistem, ainda que de maneira reconfigurada, como elementos significativos de representação e clivagem das diferenças sociais (LIPSET; 2001).

Assim, este trabalho insere-se nesta perspectiva, uma vez que procuraremos encontrar indícios de clivagens partidárias e bases de sustentação eleitoral a partir das diferenças sociodemográficas presentes no Estado de São Paulo em termos de condições socioeconômicas do eleitorado, tamanho dos municípios e distribuição regional dos territórios eleitorais.

Por fim, destacamos que o intuito deste trabalho é também contribuir para a compreensão de um dos principais partidos brasileiros, o PSDB. A análise das bases sociais de votação do partido (tanto do ponto de vista regional quanto das eventuais

\footnotetext{
${ }^{13}$ Seanwright \& Gerring (2008) apresentam uma tipologia de estudos de caso e as diferentes implicações metodológicas do processo de seleção. Baseado na tipologia dos autores (Idem; pp. 297-298) poder-se-ia dizer que o caso paulista configura-se tanto como um caso típico (dada sua relevância do ponto de vista da literatura) quanto um caso influente (pela importância significativa deste colégio eleitoral para o funcionamento do sistema político partidário brasileiro).

${ }^{14}$ Amaral (2013) elabora síntese das tendências recentes em estudos partidários na literatura, bem como aponta algumas lacunas a serem preenchidas na análise de partidos no Brasil (tais como número e perfil de filiados, processos de recrutamento de lideranças, fontes de financiamento, entre outros).
} 
clivagens encontradas) em seu principal reduto eleitoral poderá trazer novos elementos para categorização de um partido cuja bibliografia, nas palavras de Juarez Guimarães (2009), é ainda incipiente. 


\section{Capítulo 2 - Especificidades do Realinhamento Eleitoral em São Paulo}

\section{Premissas}

$\mathrm{Na}$ seção anterior, fizemos um breve balanço da literatura referente ao comportamento eleitoral no Estado de São Paulo. Nos diferentes regimes políticos - a democracia pluripartidária de 1946-1964, o bipartidarismo imposto pelo Regime Militar e a redemocratização pós-1982 -, foram encontradas diferenças relevantes no perfil social dos eleitores de cada partido. Neste sentido, a despeito da aparência caótica e do pouco enraizamento dos partidos brasileiros, são perceptíveis as clivagens existentes entre as diferentes agremiações e candidaturas.

Em nível nacional, há tempos é identificada a prevalência de padrões sociais definidores do voto nas eleições nacionais. Com efeito, a alternância eleitoral ocorrida em 2002 e a chegada do PT ao poder central (e sua recondução nos pleitos seguintes) foi objeto de estudos referentes aos redutos e principais bases sociais de apoio ao partido. No terreno belicoso da ciência política, parece haver um consenso que une as diferentes escolas teóricas e metodológicas: a partir de 2006, o PT possui seus principais nichos de apoio entre os eleitores de classes mais baixas e nas regiões de menor desenvolvimento socioeconômico, sendo inverso o perfil de votação de seu principal oponente, o PSDB.

Fernando Limongi e Fernando Guarnieri (2014), em análise das eleições presidenciais de 1989 a 2010 a partir dos padrões médios de escolaridade do eleitorado nas seções eleitorais, indicam que o perfil de votos no PT e no PSDB nas eleições de 1994 e 1998 (as primeiras em que estes partidos polarizaram a disputa nacional) possuía a seguinte característica:

“(...) Fernando Henrique [PSDB] teve mais votos quanto menor a escolaridade dos eleitores. Para o PT, a relação se inverte, isto é, seu desempenho melhorou à medida que escolaridade nas seções se elevou." (LIMONGI \& GUARNIERI, op.cit., p. 13).

Nas eleições de 2002, o PT teria conseguido atrair novos eleitores e, a partir de um crescimento homogêneo nos diferentes estratos eleitorais, conquistou a presidência, 
O PSDB, por outro lado, teve desempenho inverso: perda acentuada em todos os estratos, com queda mais expressiva na região Nordeste ${ }^{15}$.

Nas eleições de 2006, o perfil que se mantinha relativamente estável ao longo dos três pleitos anteriores teve uma importante modificação: o voto no PT e no PSDB passa a ter bases sociais distintas. O percentual de votos obtidos pelos partidos passa a formar um crescente invertido: quanto menor o grau de escolaridade médio das seções eleitorais ${ }^{16}$, maior o percentual de votação no PT; quanto maior o grau de escolaridade, maior apoio ao PSDB.

Andre Singer (2012) encontrou resultados análogos ao analisar os pleitos presidenciais do período recente. Ao chamar a atenção para o fato de que os percentuais de votos em Lula (PT) nas duas eleições (2006 e 2002) eram semelhantes, o autor aponta diferenças nas bases sociais de apoio nos dois pleitos. Se até 2002 o PT obtinha maiores votações entre os eleitores de maior escolaridade e renda, em 2006 ocorre o inverso: pesquisas de opinião estratificadas por renda demonstravam o apoio de setores mais abastados a Alckmin (PSDB) e das classes mais populares a Lula ${ }^{17}$ :

“A divergência entre os estratos de renda crescerá ao longo de 2006, e os números encontrados pelo IBOPE perto do primeiro e do segundo turno expressam uma disputa socialmente polarizada (...). (...) A disposição da parcela mais pobre de sufragar Lula inverte-se de maneira linear à medida que aumenta o rendimento, de sorte que os mais ricos dão folgada maioria à Alckmin."

“(...) Lula foi eleito, sobretudo, pelo apoio que teve nesse segmento [população de baixíssima renda], enquanto Alckmin contou, além dos votos mais ricos, com certa sustentação na fatia de eleitores de classe média baixa, que vagamente corresponde ao que o mercado chama de 'Classe C'”. (SINGER, 2012, p. 54).

\footnotetext{
${ }^{15}$ Os autores atribuem este fator ao fim da aliança com o PFL/DEM, partido que à época tinha importante penetração na região.

${ }^{16}$ Os autores utilizam o índice médio de escolaridade das seções eleitorais (dado disponibilizado pelo Tribunal Superior Eleitoral) como forma de aferição do nível de desenvolvimento socioeconômico das localidades.

${ }^{17}$ Utilizamos apenas estes dois trabalhos para fins de explanação do argumento, sem nos determos na vasta bibliografia referente aos pleitos presidenciais brasileiros. Ver, a esse respeito, CARREIRÃO \& KINZO (2002), CARREIRÃO (2002), BALBACHEVISKY \& HOLZACKER (2008), HUNTER E POWER (2007), ZUCCO JR. (2008) e SOARES \& TERRON (2010).
} 
Como explicar, porém, estas diferenças significativas entre os dois pleitos? O consenso em relação aos resultados dissipa-se quando da interpretação dos mesmos.

Limongi e Guarnieri (op.cit.) enfatizam a perda do voto dos mais escolarizados pelo PT como fator preponderante, eleitorado este sobre o qual o partido havia avançado em 2002. Além disso, apontam que a estrutura diferente de competição, com a ausência de candidaturas de "terceira via" viáveis, tornou menor o rol de opções disponível ao eleitorado $^{18}$. Em suas palavras:

“(...) Assim, levando em conta a estrutura da competição, a votação de Lula em 2006 não apresentou uma inversão de tendências. Pelo contrário, representou a continuidade da penetração do PT entre os eleitores de mais baixa renda; penetração esta que, como mostra o segundo turno de 2002, pôde se dar sem o controle da máquina do Estado. A inversão se deu entre os mais escolarizados (mais ricos), sobre os quais o partido havia avançado em 2002” (LIMONGI \& GUARNIERI, op.cit. p. 18).

Os autores pontuam ainda que o caráter do voto nos setores menos escolarizados da população não se deve a elementos clientelistas - seja como moeda de troca de políticas compensatórias (sobretudo o Programa Bolsa Família), seja pelo "fator governo" (a influência da máquina governamental nos assim chamados "grotões"):

"As políticas sociais perseguidas pelo PT, qualquer que seja a forma como venham a ser classificadas, não podem ser vistas como precondições necessárias para atrair e conquistar o voto dos mais pobres. O PT sempre teve votos entre esses eleitores e passou a ter o apoio da maioria deles antes mesmo de assumir o poder. Isso não significa dizer que as políticas sociais adotadas pelo governo petista não tenham peso eleitoral. Obviamente, tiveram e continuam tendo. Por meio dessas políticas, o PT ampliou sua vantagem nesse estrato de eleitores. Tão ou mais importante que esse avanço foi o fato de ter retido o apoio conquistado fora do governo. Promessas foram cumpridas, e os eleitores recompensaram o partido" (LIMONGI \& GUARNIERI, op.cit.).

\footnotetext{
${ }^{18}$ Em 2002, Anthony Garotinho (à época no PSB) e Ciro Gomes (à época no PPS) disputaram com Lula e Serra e obtiveram, respectivamente, $17,8 \%$ e 11,9\% dos votos válidos. Em 2006, a terceira colocada, Heloisa Helena (PSOL) obteve $6,8 \%$ dos votos válidos. Fonte: TSE.
} 
Vê-se, assim, que a ênfase dos autores recai em elementos estratégicos da competição (em consonância com a perspectiva neoinstitucionalista) e na preponderância do voto econômico como matriz explicativa para o comportamento eleitoral (a saber, a "premiação", pelos eleitores, de candidatos que executaram boas políticas). Em ambas (elementos da competição e voto econômico), a "escolha racional" dos agentes (elites políticas e eleitores) seriam as variáveis preponderantes para a explicação do fenômeno de "inversão de bases"19 ocorrido em 2006.

Singer (2012), por sua vez, parte de referencial teórico diverso. O autor procura conjugar os resultados eleitorais com aspectos sociais (em termos de classe) e ideológicos deste novo eleitorado. Segundo o autor, diferentes pesquisas de opinião sobre auto-identificação no espectro ideológico (esquerda, centro e direita) realizadas desde 1989 mostravam tendência de eleitores de estratos inferiores de renda posicionarem-se à direita na escala. Tal posicionamento, porém, tinha suas particularidades:

“(...) Não obstante, tratava-se de direita peculiar, uma vez que favorável à intervenção do Estado na economia. (...) Como resolver a aparente contradição? Sugeri que os eleitores mais pobres buscariam a redução da desigualdade, da qual teriam consciência, por meio da intervenção direta do Estado, evitando movimentos sociais que pudessem desestabilizar a ordem [grifo no original]". (SINGER, 2012, p. 58)

Este "conservadorismo popular" (expressão do autor) seria fruto das características intrínsecas do contingente mais numeroso da população brasileira, formado sobremaneira pelo que Paul Singer (apud SINGER, 2012, p. 76) denominou "subproletariado". Esta fração de classe seria formada por trabalhadores de renda muito baixa (empregados domésticos, assalariados de produtores diretos, entre outros) “destituídos das condições mínimas de participação na luta de classes” (idem, p. 77). Por não se encontrarem amparados por mecanismos de proteção social e autodefesa (como carteira de trabalho assinada e sindicatos), temem a radicalização da luta de classes em momentos de instabilidade (idem, p. 75). Por isso, rechaçam partidos e

\footnotetext{
${ }^{19}$ Importante ressaltar, uma vez mais, que, na visão dos autores, tal inversão deu-se entre os eleitores de alta renda (op. cit., p. 18). Sobre as escolas teóricas de comportamento eleitoral, ver FIGUEIREDO (1991).
} 
discursos que proponham quebra da ordem, rupturas, greves e "bagunças" de qualquer natureza.

Seria essa a razão pela qual Lula e o PT não teriam conseguido penetrar neste contingente populacional (grande maioria do eleitorado e concentrado no Nordeste brasileiro) nas eleições anteriores. A base do partido permanecia entre os setores do proletariado organizado e setores médios alinhados à esquerda - situação que persiste até 2002.

Após a vitória ${ }^{20}$ naquele ano, ao manter elementos da política econômica do governo anterior e o compromisso com a ordem (tais como o tripé macroeconômico, sobretudo a ênfase no combate à inflação), o governo Lula rompeu, por um lado, com a resistência histórica do "conservadorismo popular". Por outro, a adoção de medidas de caráter redistributivo e de aumento da renda (tais como o Programa Bolsa Família e a expansão do crédito e do salário mínimo) propiciou a adesão plena destes mesmos segmentos do eleitorado. No entanto, o escândalo do mensalão teria alijado parte significativa do tradicional eleitorado "médio" do partido. Este duplo movimento viria a ser o motor do realinhamento eleitoral ocorrido entre as eleições de 2002 e 2006.

Com diferentes abordagens teóricas e metodológicas, os trabalhos citados apontam de maneira inequívoca a presença de bases sociais distintas no voto presidencial dos principais partidos brasileiros. Ainda que não concordem com o conceito de realinhamento eleitoral - nos termos apresentados por Singer (op. cit.) e, em certa medida, corroborado outros autores (SOARES \& TERRON; 2010; HUNTER \& POWER; 2007; ZUCCO, 2008), Limongi e Guarnieri (op. cit.) afirmam textualmente que a inversão de bases (ao menos em relação ao PT e entre os eleitores nos locais de maior nível de desenvolvimento) ocorre na passagem dos pleitos nacionais de 2002 a 2006. Desse modo, é possível argumentar, em consonância com a corrente majoritária da literatura, que as mudanças no perfil eleitoral de PT e PSDB em nível nacional a partir de 2006 podem ser interpretadas enquanto fenômeno de realinhamento eleitoral.

Este breve percurso preliminar pelo cenário político nacional teve por objetivo situar os termos da discussão deste capítulo. Até que ponto as profundas modificações

\footnotetext{
${ }^{20} \mathrm{O}$ autor aponta que este programa já se delineava quando do lançamento da "Carta ao Povo Brasileiro" em julho de 2002, documento pelo qual o partido comprometia-se, em caso de vitória, com "sólidos fundamentos macroeconômicos" (idem, p. 97). Frisa, porém, que a adesão maciça do subproletariado teria ocorrido depois da passagem pelo governo (idem, p. 62).
} 
ocorridas das bases sociais de voto dos principais partidos brasileiros - ocorrida nas eleições nacionais a partir de 2006 - teve implicações ou reflexos nos contextos eleitorais subnacionais? De maneira mais clara: tal movimentação teria ocorrido também em eleições estaduais?

Previamente, poderia se colocar a seguinte objeção: haveria, de fato, correspondência entre as eleições em nível nacional e local (no caso, estadual)? Afinal, tratam-se de pleitos distintos, com padrões de interação partidária própria e magnitudes (populacionais, geográficas, entre outras) diversas.

A literatura, porém, aponta a prevalência das disputas nacionais nas disputas nos Estados (LIMONGI \& CORTEZ; 2010). Para além da coincidência cronológica de ambos os pleitos (fator em si não desprezível em termos de indução de preferência dos eleitores), a montagem de alianças e coligações estaduais reflete, em grande medida, a polarização encontrada em nível nacional ${ }^{21}$. Nesse sentido, é de se esperar que eventuais mudanças ocorridas no panorama nacional reflitam nas dinâmicas eleitorais dos Estados.

Estas foram, com efeito, as evidências encontradas por André Borges (2010) ao analisar a alternância eleitoral em Estados cujo predomínio político assentara-se há certo tempo sobre determinado partido ou grupo político. A partir de um estudo de caso sobre o Estado da Bahia, o autor argumenta que a troca de guarda em nível federal teve papel essencial na derrota do "carlismo" (DEM/PFL) no pleito de 2006, quando o candidato petista Jaques Wagner logrou interromper um ciclo político de dezesseis anos do grupo de Antonio Carlos Magalhães (ACM) à frente do governo baiano. Para o autor, o recente arranjo federativo brasileiro (que possibilita a interação entre União e municípios sem intermediação estadual) e o aumento de políticas sociais diretamente executadas pelo governo central podem ter colocado obstáculos importantes para as máquinas políticas estaduais hegemônicas ${ }^{22}$. Ter-se-ia, assim, um ambiente de competição eleitoral mais aberto e menos "confortável” para as antigas elites políticas locais.

\footnotetext{
${ }^{21}$ Limongi e Cortez (op. cit.) apontam que, no pleito de 2010, em todas as eleições para governador de Estado preponderaram duas candidaturas: uma alinhada à situação e outra à oposição em nível nacional.

${ }^{22} \mathrm{O}$ autor dialoga, do ponto de vista teórico, com autores do início dos anos 1990 que apontavam a força política das máquinas estaduais no processo de redemocratização - nas palavras de Fernando Abrucio, os governadores se configurariam como "barões da federação" (ABRUCIO; 1998).
} 
Diante deste cenário, que impactos o realinhamento eleitoral ocorrido em nível nacional teria em um Estado cujo predomínio político de uma legenda oposicionista se dava em termos semelhantes ao ocorrido, por exemplo, no Estado da Bahia?

\section{Hipóteses}

Dado que a distribuição de preferências eleitorais entre os partidos brasileiros possui um padrão de distribuição socioeconômico singular (conforme apontado na seção anterior), é importante ressaltar as relevantes desigualdades intrarregionais existentes no Brasil. As disparidades não se concentram de maneira equânime ao longo do território nacional.

Para fins de exposição do argumento, utilizamos indicadores de renda e escolaridade para três Estados brasileiros (São Paulo, Minas Gerais e Maranhão), além da média geral nacional. Para fins de comparação com São Paulo (objeto deste trabalho), escolhemos um Estado "díspar” em termos de nível de desenvolvimento (Maranhão) e um Estado limítrofe ao paulista - porém reconhecido por suas disparidades internas (Minas Gerais) ${ }^{23}$. O intuito é comparar as diferentes unidades federativas a partir da distribuição interna de suas populações em termos de nível de escolaridade e renda. Os dados seguem apresentados nos gráficos a seguir:

\footnotetext{
${ }^{23}$ Dados do Censo Demográfico de 2010 demonstram essa disparidade. Enquanto 24,2\% da população do Baixo e Médio Jequitinhonha (norte do Estado) era composta por analfabetos, na região Sul do Estado este contingente era de 7,3\% da população. De acordo com dados do PNUD (Atlas do Desenvolvimento Humano do Brasil - 2010), esta mesma região possuía a totalidade de seus municípios com Índice de Desenvolvimento Humano médio ou alto, enquanto no Baixo e Médio Jequitinhonha nenhum município foi considerado de alto desenvolvimento humano (72\% dos municípios possuíam nível baixo). Fonte: Portal "Território de Desenvolvimento" (www.mapaderesultados.mg.gov.br; acesso em 05 de setembro de 2015).
} 


\section{Gráfico 1 - Distribuição de Arranjos Familiares por Classe de Rendimento Mensal}

$-2013$

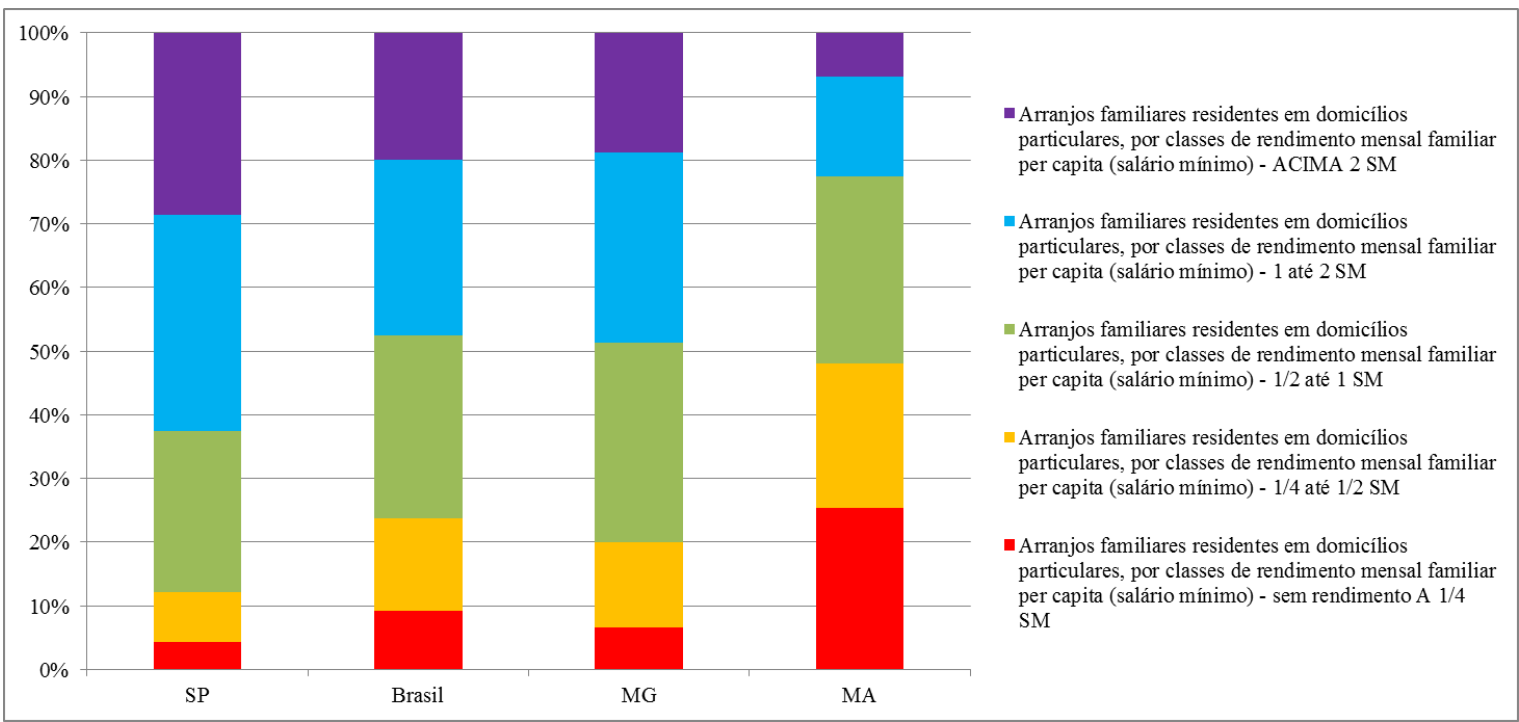

Fonte: Síntese de Indicadores Sociais 2014 - Uma Análise das Condições de Vida da População Brasileira (disponível em: http://www.ibge.gov.br/estadosat)

\section{Gráfico 2 - Distribuição de Pessoas (25 anos ou mais) por Grupos de Anos de Estudo (2013)}

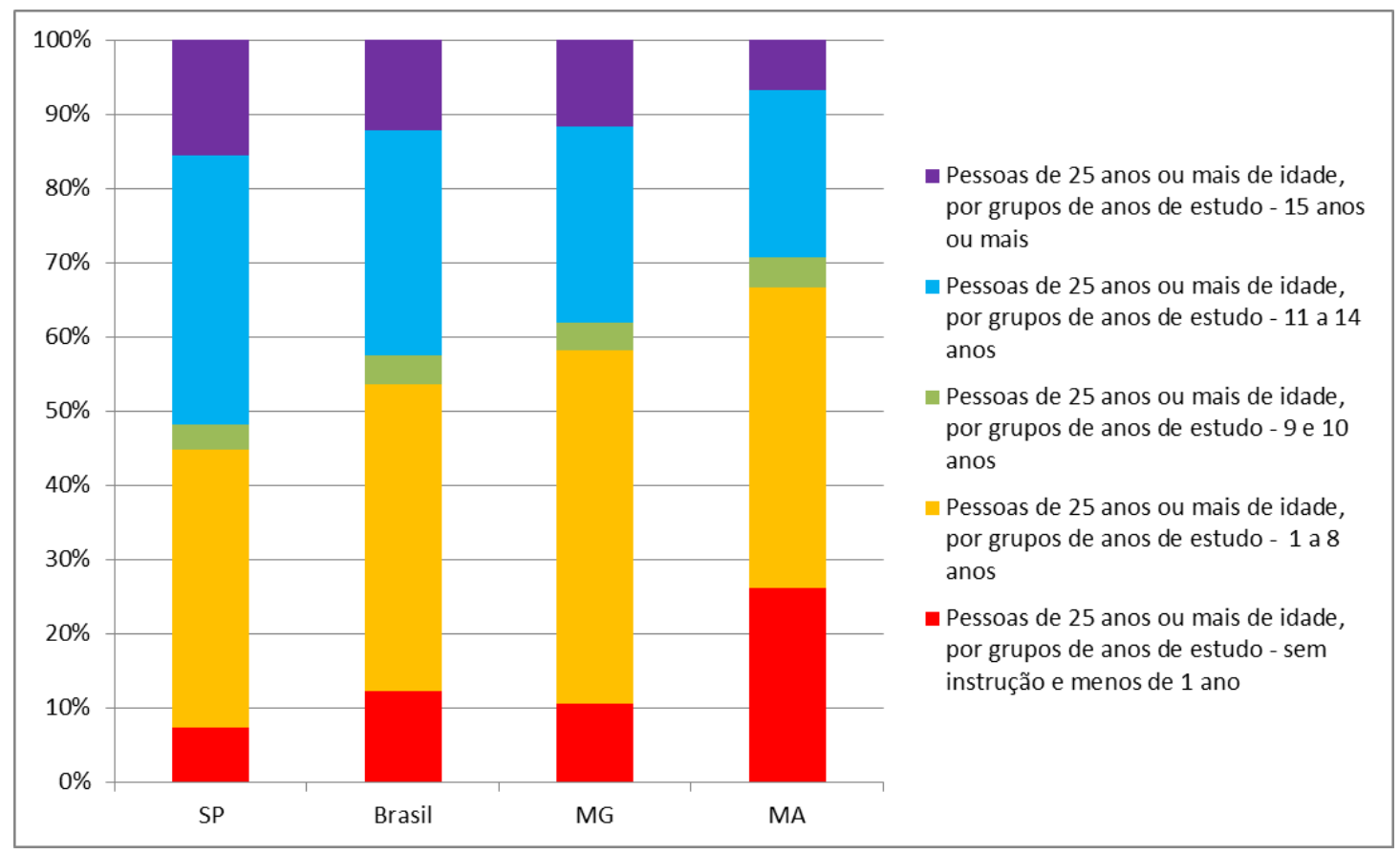

Fonte: Síntese de Indicadores Sociais 2014 - Uma Análise das Condições de Vida da População Brasileira (disponível em http://www.ibge.gov.br/estadosat) 
Ainda que pareça redundante a constatação, saltam à vista as diferenças presentes entre os Estados e entre esses e a média geral nacional. Enquanto o Maranhão possuía quase metade de suas famílias com rendimentos de até meio salário mínimo per capita, em São Paulo quase $60 \%$ dos arranjos familiares obtêm mais de um salário mínimo per capita de rendimento mensal. Em termos de escolaridade, em São Paulo mais da metade da população adulta possui 11 anos ou mais de estudo (ou seja, concluiu o ensino médio), enquanto que no Maranhão este número não chega a um terço dos cidadãos do Estado.

Interessante notar as semelhanças entre a distribuição de escolaridade e renda brasileira e mineira. De maneira um tanto imprecisa, poderia se dizer que o Estado mineiro é uma pequena amostra do Brasil. Em termos eleitorais, ainda que também de maneira um tanto imprecisa, Minas Gerais apresentou, em 2014, resultados eleitorais semelhantes aos do conjunto brasileiro.

Quadro 1 - Votos Válidos nas Eleições Presidenciais de 2014 (1º Turno) Comparação MG x Brasil

\begin{tabular}{lll}
\hline Candidato (Partido) & Votos Válidos - Brasil & Votos Válidos - MG
\end{tabular}

\begin{tabular}{lcc}
\hline Dilma (PT) & $41,6 \%$ & $43,5 \%$ \\
\hline Aécio (PSDB) & $33,5 \%$ & $39,7 \%$ \\
Marina (PSB) & $21,3 \%$ & $14 \%$ \\
\hline
\end{tabular}

Fonte: TSE

Sabemos que tal comparação demandaria estudos mais aprofundados e não leva em conta outras características relevantes na decisão do voto ${ }^{24}$. Não obstante, é relevante destacar uma vez mais a importância dos padrões de distribuição socioeconômica do conjunto da população para a identificação de bases eleitorais dos partidos. Tal fato torna-se ainda mais claro quando comparados os resultados do mesmo pleito para os outros Estados previamente escolhidos, São Paulo e Maranhão.

\footnotetext{
${ }^{24}$ Aécio Neves, por exemplo, foi governador de Minas Gerais, fato este que certamente influencia na sua capacidade de angariar preferências neste território (tanto assim que quase empatou com a candidata do PT no primeiro turno no seu Estado de origem). Ademais, as coligações em nível local (no linguajar comum, os almejados "palanques" regionais) também podem vir a ter influência na estrutura disponível aos candidatos presidenciais nos diferentes Estados. Sobre este aspecto, ver LIMONGI \& CORTEZ (op. cit.).
} 


\section{Quadro 2 - Votos Válidos nas Eleições Presidenciais de 2014 (1 Turno)- Comparação MA x SP x Brasil}

\begin{tabular}{cccc}
\hline Candidato (Partido) & Vot Válidos Brasil & Vot Válidos - SP & Vot Válidos - MA \\
\hline Dilma (PT) & $41,6 \%$ & $25,8 \%$ & $69,5 \%$ \\
Aécio (PSDB) & $33,5 \%$ & $44,2 \%$ & $11,6 \%$ \\
Marina (PSB) & $21,3 \%$ & $25,1 \%$ & $17 \%$ \\
\hline
\end{tabular}

Fonte: TSE

Enquanto em São Paulo o candidato do PSDB teve vinte pontos percentuais de vantagem sobre a segunda colocada, no Maranhão sua performance por pouco não ficou em apenas um dígito - inclusive com a perda do segundo posto para a adversária Marina Silva (PSB). Dilma (PT), por sua vez, teve elevada votação no Estado do Nordeste (mais de dois terços do total de votos válidos), mas obteve apenas um quarto das preferências em São Paulo (sendo quase alcançada por Marina).

A diferença dos resultados nas diferentes unidades de análise é significativa por si só, mas torna-se menos surpreendente quando conjugamos os índices de votação obtidos pelos partidos com as características sociodemográficas de cada localidade apresentadas anteriormente. Se, como observamos na seção anterior, os índices de votação de PT e PSDB em eleições presidenciais estão relacionados com o nível de desenvolvimento socioeconômico do eleitorado - inversa e diretamente, pela ordem -, é esperado que tal relação seja ainda mais perceptível quando analisamos Estados de características tão díspares.

Em relação ao nosso objeto primordial de análise, o Estado de São Paulo, gostaríamos de salientar este ponto: dado que este possui um número maior de eleitores de poder aquisitivo e escolaridade mais elevados (tanto em termos absolutos quanto na distribuição destes segmentos no conjunto de sua população), é esperado um apoio eleitoral substantivo ao PSDB no Estado paulista em eleições presidenciais.

Seria este mesmo padrão encontrado em outros contextos eleitorais? A hegemonia eleitoral do partido tucano em São Paulo nas eleições para governador desde 1994 parece indicar fortes indícios neste sentido. Assim, esta é a hipótese norteadora deste capítulo: tendo em vista que o Estado de São Paulo possui parcela majoritária do 
eleitorado com padrões mais elevados de escolaridade e renda, este eleitorado constitui a base mais significativa de apoio ao PSDB (em consonância com o padrão de votação nacional). Tal base de sustentação se constituiria como fator relevante para compreensão das seguidas vitórias tucanas nas eleições paulistas para governador.

Para efetuarmos a comprovação desta hipótese, analisaremos dados de pesquisas eleitorais $^{25}$ (estratificados por renda e escolaridade) nas eleições estaduais para governador desde os anos 1990 - porém, com ênfase maior no período pós-2002, quando a literatura aponta a reconfiguração eleitoral ocorrida em âmbito nacional. Utilizaremos também dados de resultados eleitorais do período, conjugados com os padrões de escolaridade médio dos eleitores.

\section{Antecedentes - As Eleições de 1990, 1994 e 1998}

Fundado em 1988, o PSDB participa de sua primeira eleição para governador do Estado de São Paulo em 1990 com a mesma candidatura que, no ano anterior, obtivera apenas o quarto lugar na eleição presidencial. Ainda que não tenha obtido êxito na disputa nacional, Mario Covas obteve quase metade de seus votos totais no Estado de São Paulo em 1989. Teria ficado em terceiro lugar na disputa, se considerado apenas o resultado paulista, muito próximo dos dois primeiros colocados - Paulo Maluf (PDS/PP) e Fernando Collor de Mello (PRN/PTC) ${ }^{26}$.

Quando das eleições estaduais em 1990, porém, Covas obteve desempenho eleitoral muito inferior - foram 1,7 milhões de votos a menos e um distante terceiro lugar, atrás do candidato da situação, o peemedebista Luiz Antonio Fleury Filho, e o eterno rival Paulo Maluf (PDS/PP) ${ }^{27}$. Se a derrota para Maluf não pode ser considerada surpreendente (lembre-se que o candidato do PDS/PP já o havia derrotado no pleito

\footnotetext{
${ }^{25}$ Utilizamos dados das pesquisas do Instituto Datafolha realizadas às vésperas do primeiro ou do segundo turno - mais próximas, assim, ao momento de decisão do voto. Não dispusemos de algumas informações relevantes em algumas das pesquisas mais antigas, tais como margem de erro e intervalo de confiança. Agradecemos ao Datafolha pela disponibilização de parte das pesquisas. Os dados de alguns dos levantamentos (sobretudo os mais antigos) foram disponibilizados pelo CESOP/Unicamp, a quem também agradecemos.

${ }^{26}$ Covas obteve 7,79 milhões de votos em todo Brasil - desses, 3,8 milhões apenas São Paulo. Na disputa "particular" paulista, Collor obteve $23,4 \%$ dos votos totais, Maluf $22,5 \%$ e Covas $21,8 \%$ (Fonte: Fundação SEADE e Portal "Paulística Eleitoral" / TRE-SP). Limongi e Guarnieri (op.cit., p. 10) apontam que a grande dificuldade de Maluf e Covas naquele pleito foi justamente obter penetração em outros Estados para além do paulista. Ainda segundo os autores, o PSDB viria a contornar essa situação no pleito nacional seguinte por meio da aliança com o PFL/DEM, partido que à época possuía importantes bases eleitorais no Nordeste brasileiro.

${ }^{27}$ Os resultados gerais de todas as eleições para o governo do Estado de São Paulo estão disponíveis no Anexo I.
} 
nacional anterior conjuntamente com um candidato do mesmo "espectro" político ${ }^{28}$ ), a passagem do até então desconhecido Fleury para a segunda rodada eleitoral merece maior investigação. Os índices de preferência estratificados por renda e escolaridade do eleitorado permitem algumas inferências.

Quadro 3- Preferência dos Eleitores por Renda Familiar Mensal - Eleições para Governador (1990)

\begin{tabular}{lcccc}
\hline \multicolumn{1}{c}{$\begin{array}{c}\text { Candidato } \\
\text { (Partido) }\end{array}$} & $\begin{array}{c}\text { Até 2 Salários } \\
\text { Mínimos }\end{array}$ & $\begin{array}{c}\text { 2 a 5 Salários } \\
\text { Mínimos }\end{array}$ & $\begin{array}{c}\text { 5 a 10 Salários } \\
\text { Mínimos }\end{array}$ & $\begin{array}{c}>\text { 10 Salários } \\
\text { Mínimos }\end{array}$ \\
\hline $\begin{array}{l}\text { Maluf } \\
\text { (PDS/PP) }\end{array}$ & $36 \%$ & $34 \%$ & $39 \%$ & $39 \%$ \\
Fleury (PMDB) & $36 \%$ & $37 \%$ & $29 \%$ & $22 \%$ \\
Covas (PSDB) & $7 \%$ & $9 \%$ & $9 \%$ & $17 \%$ \\
\hline Plínio (PT) & $6 \%$ & $6 \%$ & $12 \%$ & $12 \%$ \\
\hline
\end{tabular}

Fonte: Datafolha. Pesquisa com amostra estadual (SP) de 3552 eleitores, realizada entre 08 e 09 de Novembro de 1990. Margem de erro e intervalo de confiança não disponibilizados.

\footnotetext{
${ }^{28}$ Maluf encerrou o primeiro turno em 1990 com 43,5\% dos votos válidos, percentual semelhante à sua votação e de Collor somadas em 1989.
} 
Quadro 4 - Preferência dos Eleitores por Grau de Escolaridade - Eleições para Governador (1990)

\begin{tabular}{lccc}
\hline $\begin{array}{c}\text { Candidato } \\
\text { (Partido) }\end{array}$ & Até $\mathbf{1}^{\mathbf{0}}$ Grau & $\mathbf{2}^{\mathbf{0}}$ Grau & Superior \\
\hline Maluf (PDS/PP) & $38 \%$ & $37 \%$ & $30 \%$ \\
\hline Fleury (PMDB) & $35 \%$ & $22 \%$ & $18 \%$ \\
Covas (PSDB) & $7 \%$ & $16 \%$ & $24 \%$ \\
Plínio (PT) & $5 \%$ & $13 \%$ & $18 \%$ \\
\hline
\end{tabular}

Fonte: Datafolha. Idem.

$\mathrm{Na}$ eleição para governador de 1990, passaram para o segundo turno os candidatos dos dois partidos oriundos do bipartidarismo imposto pelo Regime Militar. Por um lado, Maluf (PDS/PP) obtinha um robusto apoio popular entre os setores de menor renda e escolaridade. Sua preferência mantinha-se em patamares semelhantes em todos os níveis de renda e sofria decréscimo entre os eleitores mais escolarizados. Fleury (PMDB), por sua vez, apresentava resultados decrescentes à medida que aumentavam os índices de escolaridade e renda da amostra do eleitorado. A "sigla mágica" (pe)emedebista, como se vê, mantinha sua força nos setores populares, esteio das votações expressivas do então MDB nas eleições bipartidárias dos anos 1970 (LAMOUNIER, 1980).

Para o PSDB (dissidência peemedebista) e o PT, restava o desafio da popularização. Ambos possuíam índices crescentes de apoio na amostra selecionada à medida em que cresciam os índices de escolaridade e renda. Covas chega a obter um quarto das preferências entre os eleitores de nível superior de ensino, mas não chega a dois dígitos seu percentual de apoio entre os eleitores de menor escolaridade.

Este panorama modifica-se no pleito seguinte. As eleições de 1994 inauguram uma nova organização do calendário político nacional (e vigente desde então), com a realização de sufrágios concomitantes em nível federal e estadual nos cargos de 
presidente da República, senador (naquele ano, com renovação de duas das três vagas de cada Estado), deputados federais, governadores e deputados estaduais.

Neste pleito, o PSDB obtém os resultados eleitorais mais expressivos desde sua fundação em 1988: Fernando Henrique Cardoso vence as eleições presidenciais ${ }^{29}$ em primeiro turno e os tucanos conquistam seis governos de Estado (São Paulo, Minas Gerais, Rio de Janeiro, Ceará, Sergipe e Pará), além de uma bancada de nove senadores e 62 deputados federais.

Mais uma vez, observemos os índices de intenção de voto estratificados por escolaridade e renda:

Quadro 5- Preferência dos Eleitores por Renda Familiar Mensal - Eleições para Governador (1994) - $1^{\circ}$ Turno

\begin{tabular}{lcccc}
\hline $\begin{array}{c}\text { Candidato } \\
\text { (Partido) }\end{array}$ & $\begin{array}{c}\text { Até 2 Salários } \\
\text { Mínimos }\end{array}$ & $\begin{array}{c}\text { 2 a 5 Salários } \\
\text { Mínimos }\end{array}$ & $\begin{array}{c}\text { 5 a 10 Salários } \\
\text { Mínimos }\end{array}$ & $\begin{array}{c}\text { > 10 Salários } \\
\text { Mínimos }\end{array}$ \\
\hline Covas (PSDB) & $44 \%$ & $48 \%$ & $44 \%$ & $49 \%$ \\
Rossi (PDT) & $11 \%$ & $13 \%$ & $19 \%$ & $18 \%$ \\
Dirceu (PT) & $7 \%$ & $9 \%$ & $10 \%$ & $12 \%$ \\
$\begin{array}{l}\text { Munhoz } \\
\text { (PMDB) }\end{array}$ & $13 \%$ & $10 \%$ & $11 \%$ & $8 \%$ \\
\hline
\end{tabular}

Fonte: Datafolha. Pesquisa com amostra nacional de 21292 eleitores, realizada entre 27 e 28 de Setembro de 1994. Margem de erro e intervalo de confiança não disponibilizados. Dados referentes ao Estado de São Paulo.

\footnotetext{
${ }^{29}$ Sobre as eleições presidenciais de 1994, ver SINGER (1999) e BALBACHEVSKY e HOLZHACKER (2004).
} 
Quadro 6- Preferência dos Eleitores por Grau de Escolaridade - Eleições para

Governador (1994) - $1^{\circ}$ Turno

\begin{tabular}{lccc}
\hline $\begin{array}{c}\text { Candidato } \\
\text { (Partido) }\end{array}$ & Até $\mathbf{1}^{\mathbf{0}}$ Grau & $\mathbf{2}^{\mathbf{0}}$ Grau & Superior \\
\hline Covas (PSDB) & $44 \%$ & $48 \%$ & $51 \%$ \\
\hline Rossi (PDT) & $15 \%$ & $18 \%$ & $17 \%$ \\
\hline Dirceu (PT) & $7 \%$ & $12 \%$ & $18 \%$ \\
Munhoz (PMDB) & $12 \%$ & $7 \%$ & $3 \%$ \\
\hline
\end{tabular}

Fonte: Datafolha. Idem.

Nos dados apresentados nos quadros anteriores podemos identificar que o candidato tucano em São Paulo (e futuro governador), Mario Covas, aparece com larga margem em todos os grupos selecionados por renda, sem maiores oscilações nas diferentes faixas. Em relação à escolaridade, novamente o candidato tucano obtém maior apoio entre os eleitores com maior grau de instrução.

Já o candidato petista, José Dirceu, apresenta quadro semelhante ao pleito de quatro anos antes: seus índices de intenção de voto aumentam na medida em que crescem os níveis de escolaridade e renda da amostra. Digna de nota também é a decadência do candidato situacionista do PMDB, Barros Munhoz: o expressivo apoio popular obtido pelo PMDB ao longo da década de 1980 parecia dissipar-se após três mandatos à frente do governo paulista ${ }^{30}$. De qualquer maneira, o partido mantinha seus bastiões de maior apoio entre os setores de menor escolaridade e renda.

As pesquisas de intenção de voto selecionadas apontam diferenciação no padrão de votação do candidato do PDT, Francisco Rossi, apenas em termos de renda no primeiro turno. Anteriormente, elaboramos testes de correlação entre o voto do candidato e o nível de desenvolvimento socioeconômico dos municípios. Verificamos

\footnotetext{
${ }^{30}$ Em trabalho referente ao PMDB paulista, Fernando Bizarro Netto (2013) aponta alguns fatores para a decadência da outrora mais importante agremiação partidária do Estado; primeiramente, a "presidencialização" da política paulista ocorrida a partir de 1994 (com a emergência de um embate entre PT e PSDB e a decadência do conflito entre democracia e autoritarismo do fim do Regime Militar) e a própria estrutura organizativa do partido, focada em estruturas locais e na liderança do ex-governador Quércia.
} 
que havia correlação negativa significativa (ainda que de pequena magnitude) entre os índices de votação do candidato pedetista e o nível de desenvolvimento dos municípios, bem como positiva para o tamanho dos municípios ${ }^{31}$. Assim, é muito provável que a passagem de Rossi (por estreita margem) ao segundo turno tenha se dado em função de sua maior penetração nas camadas populares urbanas. Esta conjectura é coerente com o cenário eleitoral que se apresentava - afinal, pela primeira vez desde 1986 o expoente mais destacado do conservadorismo paulista, Paulo Maluf (PDS/PP), encontrava-se fora da disputa.

No segundo turno, os dados apresentados nos quadros a seguir denotam diferenças mais expressivas de bases sociais dos candidatos (sobretudo de Rossi):

\section{Quadro 7- Preferência dos Eleitores por Renda Familiar Mensal - Eleições para Governador (1994) - $2^{\circ}$ Turno}

\begin{tabular}{cccc}
\hline $\begin{array}{c}\text { Candidato } \\
\text { (Partido) }\end{array}$ & $\begin{array}{c}\text { Até 5 Salários } \\
\text { Mínimos }\end{array}$ & $\begin{array}{c}\mathbf{5} \text { a 10 Salários } \\
\text { Mínimos }\end{array}$ & $\begin{array}{c}>\text { 10 Salários } \\
\text { Mínimos }\end{array}$ \\
\hline Covas (PSDB) & $49 \%$ & $50 \%$ & $55 \%$ \\
Rossi (PDT) & $34 \%$ & $37 \%$ & $31 \%$
\end{tabular}

Fonte: Folha de São Paulo (12/11/1994). Informações metodológicas da pesquisa não disponibilizadas.

\footnotetext{
${ }^{31}$ Os índices encontrados, elaborados a partir de dados do TSE e da Fundação SEADE ao nível municipal, foram os seguintes (todos eles significativos a 1\%): tamanho do município: 0,291; taxa de analfabetismo: -0,288; Taxa de esgotamento: -0,238 (FIORE; 2014). É perceptível que este perfil não coaduna com as pesquisas estratificadas por renda no primeiro turno. Acreditamos, porém, que a ausência de Maluf neste pleito (o único em que o líder conservador não esteve presente entre 1986 e 2002) pode ter influenciado na volatilidade do eleitorado.
} 
Quadro 8- Preferência dos Eleitores por Grau de Escolaridade - Eleições para Governador (1994) - $2^{\circ}$ Turno

\begin{tabular}{cccc}
\hline $\begin{array}{c}\text { Candidato } \\
\text { (Partido) }\end{array}$ & Até 1 ${ }^{\mathbf{0}}$ Grau & $\mathbf{2}^{\mathbf{0}}$ Grau & Superior \\
\hline Covas (PSDB) & $49 \%$ & $49 \%$ & $59 \%$ \\
Rossi (PDT) & $35 \%$ & $36 \%$ & $23 \%$ \\
\hline
\end{tabular}

Fonte: Datafolha. Idem.

Como se vê, Covas (PSDB) mantém considerável apoio entre os eleitores de baixa renda e escolaridade, com aumento da preferência à medida em que avança o grau de instrução e renda dos eleitores (aumento este mais acentuado entre os eleitores de ensino superior). Já para Rossi, as sondagens eleitorais de segundo turno parecem mostrar um cenário mais claro do perfil popular de sua candidatura quando estratificados os entrevistados por grau de escolaridade - o candidato pedetista possui apoio consideravelmente menor entre os eleitores com ensino superior.

Quatro anos depois, porém, Mario Covas enfrentaria um cenário muito mais difícil em sua tentativa de reeleição. Não dispomos, para este pleito, de pesquisas de intenção de voto estratificadas por renda. Deteremo-nos, assim, nos índices de preferência dos eleitores de acordo com o grau de escolaridade: 
Quadro 9- Preferência dos Eleitores por Grau de Escolaridade - Eleições para Governador (1998) - $1^{\circ}$ Turno

\begin{tabular}{lccc}
\hline \multicolumn{1}{c}{$\begin{array}{c}\text { Candidato } \\
\text { (Partido) }\end{array}$} & Até $\mathbf{1}^{\mathbf{0}}$ Grau & $\mathbf{2}^{\mathbf{0}}$ Grau & Superior \\
\hline Maluf (PDS/PP) & $32 \%$ & $31 \%$ & $26 \%$ \\
Covas (PSDB) & $15 \%$ & $16 \%$ & $28 \%$ \\
\hline Marta (PT) & $12 \%$ & $19 \%$ & $23 \%$ \\
\hline Rossi (PDT) & $19 \%$ & $20 \%$ & $11 \%$ \\
\hline Quércia (PMDB) & $8 \%$ & $5 \%$ & $2 \%$ \\
\hline
\end{tabular}

Fonte: Datafolha. Pesquisa com amostra estadual (SP) de 3542 eleitores, realizada em 02 de Outubro de 1998. Margem de erro e intervalo de confiança não disponibilizados.

De maneira invertida, é possível verificar que o PMDB não logrou recuperar-se quatro anos depois. Mesmo com a presença de sua principal liderança na disputa (o exgovernador Orestes Quércia), a candidatura do partido manteve o caráter coadjuvante. Curioso notar, porém, que a base social do partido, ainda que diminuta, mantém coerência: é entre os eleitores de menor escolaridade que o PMDB obtém seus maiores índices de preferência. De maneira análoga, Francisco Rossi (PDT) apresenta entre os eleitores de nível superior seu menor percentual de preferência (perfil análogo ao do segundo turno no pleito anterior).

Mais uma vez, PT e PSDB apresentam perfis semelhantes de bases sociais: notase uma crescente de preferências à medida em que avança o grau de instrução dos entrevistados - sendo Covas líder neste segmento. Maluf, por sua vez, obtém seu melhor desempenho entre os eleitores com ensino fundamental (é o líder neste segmento do eleitorado) e uma pequena queda entre os eleitores de ensino superior.

Após uma disputa renhida pelo segundo lugar com Marta (PT), Covas passa ao segundo turno para enfrentar o vencedor da primeira rodada, Paulo Maluf. Os índices de preferência dos eleitores no segundo turno, estratificados por escolaridade e renda, são apresentados a seguir: 
Quadro 10 - Preferência dos Eleitores por Renda Familiar Mensal - Eleições para Governador (1998) - $2^{\circ}$ Turno

\begin{tabular}{lcccc}
\hline $\begin{array}{c}\text { Candidato } \\
\text { (Partido) }\end{array}$ & $\begin{array}{c}\text { Até 2 Salários } \\
\text { Mínimos }\end{array}$ & $\begin{array}{c}\text { 2 a 5 Salários } \\
\text { Mínimos }\end{array}$ & $\begin{array}{c}\text { 5 a 10 Salários } \\
\text { Mínimos }\end{array}$ & $\begin{array}{c}\text { > 10 Salários } \\
\text { Mínimos }\end{array}$ \\
\hline Covas (PSDB) & $44 \%$ & $50 \%$ & $52 \%$ & $52 \%$ \\
$\begin{array}{l}\text { Maluf } \\
\text { (PDS/PP) }\end{array}$ & $40 \%$ & $38 \%$ & $39 \%$ & $38 \%$ \\
\hline
\end{tabular}

Fonte: Datafolha. Pesquisa com amostra estadual (SP) de 4373 eleitores, realizada em 22 de Outubro de 1998. Margem de erro e intervalo de confiança não disponibilizados.

Quadro 11- Preferência dos Eleitores por Grau de Escolaridade - Eleições para Governador (1998) - $2^{\circ}$ Turno

\begin{tabular}{cccc}
\hline $\begin{array}{c}\text { Candidato } \\
\text { (Partido) }\end{array}$ & Até 10 Grau & $\mathbf{2}^{\mathbf{0}}$ Grau & Superior \\
\hline Covas (PSDB) & $46 \%$ & $52 \%$ & $60 \%$ \\
Maluf (PDS/PP) & $41 \%$ & $36 \%$ & $26 \%$ \\
\hline
\end{tabular}

Fonte: Datafolha. Idem.

Em termos de renda, ambos os candidatos possuíam um padrão de votação semelhante em todos os estratos - destaque-se que Covas possuía desempenho um pouco melhor à medida em que avançam os rendimentos familiares mensais dos entrevistados. Já em termos de escolaridade, o perfil de votação dos candidatos difere significativamente: enquanto entre os eleitores de ensino fundamental há quase empate, entre os entrevistados de nível superior Covas possui larga margem de preferências. Verifica-se, de maneira clara - assim como ocorrera quatro anos antes - um padrão inverso de votação entre Covas (maior preferência quanto maior a escolaridade) e seu adversário no segundo turno (maior apoio entre os segmentos de menor instrução da amostra). 
Importante frisar, assim, os aspectos mais relevantes desta seção: tanto PSDB quanto PT possuíam, ao longo da década de 1990, características de votação em certo sentido semelhantes: de acordo com pesquisas eleitorais estratificadas por renda e escolaridade $^{32}$, ambos os partidos obtinham, de maneira geral, melhor desempenho entre os eleitores de melhor renda e escolaridade. Excetuada a eleição de 1994, quando no primeiro turno o partido tucano consegue obter performance elevada e homogênea em todos os estratos das amostras ${ }^{33}$, é preponderante o crescimento de apoio ao PSDB em relação direta com o nível de escolaridade e renda das diferentes amostras - ainda que seja importante ressaltar o apoio considerável ao partido entre os setores populares do eleitorado.

\section{Eleições 2002: Continuidades ou Rupturas?}

Conforme mencionado no princípio deste capítulo, as eleições gerais de 2002 marcam uma inflexão na vida política brasileira com a chegada do PT ao governo central. Neste mesmo ano, o PT conseguiu seu feito mais significativo no Estado de São Paulo: pela primeira vez (e única, até o momento) logrou passar ao segundo turno nas eleições estaduais, protagonizando um duplo embate com o PSDB em nível local e nacional.

Em nível federal, conforme citado no início deste capítulo, o padrão de votação dos partidos até 2002 dava-se da seguinte forma: certa homogeneidade na distribuição de preferências dos candidatos do PSDB nos diferentes estratos de renda e, para o PT, uma escala crescente de suporte à medida em que se elevava o rendimento médio dos eleitores. Os dados das pesquisas eleitorais para 2002 apontam nesse sentido:

\footnotetext{
${ }^{32}$ Vale destacar que as pesquisas estratificadas por escolaridade apresentam variações entre as amostras maiores do que as pesquisas por renda. Não temos elementos para identificar as razões desta diferença, mas levantamos algumas hipóteses: as dificuldades maiores dos entrevistados em quantificar de maneira precisa o nível de renda familiar (ao contrário do nível de escolaridade) e as diferenças não desprezíveis entre um eleitor rico/pobre e escolarizado/não escolarizado. Para efeitos deste trabalho e a despeito da menor precisão metodológica, adotamos ambos os conceitos como intercambiáveis, uma vez que o foco principal assenta-se na tentativa de compreender as variações de apoio aos partidos de acordo com características socioeconômicas do eleitorado.

${ }^{33}$ Não está clara a razão desta oscilação neste pleito. Pode-se inferir, por um lado, a grande aprovação popular ao plano Real (conforme citado anteriormente, nesta eleição o PSDB obtém seu melhor desempenho na história e elege, simultaneamente, presidente da República e três dos quatro governadores do Sudeste). Por outro lado, a ausência de uma candidatura de peso como a de Paulo Maluf (PDS/PP) pode ter influenciado as escolhas do campo "conservador popular". Trataremos brevemente deste tema na conclusão.
} 
Quadro 12- Preferência dos Eleitores por Renda Familiar Mensal - Eleições para Presidente (2002) $-1^{\circ}$ Turno

\begin{tabular}{lcccc}
\hline $\begin{array}{c}\text { Candidato } \\
\text { (Partido) }\end{array}$ & $\begin{array}{c}\text { Até 2 Salários } \\
\text { Mínimos }\end{array}$ & $\begin{array}{c}\text { 2 a 5 Salários } \\
\text { Mínimos }\end{array}$ & $\begin{array}{c}\text { 5 a 10 Salários } \\
\text { Mínimos }\end{array}$ & $\begin{array}{c}\text { > 10 Salários } \\
\text { Mínimos }\end{array}$ \\
\hline Lula (PT) & $43 \%$ & $46 \%$ & $50 \%$ & $50 \%$ \\
Serra (PSDB) & $19 \%$ & $20 \%$ & $17 \%$ & $22 \%$ \\
$\begin{array}{l}\text { Garotinho } \\
\text { (PSB) }\end{array}$ & $17 \%$ & $16 \%$ & $14 \%$ & $8 \%$ \\
Ciro (PPS) & $11 \%$ & $11 \%$ & $12 \%$ & $14 \%$ \\
\hline
\end{tabular}

Fonte: SINGER (2012), p. 229

Vimos na seção anterior que, no Estado de São Paulo, ambos os partidos (PSDB e PT) obtinham maior apoio nos setores de maior escolaridade e renda do eleitorado. Para além das análises das pesquisas de intenção de voto estratificadas por escolaridade e renda, nesta seção analisaremos também os dados de votação dos principais candidatos associados à escolaridade média dos eleitores (quando do momento do cadastro eleitoral) para cada zona eleitoral ou município (menor unidade de análise ${ }^{34}$ ). Na cidade de São Paulo, por exemplo, compartilham do mesmo município bairros e distritos com padrões elevados de desenvolvimento humano (Jardins, Pinheiros e Moema, por exemplo) e outros com carências significativas (Capão Redondo, Jardim Ângela e Itaim Paulista, em outro exemplo). Neste sentido, procuramos encontrar uma unidade analítica mais próxima da realidade dos eleitores e, ainda que com limitações, buscar superar o problema da falácia ecológica ${ }^{35}$.

Para tanto, a partir de dados do cadastro do Tribunal Superior Eleitoral, calculamos um índice de escolaridade ponderado médio de cada unidade geográfica (zona ou município). Hipoteticamente, uma zona eleitoral cujos eleitores teriam todos

\footnotetext{
${ }^{34}$ A cidade de São Paulo, por exemplo, contém diversas zonas em sua circunscrição. O inverso também é verdadeiro: muitas zonas eleitorais no interior do Estado contêm diversos pequenos municípios.

${ }^{35}$ Trata-se aqui de não inferir a parte pela análise do todo. Por exemplo, é possível constatar que uma determinada localidade mais pobre votou majoritariamente em determinado candidato. Porém, requer maior cautela e passos empíricos adicionais afirmar que os mais pobres daquela localidade votam no referido candidato. Deve-se destacar, porém, que os estudos eleitorais sempre terão de conviver com alguma limitação metodológica nos marcos de uma democracia moderna, uma vez que a inviolabilidade do voto secreto é um de seus princípios basilares.
} 
ensino superior completo quando do momento de cadastramento (ou recadastramento) teria índice de 7 . Inversa e hipoteticamente, uma zona eleitoral cujos eleitores em sua totalidade fossem analfabetos teria índice $0^{36}$. Assim, foi possível classificar cada zona eleitoral ou município de acordo com sua escolaridade média e, paralelamente, verificar o desempenho dos partidos nestas mesmas localidades. Assim, procuramos estabelecer uma relação entre o padrão de desenvolvimento da unidade de análise e a votação dos principais partidos.

Após estabelecermos os índices para cada município ou zona, ordenamos as unidades de acordo com sua escolaridade média (da menor para maior). Assim, no pleito de 2002 identificamos que a unidade com menor escolaridade média dos eleitores foi o município de Barra do Turvo (índice de 1,54), localizado no Vale do Ribeira. Na outra ponta da tabela, a zona eleitoral 108, localizada no centro do município de Ribeirão Preto, obteve a maior escolaridade média de eleitores (índice de 4,82).

Por sua importância eleitoral (corresponde a um quarto dos eleitores do Estado), convém citarmos rapidamente os índices médios da capital. As três zonas paulistanas com menor escolaridade foram, pela ordem, 372 - Jardim Ângela, 371 - Grajaú e 352 Itaim Paulista (com índices, respectivamente, de 2,53; 2,54; e 2,60). Na parte superior da tabela, as três primeiras colocadas foram 005 - Jardim Paulista, 251 - Pinheiros e 258 - Indianópolis (com índices, respectivamente, de 4,80; 4,73; e 4,64). As localidades citadas (a menor ou a maior) são reconhecidas pelas desigualdades que as marcam. Verifica-se, assim, que o índice permitiu estabelecer uma diferenciação compatível com

\footnotetext{
${ }^{36}$ Quando do cadastramento eleitoral (ou recadastramento) em um Cartório Eleitoral, o (a) eleitor (a) é instado a informar seu grau de escolaridade a partir das seguintes opções (em parênteses, a classificação numérica que atribuímos a cada índice): "Analfabeto" (0), "Lê e Escreve" (1), Primeiro Grau Incompleto" (2), "Primeiro Grau Completo" (3) "Segundo Grau Incompleto" (4), "Segundo Grau Completo" (5), "Superior Incompleto" (6) e "Superior Completo" (7). Os casos não informados foram classificados também como (0) - sendo, porém, pouco significativos (em 2002, por exemplo, foram apenas 30 casos em um universo de mais de 25,6 milhões de eleitores). Estamos cientes de que parcela expressiva do eleitorado não atualiza seus dados cadastrais. É possível, por exemplo, que um eleitor atualmente com ensino superior completo conste na base de dados com nível de escolaridade média incompleta se efetuou sua inscrição aos dezesseis anos. Ainda assim, observamos no gráfico 2 que, em São Paulo, apenas 15\% da população possui 15 anos ou mais de estudo atualmente. Desse modo, as informações de escolaridade, ainda que parciais, permitem a segmentação do eleitorado atualmente. $\mathrm{O}$ avanço da escolaridade média da população, porém, tende a tornar o índice mais homogêneo ao longo do tempo - logo, com menor capacidade de segmentação dos eleitores e suas localidades geográficas.
} 
a realidade social efetiva das unidades de análise (e num mesmo campo geográfico que possibilita a aferição do desempenho dos $\operatorname{partidos}^{37}$ ).

Elaborada a classificação das unidades pela escolaridade média dos eleitores, dividimos as mesmas em decis. De forma a tornar mais didática a apresentação dos resultados, agregamos cada decil de escolaridade em um mesmo bloco e calculamos o índice médio de votação dos partidos para cada décimo de escolaridade médio. Os resultados para o pleito de 2002 encontram-se no gráfico a seguir ${ }^{38}$ :

\footnotetext{
${ }^{37}$ Há indicadores mais precisos de mensuração socioeconômica dos habitantes em nível intramunicipal (como subprefeituras, distritos, setores censitários, entre outros). Porém, a organização regional utilizada pelo TSE (ou TRE, no caso paulista) de zonas e seções eleitorais é utilizada tão somente pelo mesmo, sendo possível apenas conjugar padrões de votação com indicadores de desenvolvimento ao nível municipal - o que, como mencionamos, muitas vezes desconsidera as importantes variações internas de cada cidade.

${ }^{38}$ Nesta eleição, o PMDB lançou como candidato Lamartine Posella, quadro de menor expressão que substituiu Fernando Morais no meio da disputa e que, ao final do pleito, teve meros 1,32\% do total de votos válidos. A maior liderança do partido, Orestes Quércia, candidatou-se ao Senado - sendo a candidatura de Posella mais uma plataforma adicional de suporte à sua busca pela cadeira no parlamento federal e menos uma opção viável ao governo do Estado (BIZARRO NETO, 2013, p. 112). Por esta razão, não conferimos maior destaque à candidatura do PMDB neste pleito.
} 


\section{Gráfico 3- Percentual Médio de Votos Válidos por Decil de Escolaridade das Zonas Eleitorais ou Municípios - $\mathbf{1}^{\circ}$ Turno - 2002}

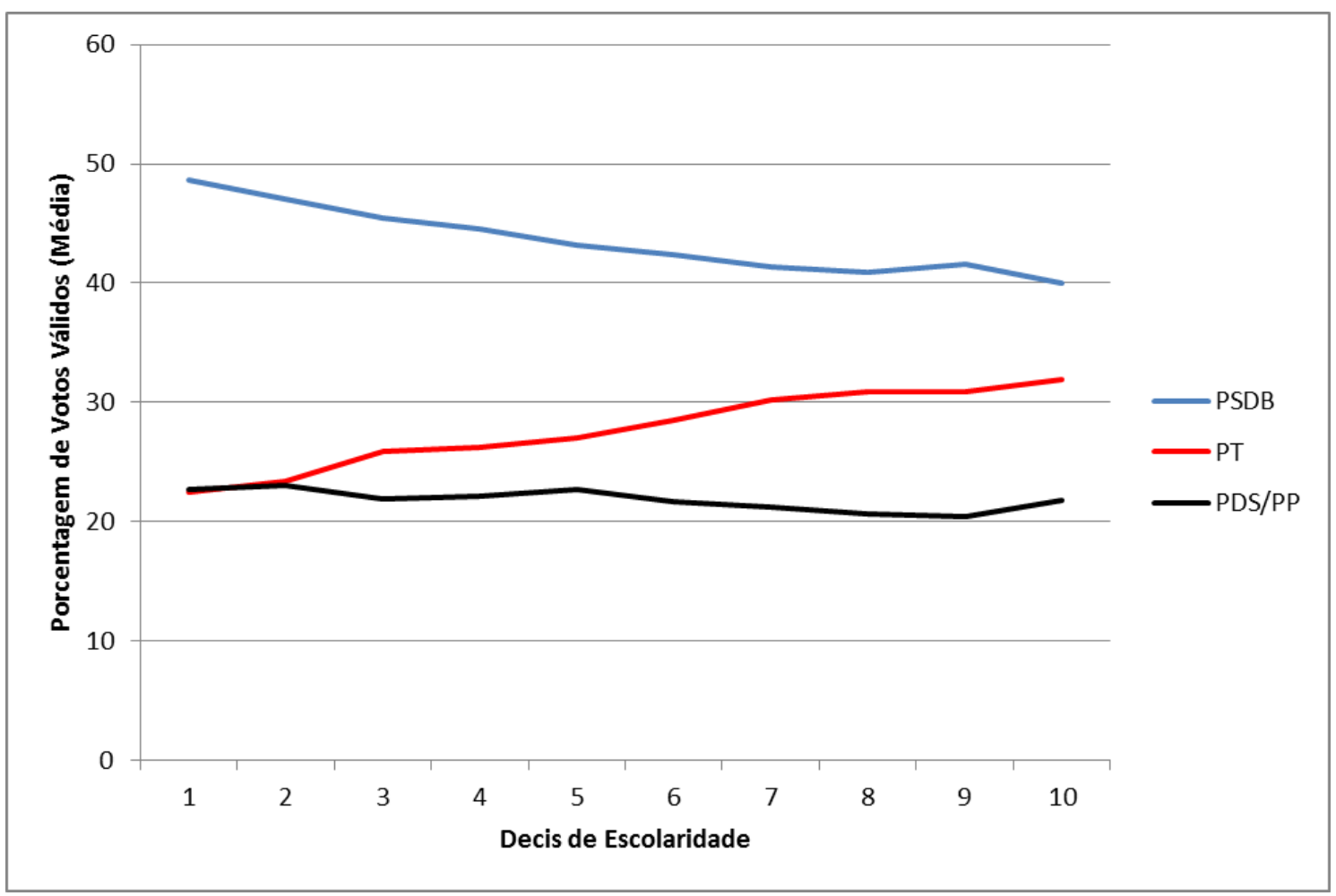

Fonte: TSE

Ao analisarmos os dados, verificamos que Paulo Maluf (PDS/PP) mantém um índice de votação médio homogêneo ao longo de todos os decis de escolaridade levantados. Assim, o candidato parece ter distribuição semelhante ao longo da amostra, com tendência de leve apoio médio maior entre os eleitores dos extremos (menor e maior escolaridade).

O candidato do PT, por sua feita, obtém uma distribuição de votos semelhante ao padrão histórico do partido no Estado: maior índice de sufrágio à medida em que aumentam os índices de desenvolvimento médio das localidades. Este perfil, ressalte-se, coaduna com o encontrado pela literatura em âmbito nacional para o pleito de 2002, conforme citado na seção introdutória deste capítulo. Em outras palavras, em 2002 o PT mantinha-se como um partido de maior penetração nos locais mais desenvolvidos do Estado.

A análise dos dados do PSDB, por sua vez, aponta para um cenário oposto ao que historicamente associava-se ao partido. A candidatura à reeleição de Geraldo Alckmin obteve maiores índices médios de votação na medida em que decresciam os 
índices médios de escolaridade dos eleitores, atingindo o seu ápice no primeiro decil. Pela primeira vez, o PSDB apresentava um perfil de votação mais identificado com eleitores de menor escolaridade.

De forma a checar a validade dos dados acima, analisamos novamente as pesquisas eleitorais estratificadas por escolaridade e renda para o pleito de 2002. Os dados seguem apresentados nos quadros a seguir:

Quadro 13- Preferência dos Eleitores por Renda Familiar Mensal - Eleições para Governador (2002) - $1^{\circ}$ Turno

\begin{tabular}{lcccc}
\hline \multicolumn{1}{c}{$\begin{array}{c}\text { Candidato } \\
\text { (Partido) }\end{array}$} & $\begin{array}{c}\text { Até 2 Salários } \\
\text { Mínimos }\end{array}$ & $\begin{array}{c}\text { 2 a 5 Salários } \\
\text { Mínimos }\end{array}$ & $\begin{array}{c}\text { 5 a 10 Salários } \\
\text { Mínimos }\end{array}$ & $\begin{array}{c}\text { > 10 Salários } \\
\text { Mínimos }\end{array}$ \\
\hline $\begin{array}{l}\text { Alckmin } \\
\text { (PSDB) }\end{array}$ & $30 \%$ & $37 \%$ & $36 \%$ & $40 \%$ \\
Genoino (PT) & $14 \%$ & $20 \%$ & $25 \%$ & $26 \%$ \\
Maluf (PDS/PP) & $28 \%$ & $26 \%$ & $25 \%$ & $23 \%$ \\
\hline
\end{tabular}

Fonte: Datafolha. Pesquisa com amostra estadual (SP) de 3713 eleitores, realizada entre 04 e 05 de Outubro de 2002. Margem de erro de 2 p.p. e intervalo de confiança de $95 \%$.

Quadro 14 - Preferência dos Eleitores por Grau de Escolaridade - Eleições para Governador (2002) - $1^{\circ}$ Turno

\begin{tabular}{cccc}
\hline $\begin{array}{c}\text { Candidato } \\
\text { (Partido) }\end{array}$ & Até 1 $\mathbf{1}^{\mathbf{0}}$ Grau & $\mathbf{2}^{\mathbf{0}}$ Grau & Superior \\
\hline Alckmin (PSDB) & $36 \%$ & $39 \%$ & $35 \%$ \\
Genoino (PT) & $17 \%$ & $25 \%$ & $35 \%$ \\
Maluf (PDS/PP) & $27 \%$ & $21 \%$ & $18 \%$ \\
\hline
\end{tabular}

Fonte: Datafolha. Idem.

Nota-se que, em relação ao PT, as pesquisas eleitorais corroboram os achados anteriores: o apoio a José Genoino aumentava à medida em que se elevavam os níveis 
de escolaridade e renda da amostra. Nesse sentido, é seguro afirmar que o PT, até 2002, era um partido com apoios mais relevantes nas classes média e alta do eleitorado.

Os dados referentes a Maluf, por sua vez, são menos conclusivos. Em termos de renda, o candidato de fato possui uma ligeira vantagem nos segmentos mais baixos da amostra. Porém, a amostra estratificada por escolaridade mostrou um apoio mais robusto ao candidato do PDS/PP nos segmentos menos escolarizados, situação essa mostrada de forma mais "suave" quando analisados os dados eleitorais vis-à-vis a escolaridade média dos eleitores.

Já em relação ao PSDB, os dados mostram diferenças em relação aos resultados eleitorais encontrados. Por um lado, a pesquisa estratificada por renda apresenta um perfil oposto ao encontrado nos resultados eleitorais: Alckmin apresenta um índice de votação maior à medida em que aumenta a renda média da amostra. Em relação à escolaridade, há certa homogeneidade nos resultados encontrados entre os diferentes estratos, com o candidato tucano obtendo cerca de um terço das preferências nos diferentes segmentos.

No segundo turno, na medida em que utilizamos o percentual de votos válidos fornecidos pelo TSE, a curva de votação média dos dois partidos representa uma curva invertida simétrica em relação um ao outro - afinal, o não-voto em um significa necessariamente o voto em outro. Conforme podemos identificar no gráfico abaixo, é possível identificar tendência inversa nas bases de maior sustentação média dos partidos: 


\section{Gráfico 4 - Percentual Médio de Votos Válidos por Decil de Escolaridade das}

Zonas Eleitorais e Municípios - 20 Turno - 2002

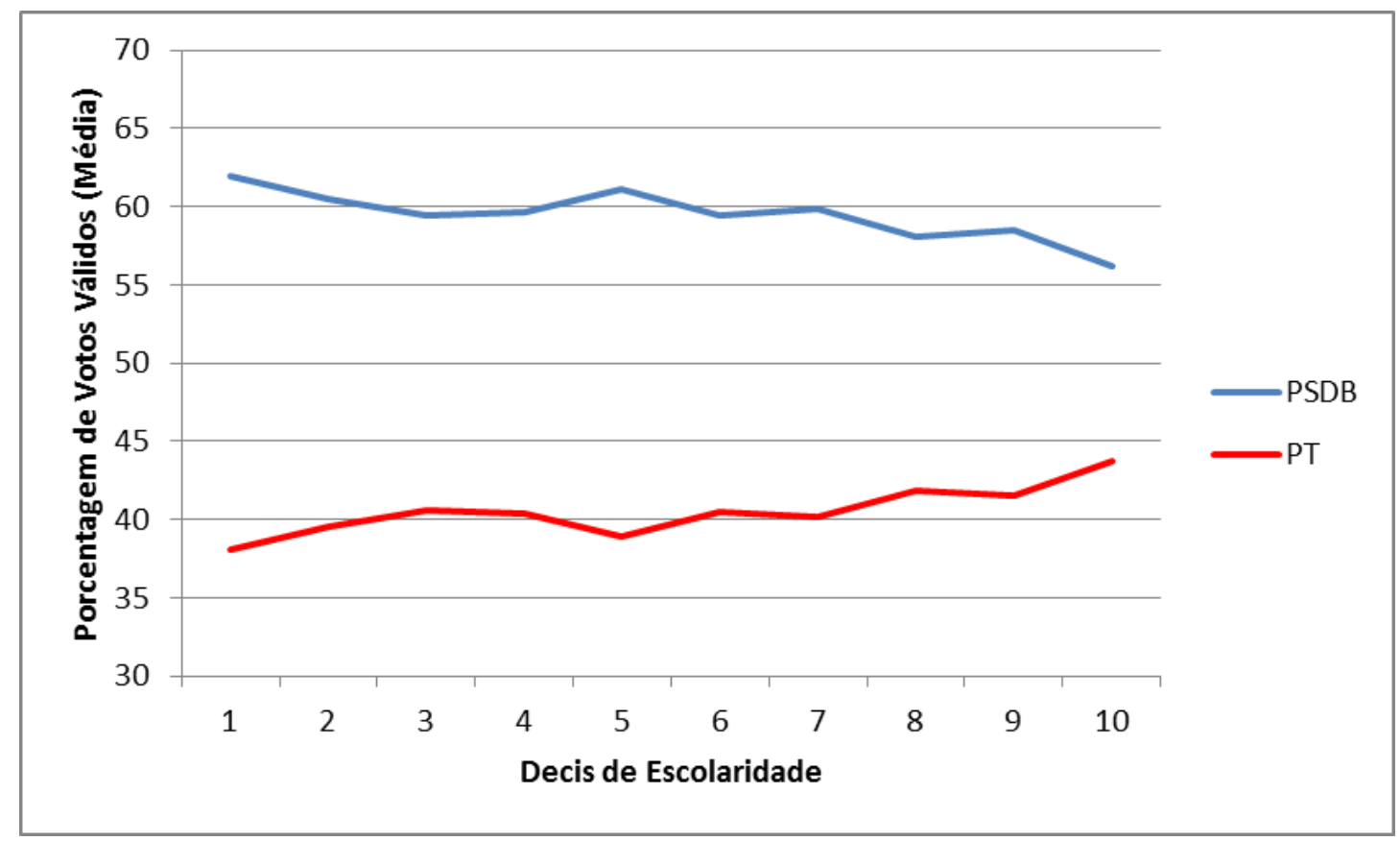

Fonte: TSE

Como se vê, o PT repete sua mesma trajetória do turno anterior (e histórica no Estado de São Paulo): o partido obtém sua maior votação média no último decil de escolaridade e sua mais baixa votação média no primeiro decil. O PSDB, inversamente e em consonância com os resultados do primeiro turno, consegue suas maiores votações média nos locais com maior número de eleitores de baixa escolaridade.

As pesquisas eleitorais da época, porém, apresentaram um resultado mais homogêneo na distribuição de votos entre os partidos de acordo com os diferentes estratos da amostra, conforme os quadros a seguir: 
Quadro 15 - Preferência dos Eleitores por Renda Familiar Mensal - Eleições para Governador (2002) - $2^{\circ}$ Turno

\begin{tabular}{lccc}
\hline $\begin{array}{c}\text { Candidato } \\
\text { (Partido) }\end{array}$ & $\begin{array}{c}\text { Até 5 Salários } \\
\text { Mínimos }\end{array}$ & $\begin{array}{c}\text { 5 a 10 Salários } \\
\text { Mínimos }\end{array}$ & $\begin{array}{c}>\text { 10 Salários } \\
\text { Mínimos }\end{array}$ \\
\hline $\begin{array}{l}\text { Alckmin } \\
\text { (PSDB) }\end{array}$ & $54 \%$ & $52 \%$ & $57 \%$ \\
Genoino (PT) & $37 \%$ & $42 \%$ & $37 \%$
\end{tabular}

Fonte: Datafolha. Pesquisa com amostra estadual (SP) de 4497 eleitores, realizada em 23 de Outubro de 2002. Margem de erro de 2 p.p. e intervalo de confiança de $95 \%$.

Quadro 16- Preferência dos Eleitores por Grau de Escolaridade - Eleições para Governador (2002) - $2^{\circ}$ Turno

\begin{tabular}{cccc}
\hline $\begin{array}{c}\text { Candidato } \\
\text { (Partido) }\end{array}$ & Até 10 Grau & $\mathbf{2}^{\mathbf{0}}$ Grau & Superior \\
\hline Alckmin (PSDB) & $56 \%$ & $53 \%$ & $56 \%$ \\
Genoino (PT) & $37 \%$ & $37 \%$ & $39 \%$ \\
\hline
\end{tabular}

Fonte: Datafolha. Idem.

Mais uma vez, encontramos diferenças entre os resultados eleitorais analisados de acordo com a escolaridade média dos eleitores e as sondagens de opinião estratificadas por instrução e renda. Dado o histórico de votação das candidaturas em pleitos anteriores, bem como a análise dos resultados do primeiro turno, parece mais razoável supor que a distribuição de votação entre os partidos seguiu um padrão mais semelhante ao apresentado no gráfico 4. Teria-se, assim, um cenário de votação em São Paulo que, em 2002, espelha os padrões de votação encontrados pela literatura em nível nacional até este pleito.

\section{Eleições 2006 - Rupturas e Continuidades Não Esperadas}

As eleições gerais de 2006 marcariam, em âmbito nacional, o momento em que as bases sociais de votação dos principais partidos brasileiros - PT e PSDB - passariam 
a contar com contornos nítidos e inversos em termos do padrão socioeconômico dos eleitores. Significariam, ademais, uma inflexão no padrão de votação do PT, que passaria a contar pela primeira vez com maior apoio entre os segmentos mais populares do eleitorado (o inverso para o PSDB). As pesquisas eleitorais em âmbito nacional apontam para este cenário:

Quadro 17- Preferência dos Eleitores por Renda Familiar Mensal - Eleições para Presidente (2006) - $1^{\circ}$ Turno

\begin{tabular}{lcccc}
\hline \multicolumn{1}{c}{$\begin{array}{c}\text { Candidato } \\
\text { (Partido) }\end{array}$} & $\begin{array}{c}\text { Até 2 Salários } \\
\text { Mínimos }\end{array}$ & $\begin{array}{c}\text { 2 a 5 Salários } \\
\text { Mínimos }\end{array}$ & $\begin{array}{c}\text { 5 a 10 Salários } \\
\text { Mínimos }\end{array}$ & $\begin{array}{c}\text { > 10 Salários } \\
\text { Mínimos }\end{array}$ \\
\hline $\begin{array}{l}\text { Lula (PT) } \\
\text { Alckmin (PSDB) }\end{array}$ & $28 \%$ & $41 \%$ & $30 \%$ & $29 \%$ \\
$\begin{array}{l}\text { Heloisa Helena } \\
\text { (PSOL) }\end{array}$ & $6 \%$ & $98 \%$ & $45 \%$ & $44 \%$ \\
$\begin{array}{l}\text { Cristovam } \\
\text { (PDT) }\end{array}$ & $1 \%$ & $3 \%$ & $14 \%$ & $11 \%$ \\
\hline
\end{tabular}

Fonte: SINGER (2012), p. 55

No Estado de São Paulo, a eleição é polarizada desde o primeiro turno entre PT e PSDB (neste pleito, o PDS/PP não lançou candidato) e, de forma inédita desde 1990 (quando são estabelecidas as eleições em dois turnos), o candidato tucano consegue encerrar a disputa na primeira rodada de votações.

Uma vez mais, efetuamos a comparação de votação dos candidatos em relação ao grau médio de escolaridade do eleitorado ao nível das zonas eleitorais e municípios. Os resultados seguem apresentados no gráfico a seguir: 


\section{Gráfico 5- Percentual Médio de Votos Válidos por Decil de Escolaridade das Zonas Eleitorais - $\mathbf{1}^{\circ}$ Turno - 2006}

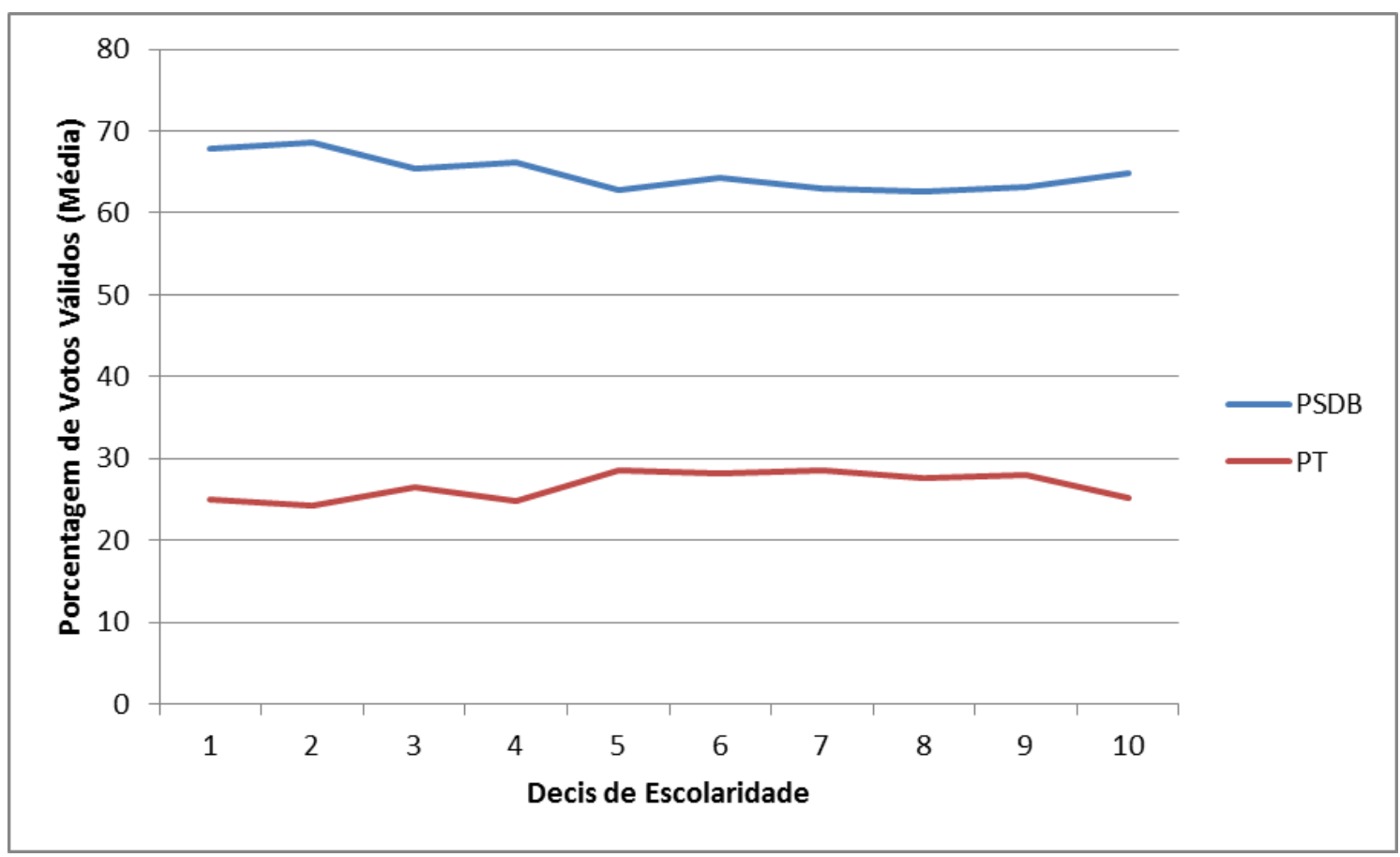

Fonte: TSE

Tanto PSDB quanto PT apresentam um padrão de votação que se poderia considerar relativamente homogêneo entre os diferentes decis de escolaridade. A candidatura tucana apresenta suas maiores proporções médias no primeiro e no segundo decil e cai à medida em que se avança a escolaridade média do eleitorado. No último decil, há um novo aumento de preferências. Perceba-se, porém, que em todos os estratos o partido manteve índices médios de votação acima de $60 \%$ dos votos válidos.

Já o PT, por sua vez e esperadamente, apresenta configuração inversa de médias de votação. Seus percentuais de votação crescem à medida em que avança o nível de escolaridade média dos eleitores (até o quinto decil, quando ocorre estabilidade), com um decréscimo relevante no último decil de comparação.

O que se verifica, assim, é que, no Estado de São Paulo, não ocorreu movimentação de bases sociais de maneira análoga à dinâmica estabelecida na disputa federal. O eleitorado situado nos locais de menor desenvolvimento econômico sufragou maciçamente o candidato do PSDB e não foi possível perceber movimentação ascendente da votação do partido conforme aumentavam os níveis de escolaridade 
média do eleitorado (convém frisar uma vez mais, padrão claramente distinto do encontrado nas disputas presidenciais brasileiras desde 2006).

De forma a checar a validade dos achados acima, comparamos os mesmos com os dados de pesquisas eleitorais estratificados por escolaridade e renda. Os dados seguem apresentados nos quadros a seguir:

Quadro 18- Preferência dos Eleitores por Renda Familiar Mensal - Eleições para Governador (2006) - $1^{\circ}$ Turno

\begin{tabular}{lcccc}
\hline $\begin{array}{c}\text { Candidato } \\
\text { (Partido) }\end{array}$ & $\begin{array}{c}\text { Até 2 Salários } \\
\text { Mínimos }\end{array}$ & $\begin{array}{c}\text { 2 a 5 Salários } \\
\text { Mínimos }\end{array}$ & $\begin{array}{c}\text { 5 a 10 Salários } \\
\text { Mínimos }\end{array}$ & $\begin{array}{c}\text { > 10 Salários } \\
\text { Mínimos }\end{array}$ \\
\hline Serra (PSDB) & $50 \%$ & $52 \%$ & $55 \%$ & $61 \%$ \\
$\begin{array}{l}\text { Mercadante } \\
\text { (PT) }\end{array}$ & $22 \%$ & $24 \%$ & $20 \%$ & $20 \%$ \\
$\begin{array}{l}\text { Quércia } \\
\text { (PMDB) }\end{array}$ & $11 \%$ & $08 \%$ & $07 \%$ & $05 \%$ \\
\hline
\end{tabular}

Fonte: Datafolha. Pesquisa com amostra estadual (SP) de 3219 eleitores, realizada entre 29 e 30 de Setembro de 2006. Margem de erro de 2 p.p. e intervalo de confiança de $95 \%$.

Quadro 19- Preferência dos Eleitores por Grau de Escolaridade - Eleições para Governador (2006) - $1^{\circ}$ Turno

\begin{tabular}{cccc}
\hline $\begin{array}{c}\text { Candidato } \\
\text { (Partido) }\end{array}$ & Até 10 Grau & $\mathbf{2}^{\mathbf{0}}$ Grau & Superior \\
\hline Serra (PSDB) & $53 \%$ & $52 \%$ & $55 \%$ \\
Mercadante (PT) & $21 \%$ & $24 \%$ & $21 \%$ \\
Quércia (PMDB) & $9 \%$ & $9 \%$ & $4 \%$ \\
\hline
\end{tabular}

Fonte: Datafolha. Idem. 
Primeiramente, um comentário sobre a candidatura peemedebista de Orestes Quércia. Naquela eleição, o ex-governador novamente obteve desempenho pouco expressivo (encerraria o pleito com menos de 5\% do total de votos válidos), mas é digna de nota a manutenção do perfil de votação do PMDB durante todo o período analisado até o momento neste capítulo: novamente, seu maior apoio advém das amostras de eleitores de menor escolaridade e renda, com preferência decrescente à medida em que avançam estes indicadores.

Em relação ao PT e PSDB, os dados das pesquisas estratificadas revelam um padrão muito semelhante ao encontrado nas análises das votações dos partidos apresentada no gráfico 5 acima. Não há diferenças de monta no apoio ao PT entre os diferentes estratos da amostra, e o predomínio do PSDB é expressivo também de forma relativamente homogênea em todos os segmentos (com elevação nos estratos de maior renda, o que o torna mais semelhante ao padrão nacional).

Neste sentido, pode-se dizer que as mudanças do perfil de votação esperadas para os partidos em São Paulo - se comparadas com o mesmo padrão de disputa em nível nacional - não ocorreram: o PT, de fato, não mais contava com apoio crescente dos eleitores à medida em que avançavam seus níveis médios de escolaridade e renda. Não obteve, porém, sufrágio expressivamente maior entre os eleitores dos estratos mais populares do eleitorado.

O PSDB, por sua vez, consolidava sua hegemonia eleitoral no Estado, com votações elevadas em todas as camadas sociais paulistas. Em outras palavras, o pleito estadual teve panorama diverso em relação ao pleito federal: não foi possível identificar bases sociais relevantes de suporte aos principais partidos em disputa.

\section{Eleições 2010 - Enfim o Realinhamento?}

Nas eleições de 2010, a despeito de não ter ocorrido segundo turno, o Partido dos Trabalhadores obteve seu maior percentual de votação em eleições estaduais em São Paulo. O PDS/PP volta a lançar-se neste pleito, mas seu candidato (Celso Russomano) ficou em um distante terceiro lugar.

Se nas eleições de 2006 não parecia haver maior diferenciação de bases sociais entre os principais candidatos, neste pleito passa a configurar-se - de maneira incipiente 
- um perfil mais característico de apoio aos partidos. Este movimento pode ser identificado no gráfico 6 a seguir:

Gráfico 6- Percentual Médio de Votos Válidos por Decil de Escolaridade das Zonas Eleitorais - $\mathbf{1}^{\circ}$ Turno - 2010

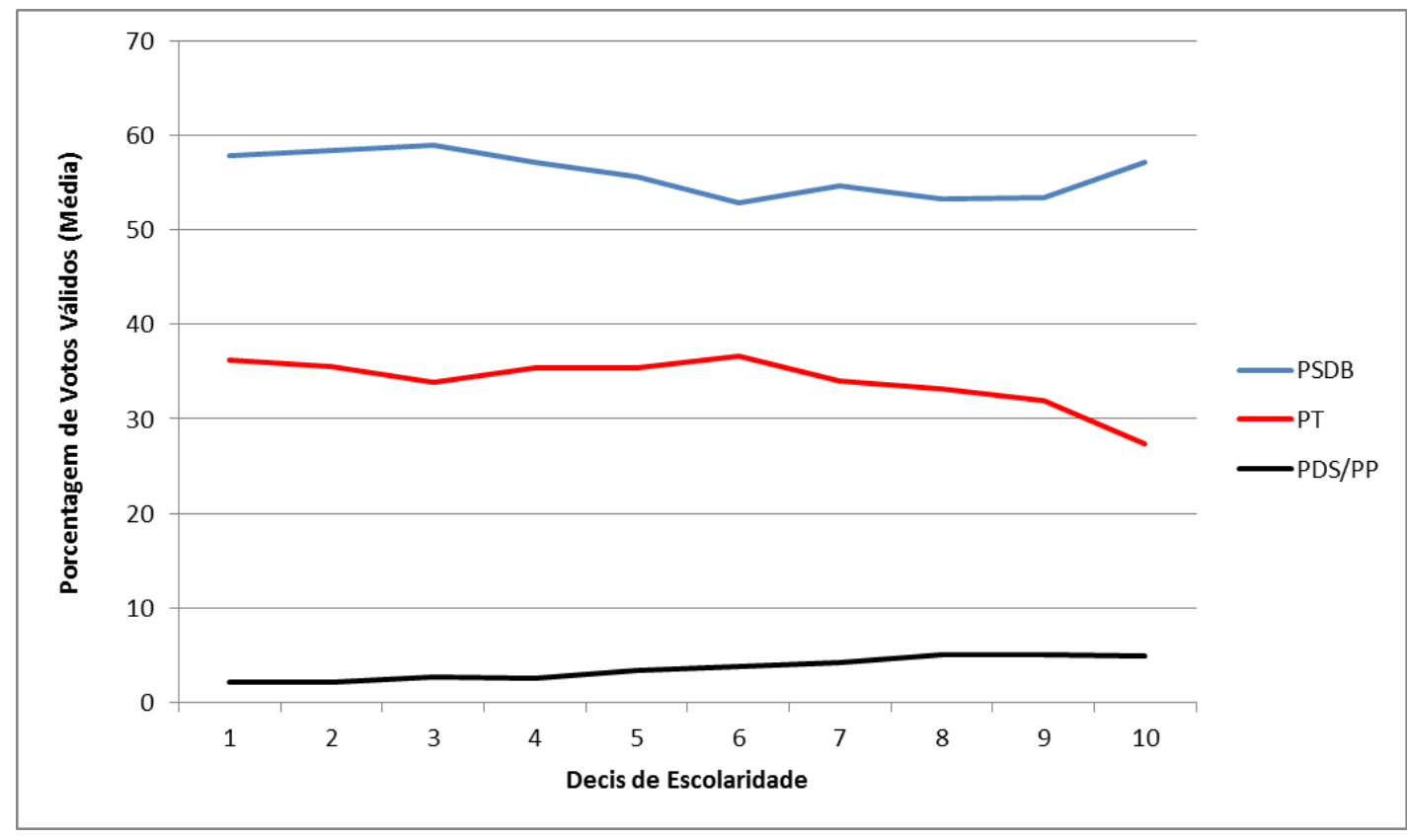

Fonte: TSE

A análise de votação conjugada com o padrão médio de escolaridade dos eleitores permite observar que o voto no PT torna-se mais propenso entre os eleitores do primeiro decil, atingindo seu menor patamar nos eleitores das localidades de maior escolaridade média. O PSDB, por sua vez, mantém um apoio significativo nos locais de menor escolaridade média e diminui sua votação na medida em que avançam os decis de escolaridade. A partir do sexto decil, porém, o partido volta a oscilar positivamente.

Neste sentido, é possível dizer que, nas eleições de 2010, delineou-se um cenário de votação em que as bases sociais de voto a PT e PSDB pareciam um pouco mais próximas ao panorama encontrado em nível nacional a partir de 2006. A própria vitória do PT em locais de maior vulnerabilidade social (regiões de baixo desenvolvimento econômico e franjas da região metropolitana) apontava nesse sentido ${ }^{39}$.

\footnotetext{
${ }^{39}$ O próprio governador reeleito assimilou este cenário. Em perfil publicado em dezembro de 2014 na Revista Piauí, logo após sua reeleição, citou o desempenho menos expressivo em certas regiões nas eleições de 2010: “(...) Alckmin se levantou da poltrona e pegou de cima de sua mesa um papel dobrado. Mostrou um mapa azul, pontuado por pequenas manchas vermelhas, ilustrando sua vitória sobre o PT em 594 das 645 cidades do estado na eleição de 2010. Excluindo a região metropolitana, as demais cidades onde o PSDB havia perdido tinham em comum a presença de assentamentos de reforma agrária". (Piauí,
} 
Nas eleições nacionais, conforme mencionado acima, a diferenciação de bases sociais entre PT e PSDB mantinha-se nos termos estabelecidos desde 2006, conforme apontam os dados da pesquisa de intenção de voto estratificados por renda e escolaridade:

Quadro 20- Preferência dos Eleitores por Renda Familiar Mensal - Eleições para Presidente (2010) $-1^{\circ}$ Turno

\begin{tabular}{|c|c|c|c|c|}
\hline $\begin{array}{l}\text { Candidato } \\
\text { (Partido) }\end{array}$ & $\begin{array}{c}\text { Até } 2 \text { Salários } \\
\text { Mínimos }\end{array}$ & $\begin{array}{c}2 \text { a } 5 \text { Salários } \\
\text { Mínimos }\end{array}$ & $\begin{array}{c}5 \text { a } 10 \text { Salários } \\
\text { Mínimos }\end{array}$ & $\begin{array}{c}\text { > } 10 \text { Salários } \\
\text { Mínimos }\end{array}$ \\
\hline Dilma (PT) & $53 \%$ & $43 \%$ & $37 \%$ & $31 \%$ \\
\hline Serra (PSDB) & $26 \%$ & $31 \%$ & $34 \%$ & $38 \%$ \\
\hline Marina (PV) & $12 \%$ & $19 \%$ & $22 \%$ & $23 \%$ \\
\hline \multicolumn{5}{|c|}{$\begin{array}{l}\text { Fonte: Datafolha. Pesquisa com amostra nacional de } 20960 \text { eleitores, realizada entre } 01 \\
\text { e } 02 \text { de Outubro de 2010. Margem de erro de } 2 \text { p.p. e intervalo de confiança de } 95 \% \\
\text { Quadro 21- Preferência dos Eleitores por Grau de Escolaridade - Eleições para } \\
\text { Presidente }(\mathbf{2 0 1 0})-\mathbf{1}^{\circ} \text { Turno }\end{array}$} \\
\hline $\begin{array}{c}\text { Candidato } \\
\text { (Partido) }\end{array}$ & Fundame & ntal & Médio & Superior \\
\hline$\overline{\text { Dilma (PT) }}$ & $52 \%$ & & $45 \%$ & $31 \%$ \\
\hline Serra (PSDB) & $28 \%$ & & $29 \%$ & $34 \%$ \\
\hline Marina (PV) & $10 \%$ & & $19 \%$ & $27 \%$ \\
\hline
\end{tabular}

Fonte: Datafolha. Idem.

Os dados das pesquisas eleitorais para governador do Estado de São Paulo, estratificados por renda e escolaridade, apontam para cenário semelhante em relação ao PSDB:

Edição 99, 2014, p. 18). Trataremos em pormenores da distribuição geográfica de votos no capítulo seguinte. 
Quadro 22- Preferência dos Eleitores por Renda Familiar Mensal - Eleições para Governador (2010) - $1^{0}$ Turno

\begin{tabular}{lcccc}
\hline \multicolumn{1}{c}{$\begin{array}{c}\text { Candidato } \\
\text { (Partido) }\end{array}$} & $\begin{array}{c}\text { Até 2 Salários } \\
\text { Mínimos }\end{array}$ & $\begin{array}{c}\text { 2 a 5 Salários } \\
\text { Mínimos }\end{array}$ & $\begin{array}{c}\mathbf{5} \text { a 10 Salários } \\
\text { Mínimos }\end{array}$ & $\begin{array}{c}>\text { 10 Salários } \\
\text { Mínimos }\end{array}$ \\
\hline $\begin{array}{l}\text { Alckmin (PSDB) } \\
\text { Mercadante }\end{array}$ & $48 \%$ & $50 \%$ & $53 \%$ & $57 \%$ \\
(PT) & $24 \%$ & $27 \%$ & $29 \%$ & $21 \%$ \\
Russomano & $10 \%$ & $09 \%$ & $07 \%$ & $05 \%$ \\
(PDS/PP) & & & & \\
\hline
\end{tabular}

Fonte: Datafolha. Pesquisa com amostra estadual (SP) de 3248 eleitores, realizada entre 01 e 02 de Outubro de 2010. Margem de erro de 2 p.p. e intervalo de confiança de $95 \%$.

Quadro 23 - Preferência dos Eleitores por Grau de Escolaridade - Eleições para Governador (2010) - $1^{\circ}$ Turno

\begin{tabular}{lccc}
\hline \multicolumn{1}{c}{$\begin{array}{c}\text { Candidato } \\
\text { (Partido) }\end{array}$} & Até $\mathbf{1}^{\mathbf{0}}$ Grau & $\mathbf{2}^{\mathbf{0}}$ Grau & Superior \\
\hline Alckmin (PSDB) & $50 \%$ & $48 \%$ & $55 \%$ \\
Mercadante (PT) & $25 \%$ & $28 \%$ & $23 \%$ \\
$\begin{array}{l}\text { Russomano } \\
\text { (PDS/PP) }\end{array}$ & $09 \%$ & $09 \%$ & $06 \%$ \\
\hline
\end{tabular}

Fonte: Datafolha. Idem.

Como se vê, a votação no candidato tucano cresce na medida em que aumentam a escolaridade e a renda das amostras. Por outro lado, a preferência no candidato petista oscila positivamente na medida em que evoluem a escolaridade e a renda dos entrevistados, porém com uma queda abrupta entre os eleitores mais abastados e de nível superior. Por fim, vale citar que, a despeito de sua performance pouco significativa na soma geral dos votos, o candidato do PDS/PP foi mais apoiado entre os eleitores de estratos inferiores de escolaridade e renda. 


\section{Eleições 2014 - Realinhamento às Avessas}

Se em 2010 apontava-se para uma tendência de reconfiguração das bases eleitorais dos partidos no Estado de São Paulo em termos semelhantes ao panorama nacional, este cenário sofreu inflexão importante na eleição para governador seguinte. Com efeito, a reeleição de Geraldo Alckmin com larga margem sobre seus principais adversários não apenas garantiu o sexto mandato paulista consecutivo ao PSDB, mas também alijou o PT da segunda colocação que conquistara nos últimos três pleitos.

O gráfico de votação dos principais competidores em relação ao índice de escolaridade média das zonas e municípios aponta para uma configuração diversa em termos de distribuição de eleitores em relação a 2010:

\section{Gráfico 7 Percentual Médio de Votos Válidos por Decil de Escolaridade das Zonas Eleitorais - $1^{\circ}$ Turno - 2014}

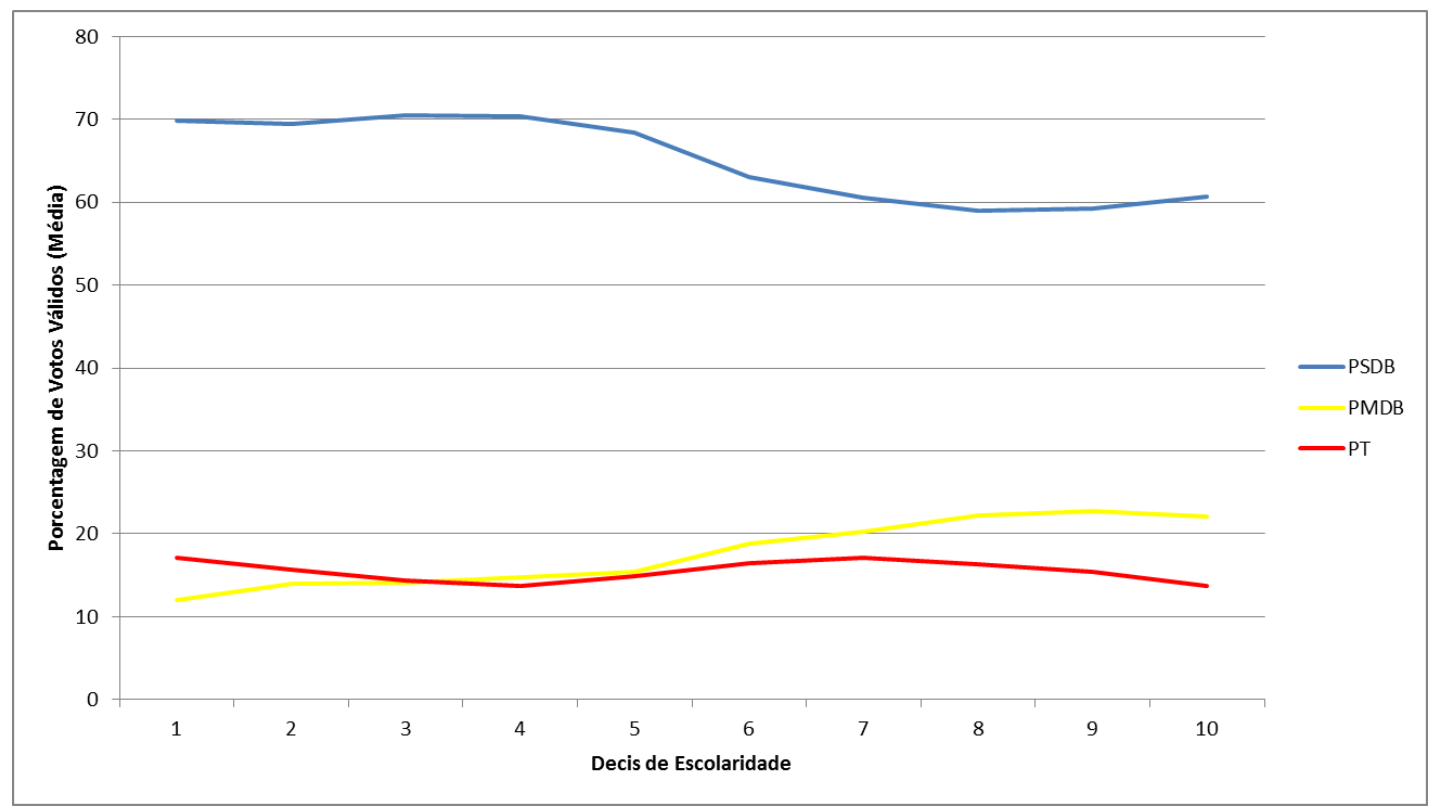

Fonte: TSE

Como se vê, o apoio ao candidato tucano é expressivo em todas as faixas do eleitorado - convém frisar que Alckmin conseguiu sua reeleição com quase $60 \%$ dos votos totais. Interessante notar, porém, que o governador atingiu seus maiores percentuais de votação entre os eleitores de localidades com menor escolaridade média. Alckmin também atingiu níveis elevados de votação entre os eleitores do último decil, mas sua performance foi ainda mais significativa nos estratos mais baixos - em termos de escolaridade - do eleitorado. 
Já o candidato petista, que no último pleito apontava para bases de votação inversamente relacionadas para o nível de escolaridade do eleitorado, neste pleito teve um perfil relativamente homogêneo entre os diferentes decis de escolaridade.

O segundo colocado, Paulo Skaf, trouxe novamente o PMDB para o cenário de disputa eleitoral para o governo do Estado (em 2010, o partido apoiara Alckmin) e com novidades em termos das bases sociais do partido: de forma contrária ao perfil histórico do PMDB nas eleições anteriores (1990 a 2006), em 2014 os votos no partido aumentaram à medida em que avançava o nível médio de escolaridade dos eleitores. Tem-se, assim, um PMDB de característica menos "popular". A sigla oriunda do velho MDB passa a emular, pela primeira vez, o perfil de votação da antiga rival ARENA (LAMOUNIER, op. cit.).

As pesquisas eleitorais estratificadas apontam para tendência semelhante:

Quadro 24- Preferência dos Eleitores por Renda Familiar Mensal - Eleições para Governador (2014) - $1^{\circ}$ Turno

\begin{tabular}{lcccc}
\hline $\begin{array}{c}\text { Candidato } \\
\text { (Partido) }\end{array}$ & $\begin{array}{c}\text { Até 2 Salários } \\
\text { Mínimos }\end{array}$ & $\begin{array}{c}\text { 2 a 5 Salários } \\
\text { Mínimos }\end{array}$ & $\begin{array}{c}\text { 5 a 10 Salários } \\
\text { Mínimos }\end{array}$ & $\begin{array}{c}>\text { 10 Salários } \\
\text { Mínimos }\end{array}$ \\
\hline $\begin{array}{l}\text { Alckmin } \\
\text { (PSDB) }\end{array}$ & $54 \%$ & $49 \%$ & $48 \%$ & $47 \%$ \\
Skaf (PMDB) & $13 \%$ & $23 \%$ & $28 \%$ & $36 \%$ \\
Padilha (PT) & $11 \%$ & $11 \%$ & $09 \%$ & $09 \%$ \\
\hline
\end{tabular}

Fonte: Datafolha. Pesquisa com amostra estadual (SP) de 3112 eleitores, realizada entre 01 e 02 de Outubro de 2014. Margem de erro de 2 p.p. e intervalo de confiança de $95 \%$. 
Quadro 25- Preferência dos Eleitores por Grau de Escolaridade - Eleições para Governador (2014) - $1^{\circ}$ Turno

\begin{tabular}{lccc}
\hline $\begin{array}{c}\text { Candidato } \\
\text { (Partido) }\end{array}$ & Até 1 ${ }^{\mathbf{0}}$ Grau & $\mathbf{2}^{\mathbf{0}}$ Grau & Superior \\
\hline Alckmin (PSDB) & $55 \%$ & $50 \%$ & $44 \%$ \\
Skaf (PMDB) & $14 \%$ & $23 \%$ & $32 \%$ \\
Padilha (PT) & $12 \%$ & $10 \%$ & $09 \%$ \\
\hline
\end{tabular}

Fonte: Datafolha. Idem.

É possível perceber claramente uma distinção de bases sociais das candidaturas e perfil relativamente "homogêneo" de votação no candidato petista. Por um lado, Alckmin obtém seus maiores percentuais de apoio entre os eleitores de menor escolaridade e renda. Skaf, por sua vez, obtém índices expressivos entre os entrevistados com ensino superior e renda familiar mensal acima de 10 salários mínimos. Nestes segmentos, o candidato do PMDB chega a atingir um terço das preferências dos eleitores.

Em nível nacional, porém, mantinha-se a dinâmica de distribuição que configurada nos pleitos de 2006 e 2010, conforme demonstram os dados das pesquisas eleitorais nacionais abaixo:

Quadro 26- Preferência dos Eleitores por Renda Familiar Mensal - Eleições para Presidente (2014) $-1^{\circ}$ Turno

\begin{tabular}{lcccc}
\hline $\begin{array}{c}\text { Candidato } \\
\text { (Partido) }\end{array}$ & $\begin{array}{c}\text { Até 2 Salários } \\
\text { Mínimos }\end{array}$ & $\begin{array}{c}\text { 2 a 5 Salários } \\
\text { Mínimos }\end{array}$ & $\begin{array}{c}\text { 5 a 10 Salários } \\
\text { Mínimos }\end{array}$ & $\begin{array}{c}\text { > 10 Salários } \\
\text { Mínimos }\end{array}$ \\
\hline Dilma (PT) & $49 \%$ & $37 \%$ & $28 \%$ & $24 \%$ \\
Aécio (PSDB) & $17 \%$ & $26 \%$ & $33 \%$ & $41 \%$ \\
Marina (PSB) & $20 \%$ & $24 \%$ & $22 \%$ & $25 \%$ \\
\hline $\begin{array}{l}\text { Fonte: Datafolha. Pesquisa com amostra nacional de } 18116 \text { eleitores, realizada entre } 03 \\
\text { e 04 de Outubro de 2014. Margem de erro de 2 p.p. e intervalo de confiança de } 95 \% .\end{array}$
\end{tabular}


Quadro 27- Preferência dos Eleitores por Grau de Escolaridade - Eleições para Presidente (2014) $-1^{\circ}$ Turno

\begin{tabular}{cccc}
\hline $\begin{array}{c}\text { Candidato } \\
\text { (Partido) }\end{array}$ & Fundamental & Médio & Superior \\
\hline Dilma (PT) & $50 \%$ & $38 \%$ & $26 \%$ \\
Aécio (PSDB) & $19 \%$ & $24 \%$ & $34 \%$ \\
Marina (PSB) & $18 \%$ & $24 \%$ & $26 \%$ \\
\hline
\end{tabular}

Fonte: Datafolha. Idem.

\section{Sintese}

Neste capítulo, procuramos verificar a hipótese de que, nas eleições para o executivo paulista, teria ocorrido reconfiguração eleitoral após 2002 de forma análoga à ocorrida em nível federal - a saber, com clivagens socioeconômicas identificáveis entre o voto no PSDB (locais de maior escolaridade e renda) e PT (locais de menor escolaridade e renda). Por possuir maiores níveis de desenvolvimento e um contingente expressivo de sua população com níveis mais elevados de desenvolvimento (conforme demonstramos no início deste capítulo a partir de dados comparados com o conjunto da população brasileira e de outros Estados), São Paulo teria peculiaridades em relação a outros Estados da Federação. Ou seja, os efeitos do realinhamento eleitoral seriam menos perceptíveis em São Paulo por suas próprias características sociodemográficas fator este que poderia apontar evidências para análise da permanência do partido tucano à frente do governo paulista ao longo de seis mandatos.

Para testar esta hipótese, utilizamos dados de votações das eleições para governador por zonas e municípios, comparados com o índice de escolaridade médio dessas localidades. Além disso, utilizamos pesquisas eleitorais estratificadas por escolaridade e renda, de forma a identificar a distribuição de preferência dos eleitores a partir de suas diferenças nesses quesitos.

Nas eleições prévias a 2002, verificamos que o perfil de votação do PSDB era semelhante ao do PT: ambos os partidos possuíam maior apoio na medida em que aumentavam os níveis de escolaridade e renda do eleitorado. A partir da eleição de 1994, porém, o PSDB passa a contar com um significativo apoio entre as classes mais 
populares, retirando do PMDB a primazia da preferência nesta faixa do eleitorado ainda que este último mantivesse, naquele período e em menor quantidade, bases sociais identificáveis entre os eleitores de menor escolaridade e renda. Vale destacar também que o apoio popular a candidaturas à direita manteve-se significativo nos pleitos de 1990, 1994 e 1998 - sendo Maluf (PDS/PP) o principal expoente deste campo em 1990 e 1998 e Francisco Rossi (PDT) em 1994.

Nas eleições de 2002, os dados de pesquisas eleitorais mostram indiferenciação no padrão de preferências no PSDB na medida em que se elevavam o nível de escolaridade e maior apoio ao partido quando avançam os níveis de renda da amostra; porém, os dados referentes ao padrão de votação dos partidos conjugados com escolaridade dos eleitores apontam para um decréscimo de votação no partido na medida em que avança a escolaridade média dos locais. Estamos cientes de que esta discrepância torna difícil situar de maneira precisa as bases sociais do PSDB neste pleito. Vale destacar, porém, que o pleito de 2002 marcou uma importante mudança no cenário político nacional, com a chegada do PT ao poder central pela primeira vez (bem como a primeira transição eleitoral entre situação e oposição desde a redemocratização). No Estado de São Paulo, a passagem do PT ao segundo turno pela primeira vez também não pode ser desprezada. Assim, nossa hipótese interpretativa é de que o pleito de 2002, dadas as profundas modificações apontadas acima, teve padrões de distribuição menos perceptíveis em termos de bases sociais. Nesse sentido, as tendências que se mostrariam mais sólidas ao longo dos próximos pleitos estavam menos claras e não "decantadas" de maneira plena até aquele momento, o que tornou o cenário mais volátil do ponto de vista da análise eleitoral.

Já para as eleições de 2006, os dados de pesquisas eleitorais e a distribuição de votos por municípios e zonas eleitorais conjugadas com escolaridade média mostram um amplo predomínio do PSDB em todas as faixas de escolaridade e renda, bem como um padrão também quase homogêneo de distribuição de preferências no seu principal adversário (o PT) nestas variáveis. É fato que a intenção de voto no PSDB cresce à medida em que aumenta a renda do eleitorado nesta eleição, situação ao encontro do padrão de voto no partido em nível nacional. Digno de nota, porém é o fato de o PSDB possuir metade da preferência dos eleitores nos segmentos de menor renda e escolaridade do eleitorado - padrão em muito diverso do cenário nacional. 
Em 2010, o cenário paulista parecia um pouco mais próximo do cenário nacional. Persistiu o predomínio do PSDB em todas as faixas de escolaridade e renda (nas pesquisas eleitorais e nos resultados eleitorais estratificados pela escolaridade média das zonas e municípios); porém, foi possível identificar de maneira mais clara tendência de inversão no perfil de votação entre PT e PSDB em termos de escolaridade e renda. Pela primeira vez no Estado de São Paulo e com "atraso" de uma eleição, o PT passava a apresentar um padrão mais semelhante ao "lulista" de votação. Em um contexto de altíssima popularidade do presidente Lula (que elegeu sua sucessora e encerrou seu mandato como o presidente mais bem avaliado da história, de acordo com o Datafolha ${ }^{40}$, com $83 \%$ de avaliação ótima ou boa por parte dos eleitores), o partido teve seu melhor desempenho no Estado e conseguiu vencer o PSDB em municípios e regiões de menor desenvolvimento socioeconômico (franjas periféricas da Grande São Paulo e localidades do Vale do Ribeira e do Pontal do Paranapanema). Persistia, ainda assim, apoio considerável ao PSDB nos estratos de menor renda e escolaridade do eleitorado.

Em 2014, o "ensaio" de realinhamento ocorrido em 2010 dissipa-se e uma configuração nova de distribuição de preferências parece se estabelecer. A vitória de Geraldo Alckmin no pleito foi obtida por meio de um amplo apoio entre todos os segmentos do eleitorado. Porém, decrescia o nível de preferência no candidato do PSDB à medida em que aumentavam os níveis de escolaridade e renda do eleitorado. Em um distante segundo lugar, não mais se encontrava o PT (coadjuvante nesta eleição, teve metade dos votos válidos obtidos quatro anos antes), mas sim o PMDB. Seu candidato, Paulo Skaf, em muito diferiu dos candidatos peemedebistas dos anos 1980, 1990 e 2000, que obtinham maior apoio nos segmentos populares do eleitorado. Contrariamente, o padrão de votação no líder patronal - presidente da Federação das Indústrias do Estado de São Paulo (FIESP) - era o inverso daquele obtido pela então "sigla mágica": a preferência por ele aumentava à medida em que aumentavam os índices de escolaridade e renda do eleitorado.

A análise destes resultados nos permite afirmar que a hipótese norteadora deste capítulo mostrou-se válida apenas em termos. Por um lado, foi possível identificar um amplo apoio ao PSDB entre os segmentos de média / alta escolaridade e renda do

\footnotetext{
${ }^{40}$ Pesquisa disponível em: http://datafolha.folha.uol.com.br/opiniaopublica/2010/12/1211078-acima-dasexpectativas-lula-encerra-mandato-com-melhor-avaliacao-da-historia.shtml (acesso em 10/09/2015).
} 
eleitorado (conforme esperado). Não há, porém, diminuição significativa das preferências pelo partido tucano nas eleições estaduais em São Paulo entre os eleitores de menor escolaridade e renda. Inversamente, em 2014 a vitória de Geraldo Alckmin teve colorações "lulistas": seus índices de votação aumentavam em razão inversa ao nível de desenvolvimento socioeconômico do eleitorado.

Neste sentido, é importante frisar este achado: em São Paulo, o realinhamento eleitoral ocorrido em nível nacional teve características diversas. As bases sociais brasileiras características do PSDB mantiveram-se (eleitorado de maior escolaridade e renda). A recíproca ao PT, porém, não foi verdadeira: o partido tucano conseguiu manter um amplo apoio entre os segmentos mais populares do eleitorado. ${ }^{41}$

É importante, para fins de conclusão deste capítulo, retornarmos às premissas que o nortearam. Com efeito, dadas as características socioeconômicas singulares do Estado de São Paulo, não são surpreendentes os elevados índices de votação do PSDB nesta localidade. Ademais, poderia se argumentar que, em termos proporcionais, o quantitativo de eleitores em situações de maior vulnerabilidade social é significativamente menor, o que distorce a capacidade preditiva de análises que enfatizem as desigualdades sociais presentes no eleitorado. Dito de maneira mais simples: por ter menos "pobres”, São Paulo possui característica peculiar frente a outros Estados brasileiros.

Deve-se levar em conta, porém, que não é desprezível o contingente populacional com condições de vulnerabilidade significativa no território paulista. Para além de regiões com histórico de baixos níveis de desenvolvimento (casos do Vale do Ribeira, Pontal do Paranapanema e Sudoeste Paulista), as franjas das metrópoles são regiões de grande vulnerabilidade. De acordo com o Índice Paulista de Responsabilidade Social da Fundação SEADE (SEADE; 2010), 4,5 milhões de pessoas

\footnotetext{
${ }^{41}$ Esta situação já havia sido identificada por Fernando Limongi quando da análise dos resultados das eleições presidenciais de 2014. Em seminário realizado logo após o pleito (disponível em: https://www.youtube.com/watch?v=sBaqimLln90; acesso em 05 de setembro de 2015), o autor apresentou votações dos partidos conjugados com escolaridade média das localidades e mostrou quadro semelhante. Em Minas Gerais, o padrão de votação em "x" de PSDB e PT se dava na conformidade do quadro nacional (predomínio do PT nos locais de menor escolaridade e do PSDB nos de maior). Em São Paulo, porém, as clivagens eram menos perceptíveis: mesmo nas localidades de menor escolaridade, o PSDB conseguiu obter elevados índices de votação, em muitos superiores a localidades de padrão semelhante no resto do Brasil. Destaque-se que no segundo turno do pleito de 2014, Aécio Neves (PSDB) obteve no Estado de São Paulo dois terços dos votos válidos (Fonte: TSE).
} 
no Estado viviam em localidades urbanas de alta vulnerabilidade social, e 1,8 milhões em locais de muito alta vulnerabilidade (aglomerados subnormais urbanos).

Além disso, convém destacar que, ao segmentarmos o eleitorado por condições de escolaridade e renda, desprezamos a magnitude deste contingente em termos populacionais. Ou seja, não se pretende identificar qual a representação de determinado perfil de uma amostra em relação ao conjunto de eleitores, mas sim identificar, no interior deste campo, qual a distribuição de preferências entre os eleitores. Neste sentido, ganham relevância os resultados aqui encontrados, os quais salientamos mais uma vez: no Estado de São Paulo, o PSDB possui índices elevados de apoio entre os segmentos mais populares do eleitorado - em situação oposta à encontrada, ao menos desde 2006, no panorama eleitoral nacional.

Reveste-se de maior complexidade a tarefa de compreender as raízes deste fenômeno. Poderia ser destacada, por exemplo, a influência de determinados padrões sociais de interação predominantes em relação ao conjunto do eleitorado. Em estudo sobre características industriais do $\mathrm{ABC}$ paulista e sua influência sobre o processo eleitoral ao longo do Regime Militar e no início da redemocratização naquela região, Maria Teresa Sadek (1984) argumentou que a crescente presença de um movimento operário atuante e organizado na região (que desembocaria, afinal, no berço do novo sindicalismo brasileiro e na formação do PT) teve papel decisivo no desempenho do MDB (e do PMDB, quando da redemocratização) em toda a região ao longo das eleições ocorridas no Regime Militar (mesmo em locais nos quais o movimento operário era menos presente). Este "transbordamento", segundo a autora, derivaria da grande relevância deste segmento específico para o conjunto da região e de sua capacidade de indução do comportamento político.

De maneira análoga, poderia se argumentar que a prevalência, em São Paulo, de um contingente muito expressivo de eleitores de classe média e alta possui implicações para além de suas próprias fronteiras socioeconômicas. Assim, a capacidade de indução de comportamentos, ideologias e crenças de parcela mais expressiva da população poderia vir a ter efeitos importantes para o conjunto do eleitorado. Afinal, eleições, assim como qualquer processo sociopolítico, ocupam o terreno específico de determinados territórios, e os efeitos geográficos de determinadas características prevalentes não podem ser desconsiderados. Lembremos, por exemplo, do padrão de 
votação das candidaturas do PT nos Estados do Nordeste nas últimas eleições votações essas ancoradas sobremaneira em localidades menos desenvolvidas do eleitorado, mas também muito expressiva em segmentos de maior escolaridade e renda. Trataremos em pormenores destes aspectos no capítulo seguinte.

Vale resgatar, ademais, a contribuição de Lipset (1967) para a compreensão do comportamento eleitoral nas democracias modernas. Segundo o autor,

"embora pareça evidente que a maioria dos fatores estruturais que determinam a escolha partidária (...) possa ser encarada como aspectos de um sistema de estratificação, existem claramente muitas outras variáveis sociais que interatuam com a classe e a política" (LIPSET, 1967, p. 275).

Entre estes fatores, o autor situa o tradicionalismo (valores arraigados de determinados grupos sociais que, mesmo em condições propícias ao voto em partidos à esquerda do espectro ideológico, sufragam partidos conservadores) e as crenças em oportunidades para a mobilidade individual. Neste caso, a escolha por ações coletivas em favor da reforma social - em grau mais ou menos acelerado - é rechaçada em favor de ideologias mais propensas ao individualismo e ao esforço para ascensão dentro de determinada ordem econômica vigente, o que levaria a maior apoio a partidos com orientação liberal (em termos econômicos) ou francamente conservadores mesmo entre os estratos mais populares do eleitorado.

Neste sentido, é importante salientar, por fim, uma característica relevante apontada pela literatura referente aos processos eleitorais em São Paulo. A despeito da ideia intuitiva de que os setores menos favorecidos da população tendem a sufragar candidatos posicionados à esquerda do espectro partidário, a presença do que se convencionou denominar "conservadorismo popular" possui implicações importantes no panorama paulista - com implicações sobre a organização partidária e a capacidade de indução de preferências dos eleitores. Ainda que fuja do recorte desta pesquisa, abordaremos brevemente o tema no capítulo conclusivo dessa dissertação. 


\section{Capítulo 3 - Dinâmica Eleitoral no Território Paulista: Municípios e Variações Regionais}

No capítulo anterior, procuramos identificar as bases de apoio aos partidos a partir da análise de seus padrões de votação conjugados com características socioeconômicas do eleitorado. Trabalhamos com dados amostrais representativos do conjunto do eleitorado paulista, estratificados por escolaridade e renda, além de índices de votação conjugados com escolaridade média dos territórios eleitorais (proxy para análise do nível de desenvolvimento das localidades analisadas).

Verificamos que, a partir de 2002, o apoio ao PSDB é crescente à medida em que se elevam as condições socioeconômicas dos eleitores. Ocorre que, mesmo entre os estratos mais populares do eleitorado, o PSDB possui um expressivo suporte eleitoral. $\mathrm{O}$ PT obtém maior apoio nestes setores do eleitorado, mas ainda assim fica distante de seu principal adversário. Neste sentido, não se verificou nas eleições para o governo do Estado de São Paulo após 2002 uma inversão de bases eleitorais dos principais partidos aos moldes do padrão nacional. Ademais, as eleições de 2014 apontam para panorama distinto de bases sociais dos principais partidos, uma vez que a candidatura tucana obteve suporte maior entre os estratos de menor escolaridade e renda da população.

É importante salientar novamente, porém, que o território paulista não é homogêneo em sua extensão. Salientamos dois aspectos: a magnitude dos municípios em termos populacionais e a distinção entre áreas densamente urbanizadas como a metrópole paulistana (ou seja, a capital e seu entorno) e outras regiões do Estado.

No primeiro capítulo, levantamos contribuições da literatura que apontaram a presença de padrões diferenciados de distribuição de preferências entre os principais partidos no Estado de São Paulo em termos regionais. Ainda nos anos 1960, Francisco Weffort (1965) e Oliveiros Ferreira (1964) utilizaram variáveis de caráter regional e de magnitude populacional para a compreensão dos resultados das eleições estaduais paulistas no Regime de 1946.

Em análise sobre a eleição estadual de 1962, Weffort (op.cit., p. 50) apontou a prevalência de Jânio Quadros sobre Adhemar de Barros nas cidades mais urbanizadas do Estado. Segundo o autor, tal situação era reveladora da presença de conteúdos sociais e políticos diferentes associados às figuras de cada líder - sendo Jânio Quadros o representante dos setores operários urbanos em ascensão (em função da industrialização 
acelerada que ocorria no Estado à época) e que buscariam, ainda que de maneira difusa, um líder reformador e progressista. Adhemar de Barros, por sua vez, teria atraídos os setores vinculados ao mundo rural (pequenos proprietários) e o "lúmpen" (marginalizados do processo de inclusão industrial) que, à época, estagnavam ou regrediam frente ao dinamismo socioeconômico das regiões densamente urbanizadas. Seria, assim, a liderança cuja imagem evocava o líder patriarcal capaz de restaurar o passado estável de outrora.

Ferreira (1965), ao analisar o mesmo pleito e traçar um histórico dos dois pleitos anteriores (1954 e 1958), divide o Estado em duas unidades de análise: a área P (capital e seu entorno, formada pelas cidades mais densamente industrializadas e urbanizadas do Estado) e R (formada pelo restante dos municípios paulistas). O autor também demonstra a prevalência de Jânio Quadros nas áreas mais urbanizadas (P) e Adhemar de Barros na área restante (R). Interpreta os resultados, porém, de maneira distinta de Weffort (op. cit.). Segundo o autor, desde 1954 é crescente a votação de candidatos alinhados ao perfil reformista e "racional-legal" associados a Jânio Quadros - ascensão esta vinculada à própria industrialização e urbanização do Estado. A vitória de Adhemar em 1962 teria se dado, na interpretação do autor, pela mudança no perfil do candidato, que precisou "compor" uma imagem de administrador capaz e vinculado às ideias modernizadoras vinculadas a Jânio.

Já nos anos 1970, Vilmar Faria (1978) mostrou distinções entre as votações de ARENA e MDB em termos análogos. O partido de suporte ao Regime Militar obtinha suas performances mais expressivas nas cidades menores e menos industrializadas, sendo inverso o perfil de votação de seu adversário (o MDB obtinha melhores resultados nas regiões mais densamente povoadas e com maior participação industrial na economia).

Na virada para o regime democrático, Sadek (1987) mostrou a reversão deste perfil em relação ao sucessor do MDB. Após assumir o governo do Estado em 1982, o PMDB passa a contar na eleição seguinte com maior suporte entre os eleitores das cidades menos urbanizadas e localizadas no interior do Estado. No período recente, Meneghello \& Bizarro (2012) apontaram a continuidade de clivagens regionais importantes entre os partidos no Estado de São Paulo, com presença mais marcante de 
partidos conservadores (PDS/PP, PFL/DEM e PTB) e voto governista (PSDB) nas regiões menos populosas e com menor presença da indústria na economia.

Assim, neste capítulo procuraremos analisar os resultados e conclusões extraídos do capítulo anterior - a saber, a prevalência do PSDB entre as diferentes classes socioeconômicas do Estado, com crescimento nos estratos superiores em nível de desenvolvimento - em termos de sua relação com os territórios, em consonância com a ampla literatura de estudos eleitorais no Estado de São Paulo que demonstra a presença de diferenças regionais expressivas de votação nos principais partidos.

O capítulo está estruturado em três partes. Na primeira, analisaremos a relação entre a votação dos partidos e a magnitude populacional dos municípios. Em seguida, a partir da distinção entre a Região Metropolitana da Grande São Paulo o conjunto de territórios localizados no restante do Estado (ao qual denominaremos de "interior"), procuraremos verificar se as bases de apoio dos principais partidos se alteram quando analisados conjuntamente os recortes acima com nível de desenvolvimento das localidades. Por fim, o intuito é sintetizar os resultados encontrados de forma conjugada com as hipóteses e achados do capítulo anterior.

Tais aspectos (a saber, tamanho de município e localização geográfica dos mesmos - próximos ou longe da capital ou polos regionais, por exemplo) são elementos de diferenciação importantes utilizados na literatura ${ }^{42}$. Testaremos, assim, se tais variáveis se constituem como elementos significativos de diferenciação dos partidos e de suas bases sociais no Estado de São Paulo.

Nossa hipótese é de que o PSDB obtém suporte mais expressivo nas pequenas cidades e no interior do Estado, perfil em consonância com o processo de interiorização atribuído, por Sadek (1987), ao PMDB (partido de origem do PSDB) nos anos 1980. Em relação à distinção Grande São Paulo-interior, verificaremos se o desempenho dos partidos em localidades estratificadas por nível de desenvolvimento médio possui variações nestas duas unidades de análise selecionadas - o que permitirá mensurar de maneira mais precisa (em termos regionais) as clivagens socioeconômicas apontadas no capítulo anterior.

\footnotetext{
${ }^{42}$ Ver, a esse respeito, NICOLAU \& PEIXOTO (2007), ZUCCO (2008) E MENEGHELlO \&
} BIZARRO (2012). 


\section{Voto e Tamanho dos Municípios}

Conforme mencionamos acima, a diversidade socioeconômica e demográfica do Estado de São Paulo deve ser considerada quando analisamos o perfil de votação dos principais partidos. Afinal, não é desprezível o fato de que o Estado conta com as duas cidades brasileiras "campeãs" em termos populacionais extremos: São Paulo (com mais de 11,5 milhões de habitantes) e Borá (com meros 808 munícipes $^{43}$ ).

No quadro 27, apresentamos a divisão dos municípios paulistas de acordo com o tamanho populacional dos mesmos. Vê-se que mais de $60 \%$ dos municípios paulistas contam com menos de 20 mil habitantes. Ao mesmo tempo, 75 municípios paulistas contam com mais de 100 mil moradores.

43 Os dados populacionais deste capítulo foram obtidos junto à Fundação SEADE - Portal IMP (http://www.imp.seade.gov.br; acesso em 17/09/2014). 


\section{Quadro 28- População dos Municípios Paulistas (2014)}

\begin{tabular}{|c|c|c|c|c|c|}
\hline \multirow{2}{*}{ População } & \multirow{2}{*}{$\begin{array}{l}\text { Número de } \\
\text { Municípios }\end{array}$} & \multicolumn{2}{|c|}{ População } & \multicolumn{2}{|c|}{ Acumulado } \\
\hline & & Milhões & $\%$ & Milhões & $\%$ \\
\hline $\begin{array}{l}\text { Até } 10 \text { mil } \\
\text { habitantes }\end{array}$ & 276 & 1,374 & 3,2 & 1,374 & 3,2 \\
\hline $\begin{array}{l}\text { De } 10 \text { a } 20 \text { mil } \\
\text { habitantes }\end{array}$ & 121 & 1,745 & 4,1 & 3,119 & 7,3 \\
\hline $\begin{array}{c}\text { De } 20 \text { a } 50 \text { mil } \\
\text { habitantes }\end{array}$ & 118 & 3,830 & 8,9 & 6,950 & 16,2 \\
\hline $\begin{array}{c}\text { De } 50 \text { a } 100 \text { mil } \\
\text { habitantes }\end{array}$ & 55 & 3,834 & 9,0 & 10,784 & 25,2 \\
\hline $\begin{array}{l}\text { De } 100 \text { a } 500 \text { mil } \\
\text { habitantes }\end{array}$ & 66 & 13,917 & 32,6 & 24,701 & 57,9 \\
\hline $\begin{array}{l}\text { Acima de } 500 \text { mil } \\
\text { habitantes }\end{array}$ & 9 & 17,971 & 42,1 & 42,673 & 100 \\
\hline TOTAL & 645 & 42,673 & $100 \%$ & 42,673 & $100 \%$ \\
\hline
\end{tabular}

Fonte: Fundação SEADE

Nesta seção, vamos verificar a performance dos principais partidos competidores em relação ao tamanho dos municípios desde 1994. O intuito é verificar se há, dentre os partidos, diferenças importantes de sufrágio quando considerada a dimensão populacional das cidades. Os eventuais achados poderão matizar e situar de maneira mais precisa a presença das forças políticas predominantes no território paulista, para além dos aspectos socioeconômicos gerais apontados no capítulo anterior.

Primeiramente, por meio da mesma classificação populacional utilizada acima, vamos verificar a performance dos principais partidos em cada grupo de municípios conforme o número de habitantes. 
Quadro 29 - Percentual de Votos Válidos por Grupo de Municípios (1994-2014) - PSDB - $1^{\circ}$ Turno

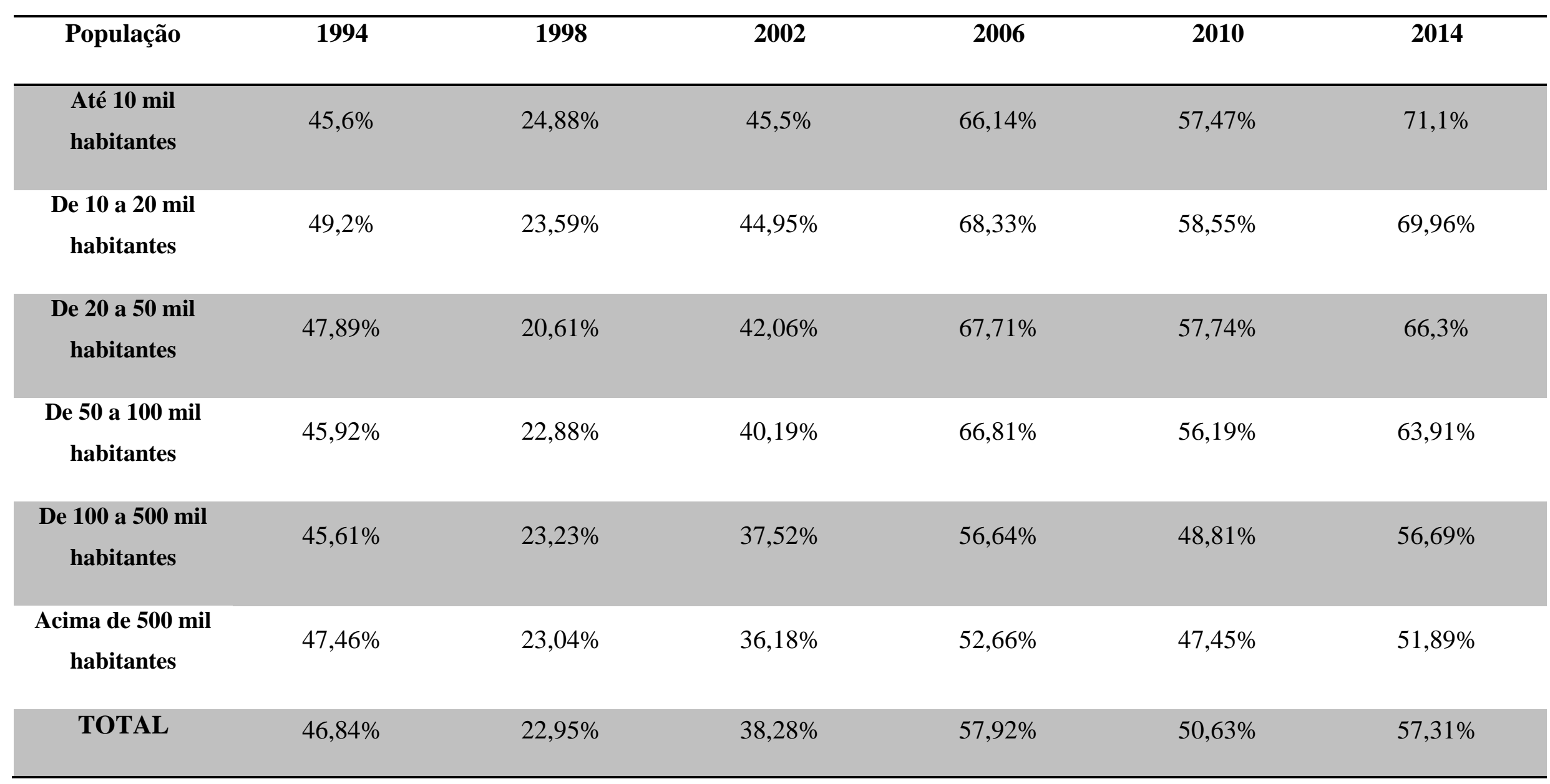

Fonte: TSE; Fundação SEADE 
Quadro 30 - Percentual de Votos Válidos por Grupo de Municípios (1994-2014) - PT - 1 $^{\text {Turno }}$

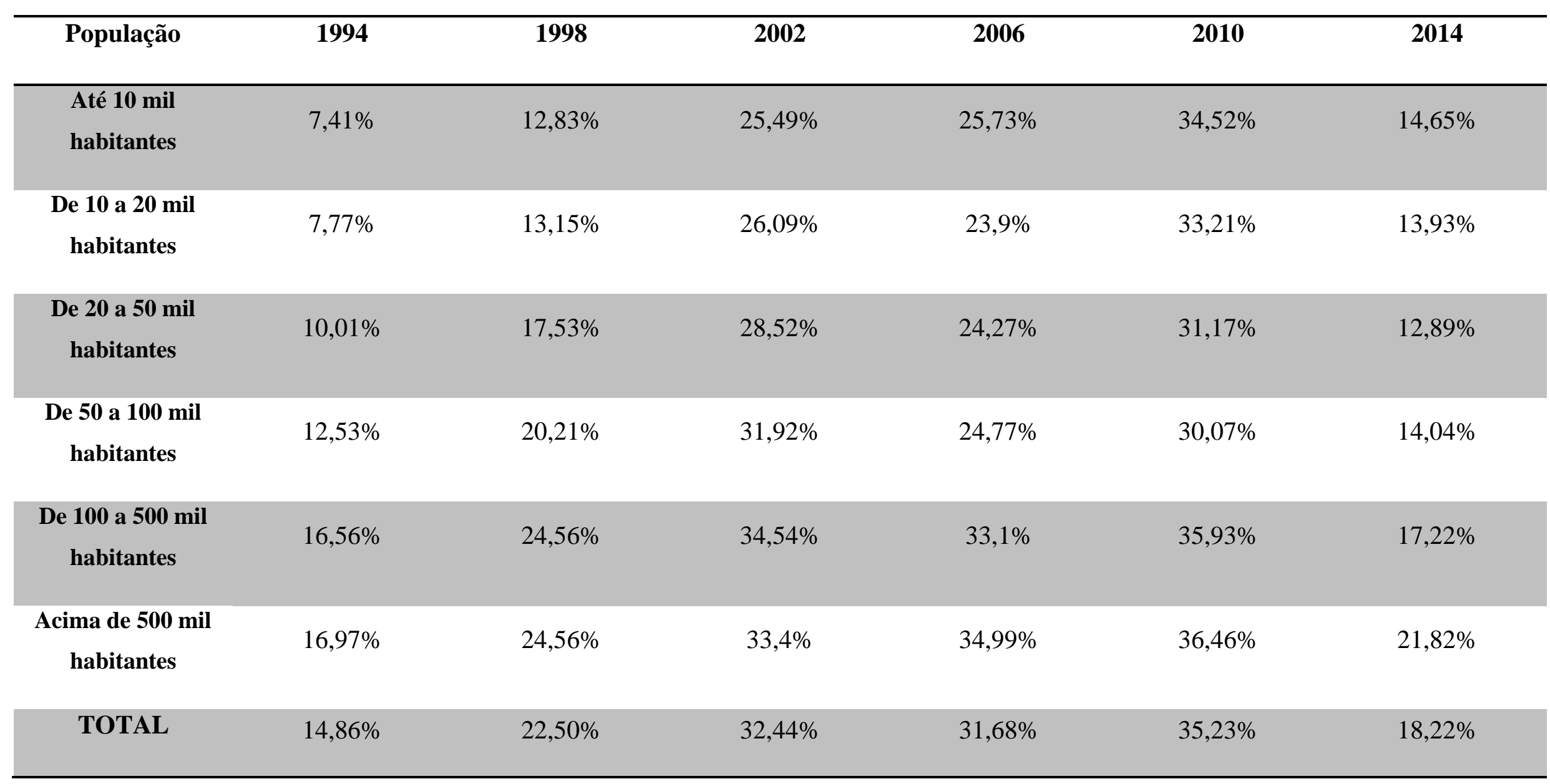

Fonte: TSE; Fundação SEADE 
Quadro 31 - Percentual de Votos Válidos por Grupo de Municípios (1994-2014) - PMDB - $1^{\circ}$ Turno

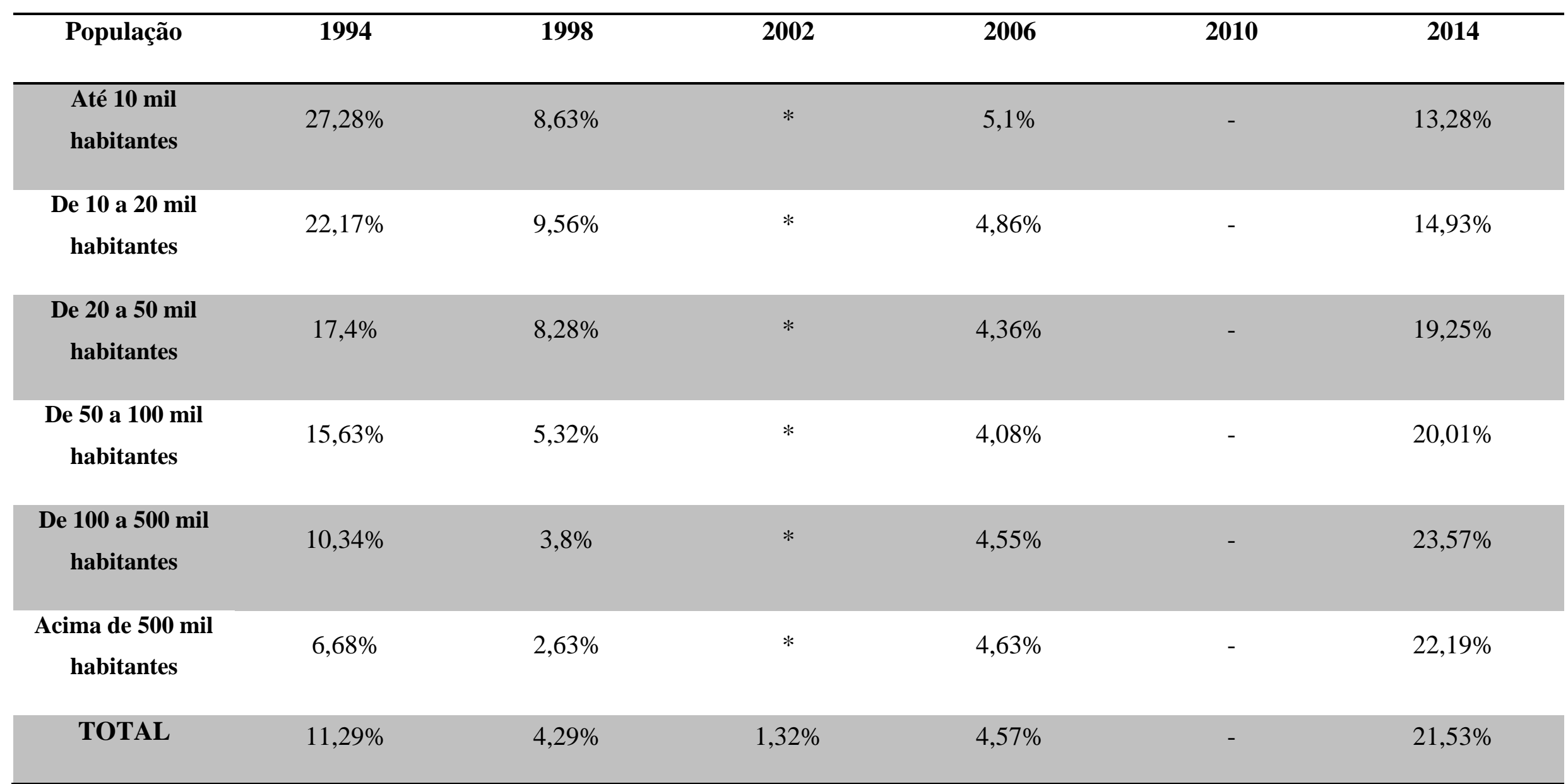

(*) Nesta eleição, o candidato peemedebista foi substituído no meio da disputa - Fernando Morais deu lugar a Lamartine Posella - e obteve apenas $1,32 \%$ dos votos válidos - razão pela qual não efetuamos a distribuição acima. Fonte: TSE; Fundação SEADE 
Quadro 32 - Percentual de Votos Válidos por Grupo de Municípios (1994-2014) - PDS/PP - $1^{\circ}$ Turno

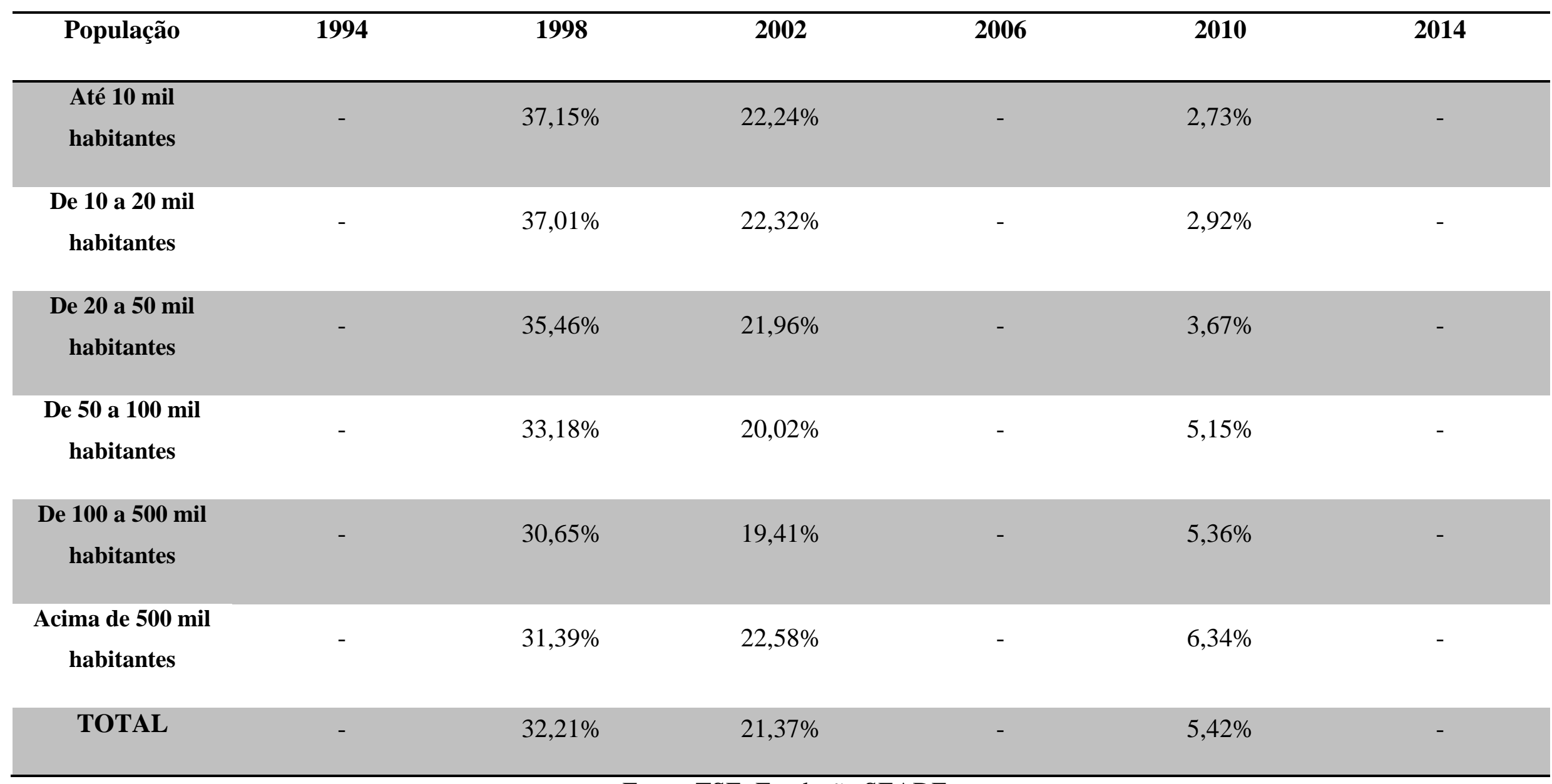

Fonte: TSE; Fundação SEADE 
Quadro 33 - Percentual de Votos Válidos por Grupo de Municípios (1994-2014) - PDT - $1^{\circ}$ Turno

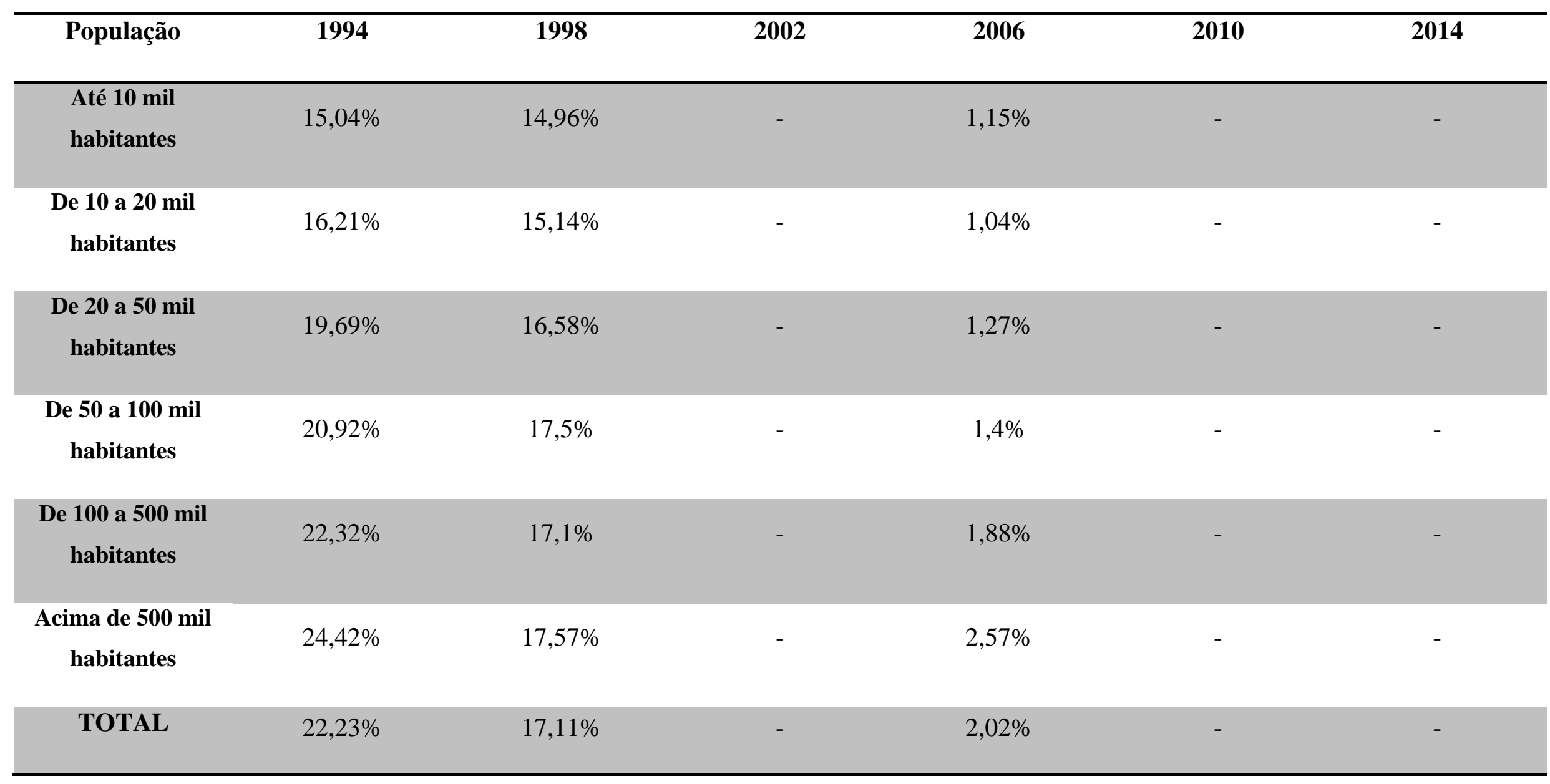

Fonte: TSE; Fundação SEADE 
Efetuamos também testes de correlação ( $\mathrm{R}$ de Pearson) entre o percentual de votos válidos dos principais partidos em cada cidade em relação ao contingente populacional dos municípios. Mais uma vez, utilizamos dados eleitorais do TSE conjugados com informações demográficas da Fundação SEADE.

Nas palavras de Figueiredo Filho e Silva Jr. (2009), “(...) o coeficiente de correlação de Pearson (r) é uma medida de associação linear entre variáveis". Varia de 1 a 1, casos extremos em que a modificação no escore de uma variável está direta (positivo) ou inversamente (negativo) proporcional à outra. De maneira oposta, um coeficiente de correlação igual ou próximo a zero indica que não há relação linear alguma entre as variáveis, sendo completamente aleatório o padrão de interação entre as mesmas.

Importante frisar também que o coeficiente de correlação é uma medida estatística de relação, incapaz de induzir, por si só, qualquer inferência de causalidade. Tanto a interpretação quanto o próprio manuseio dos dados dependem das perspectivas teóricas e metodológicas da pesquisa. Em nosso caso e conforme já citado, diferentes trabalhos apontam para a existência de relação entre suporte eleitoral a um partido e magnitude do município (sendo a primeira variável dependente da segunda). $\mathrm{O}$ índice de correlação, porém, não distingue a ordem das variáveis, o que permitiria, sem o devido cuidado, a absurda inferência inversa: o tamanho do município depende da votação dada a determinados partidos.

Por se tratar de um índice, é importante definir de antemão como classificar a amplitude do coeficiente. Figueiredo Filho e Silva Jr. (op. cit.; p. 5) apontam as seguintes definições:

“(...) Cohen (1998) apresenta a seguinte classificação no que diz respeito à magnitude do coeficiente: $0,10<\mathrm{r}<0,29=$ pequeno; $0,30<\mathrm{r}<0,49=$ médio e $r>0,50=$ grande. Para Dancey e Reidy (2006) valores até 0,30 devem ser considerados fracos, entre 0,40 e 0,60 moderados e acima de 0,70 fortes."

Adotaremos, assim, uma escala semelhante à de Cohen (apud FIGUEIREDO FILHO \& SILVA JR.; 2009) de majoração para interpretação dos coeficientes. Outro aspecto relevante é a presença de outliers, ou seja, dados que apresentam valores em muito superiores ou inferiores à média do conjunto e que, portanto, distorcem a 
capacidade preditiva das correlações encontradas (op. cit., p. 14). No caso da distribuição da população paulista, conforme podemos observar pelo gráfico a seguir, um outlier típico é a cidade de São Paulo.

Gráfico 8 - População dos Municípios Paulistas (2014)

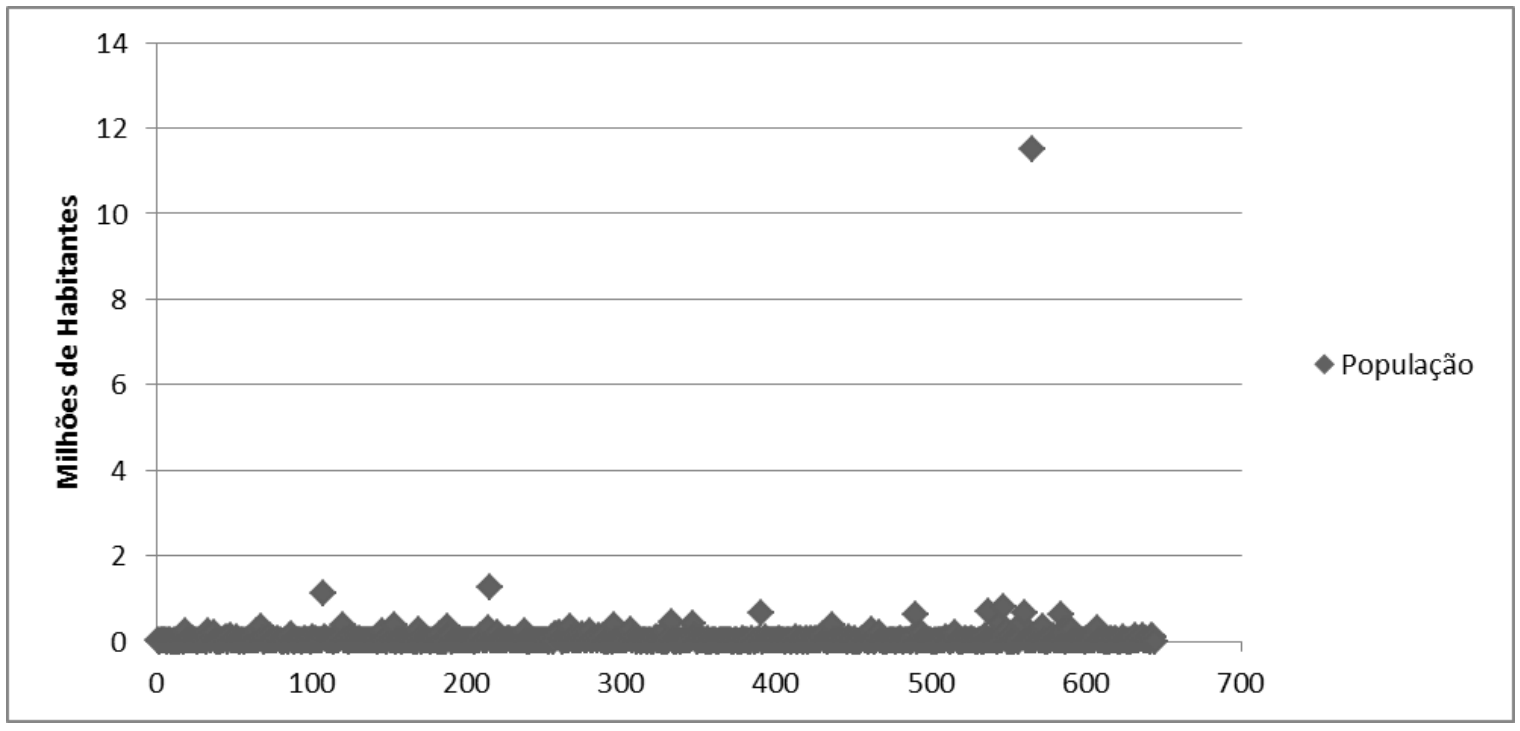

Fonte: Fundação SEADE

O ponto no quadrante superior direito do gráfico refere-se à capital paulista. É visível que a população da capital (que corresponde a um quarto do contingente populacional do Estado) diverge do conjunto de municípios. Sendo assim e de forma a preservar os coeficientes de possíveis distorções, excluímos a cidade de São Paulo dos testes efetuados. Importante mencionar também que os testes nada dizem sobre a performance global dos partidos. Hipoteticamente, um partido que obtém $80 \%$ dos votos igualitariamente em todos os municípios (independentemente do tamanho da população) terá um coeficiente de correlação igual a zero (o que mostra que seu voto não possui bases eleitorais associadas ao tamanho do município). Por outro lado, um pequeno partido, de votações globais na casa de $2 \%$, pode ter este percentual basicamente ancorado nos grandes municípios - seu coeficiente de correlação, assim, será próximo de 1 (o que apontaria para sua "dependência” em relação às regiões mais densamente povoadas).

Feitas essas considerações iniciais, apresentamos no quadro a seguir os testes de correlação entre votação percentual dos principais partidos e o tamanho dos municípios (em parênteses, o grau de significância estatística). As lacunas representam eleições em 
que os partidos analisados não apresentaram candidatos, seja por alienação da disputa, seja por encontrarem-se coligados com outras agremiações que detinham a cabeça de chapa.

Quadro 34 - Correlações ( $R$ de Pearson) entre percentual de votos válidos e população dos municípios paulistas - Eleições para governador ( $1^{\circ}$ Turno)

\begin{tabular}{|c|c|c|c|c|c|c|}
\hline PARTIDO & 1994 & 1998 & 2002 & 2006 & 2010 & 2014 \\
\hline \multirow{3}{*}{ PSDB } & $-0,078$ & $-0,108$ & $-0,264$ & $-0,326$ & $-0,306$ & $-0,432$ \\
\hline & $(0,05)$ & $(0,0)$ & $(0,0)$ & $(0,0)$ & $(0,0)$ & $(0,0)$ \\
\hline & $*$ & $* * *$ & $*$ & $* * *$ & $* * *$ & $* * *$ \\
\hline \multirow{3}{*}{ PT } & 0,534 & 0,518 & 0,364 & 0,279 & 0,070 & 0,171 \\
\hline & $(0,0)$ & $(0,0)$ & $(0,0)$ & $(0,0)$ & $(0,07)$ & $(0,0)$ \\
\hline & $* * *$ & $* * *$ & $* * *$ & $* * *$ & $*$ & $* * *$ \\
\hline \multirow{3}{*}{ PMDB } & $-0,355$ & $-0,176$ & \multirow{3}{*}{\multicolumn{2}{|c|}{$\begin{array}{r}-0,034 \\
(0,38)\end{array}$}} & \multirow{3}{*}{ - } & 0,375 \\
\hline & $(0,0)$ & $(0,0)$ & & & & $(0,0)$ \\
\hline & $* * *$ & $* * *$ & & & & $* * *$ \\
\hline \multirow{3}{*}{ PDS/PP } & & $-0,195$ & $-0,124$ & & 0,401 & \multirow{3}{*}{-} \\
\hline & - & $(0,0)$ & $(0,0)$ & - & $(0,0)$ & \\
\hline & & $* * *$ & $* * *$ & & $* * *$ & \\
\hline \multirow{3}{*}{ PDT } & 0,296 & 0,158 & & 0,448 & \multirow{3}{*}{ - } & \multirow{3}{*}{-} \\
\hline & $(0,0)$ & $(0,0)$ & & $(0,0)$ & & \\
\hline & $* * *$ & $* * *$ & & $* * *$ & & \\
\hline
\end{tabular}

Sem a capital; * $\mathrm{p}<0,1 ; * * \mathrm{p}<0,05 ; * * * \mathrm{p}<0,01$

(a) Nesta eleição, o candidato peemedebista foi substituído no meio da disputa Fernando Morais deu lugar a Lamartine Posella - e obteve apenas 1,32\% dos votos válidos - razão pela qual não foi inserido no quadro acima.

Fonte: Fundação SEADE; TSE

Iniciemos pelo final. Ainda que tenha sido figurante nas disputas eleitorais paulistas após 2000, o PDT teve papel importante nos pleitos dos anos 1990, quando 
uma importante liderança do partido à época, Francisco Rossi, logrou chegar ao segundo turno em 1994 e teve percentual expressivo de votos no pleito seguinte (ocupando a quarta colocação, com mais de $17 \%$ dos votos válidos, nas eleições de 1998). A votação do ex-prefeito de Osasco (Grande São Paulo) é leve e positivamente correlacionada com o tamanho do município, perfil esse ao encontro do próprio perfil do candidato (liderança carismática e popular na região metropolitana da Capital, sobretudo nos municípios densamente povoados da região Oeste - Osasco, Carapicuíba, Itapevi, entre outros). Nos pleitos seguintes, o PDT passaria a figurante das disputas eleitorais, tendo seu candidato em 2006 (o ex-deputado estadual e ex-vereador Carlos Apolinário) obtidos meros $2 \%$ de votos válidos. Como se vê, o índice de correlação torna-se ainda maior, mostrando maior dependência do partido em relação aos grandes municípios. Interpretamos este dado como consequência da dificuldade de pequenos partidos penetrarem em todo o território, razão pela qual concentram suas campanhas nas regiões mais densamente povoadas (algo como o "custo-benefício" da disputa pelo voto).

Outro partido outrora relevante a atualmente pouco expressivo, o PDS/PP acompanhou a decadência eleitoral de sua principal liderança, Paulo Maluf. Observa-se que, nas duas eleições em que foi candidato, Maluf teve uma pequena correlação negativa entre seu nível de votos e o tamanho dos municípios. A pequena magnitude do coeficiente mostra que Maluf possuía penetração ao longo de todo o território, não havendo relação entre o tamanho do município e a performance do candidato. O retorno do PDS/PP em 2010, porém, ocorre em situação distinta. A candidatura de Celso Russomano é mais dependente da votação nos grandes municípios - sinal tanto do recuo do PDS/PP em termos de penetração partidária quanto do perfil do candidato, deputado federal com base na região metropolitana da Capital.

O PMDB, por sua vez, possui um movimento interessante. No início e em consonância com o padrão descrito por Sadek (op. cit.) nos anos 1980, há uma relação linear moderada negativa entre o voto no partido e o tamanho do município - ou seja, a votação do partido era maior nos pequenos municípios. Tal relação torna-se aleatória nos pleitos seguintes até a eleição de 2014, quando inverte-se o perfil de vinte anos antes: neste pleito, passa a haver uma correlação moderadamente positiva entre o voto no partido e o tamanho dos municípios - ou seja, suporte maior nas cidades mais 
povoadas. Tal fato vai ao encontro da hipótese apresentada inicialmente - a saber, a "troca" de predominância no interior entre PSDB e PMDB ${ }^{44}$.

A trajetória do PT é, em certo sentido, oposta. Se nos anos 1990 o partido era fortemente dependente dos grandes municípios (haja vista os níveis de correlação elevados encontrados para os pleitos dessa década), aos poucos o partido torna-se menos "urbano". Em 2006, persistia a correlação positiva (ainda que pequena) entre a votação do partido e o tamanho do município, relação essa que dissipou-se no pleito seguinte. Em certo sentido, poder-se-ia dizer que o PT, ainda que não tenha logrado êxito nas eleições gerais, ao menos suplantou o desafio de maior penetração ao longo do território. A aparente mudança de trajetória no pleito de 2014 (quando o partido volta a apresentar performance com pequena correlação positiva vis-à-vis o tamanho das cidades) parece apontar, preliminarmente, para reversão dessa tendência.

Por fim, o partido objeto dessa pesquisa. É possível identificar claramente uma tendência de aumento da relação negativa entre o tamanho do município e o voto no PSDB - ou seja, aumento do apoio ao partido à medida em que diminui o tamanho dos municípios. Se no pleito de 1994 (e até mesmo em 1998) o voto no partido não possuía relação alguma com a magnitude populacional dos municípios, ao longo das eleições seguintes o perfil de votação do partido tucano torna-se mais expressivo em relação aos pequenos municípios. Ainda que as correlações sejam medianas, apontam para um importante suporte ao partido em relação às pequenas cidades do Estado. Neste sentido, poderia se dizer que, de forma análoga à sua agremiação de origem, o PSDB foi exitoso em seu processo de "interiorização": os dados aqui encontrados mostram um elevado nível de penetração do partido ao longo de todo o território, com prevalência muito grande nos municípios pequenos e médios do Estado. Em 2014, 7 em cada 10 votos válidos dados nos municípios com menos de 10 mil habitantes foi dado ao candidato do PSDB, conforme podemos observar no quadro 28 acima.

É fundamental notar, uma vez mais, que este considerável suporte não se deu em detrimento do apoio ao partido nas regiões mais densamente povoadas. É possível observar, novamente vide o quadro 28 acima, que nos três últimos pleitos (2014, 2010 e

\footnotetext{
${ }^{44}$ Importante lembrar também que, em 2010, com o falecimento de Orestes Quércia, o PMDB perde sua principal liderança política e passa por profunda reestruturação. Este processo é descrito em detalhes por Bizarro Neto (2013). Sobre a organização do PMDB sob Orestes Quércia nos anos 1970 e 1980, ver MELHEM (1998). Não temos elementos suficientes para avançar nesta hipótese, mas há fortes indícios de que o PMDB paulista do pleito de 2014 possui padrões de organização partidária e eleitoral distintos.
} 
2006) o PSDB obteve a maioria absoluta (ou esteve muito próximo de tanto) nas cidades com mais de 100 mil habitantes do Estado. É essa razão, inclusive, pela qual os coeficientes de correlação encontrados foram medianos. Tal fato deve-se pela razão de que o partido tucano obteve performance excepcional nas menores cidades do Estado, mas também muito expressiva (ainda que menor) nos municípios paulista densamente povoados. Ou seja, encontramos índices de correlação medianos entre o voto no PSDB e o tamanho do município porque o desempenho eleitoral do partido nas pequenas cidades foi acompanhado de uma performance também elevada - ainda que um pouco menor - nas maiores cidades do Estado de São Paulo.

\section{Grande São Paulo e Interior - Voto e Desenvolvimento Local}

No capítulo anterior, observamos que o movimento de realinhamento eleitoral ocorrido em nível nacional a partir de 2006 (em que PSDB e PT passam a contar com bases sociais claramente identificáveis e opostas em termos de bases sociais eleitorais) teve características distintas nas eleições estaduais paulistas. Com efeito, em São Paulo o PSDB obtém apoio maior e crescente à medida em que se elevam os níveis de escolaridade e renda do eleitorado. Manteve, porém, suporte expressivo entre os estratos mais populares do eleitorado.

Frisamos, porém, que tais resultados foram encontrados em relação ao eleitorado total do Estado. Haveria, todavia, algum matiz territorial específico neste cenário? Ou seja, seria este resultado um retrato mediano da situação geral no Estado, que ocultaria possíveis cenários diversos à medida em que se adotassem recortes analíticos - em termos de localidades - diferentes?

A diferenciação regional foi baliza para a produção da literatura referente aos estudos eleitorais no Estado de São Paulo ao longo do tempo, conforme vimos anteriormente. Com efeito, a interação entre a região metropolitana da capital e o interior (ou, em épocas mais afastadas no tempo, a região "urbanizada" ou "industrializada" e o meio "rural") marca os diferentes trabalhos referentes ao Estado de São Paulo. Desde Ferreira (1964) até Sadek (1987), é comum identificarmos uma chave 
analítica que procura situar a "questão paulista" em termos da dicotomia capital e seu entorno versus interior ${ }^{45}$.

No período mais recente, conforme já observado, Sadek (op.cit.) identificou uma importante modificação no padrão histórico de votação no PMDB do primeiro (1982) para o segundo pleito em disputa após a redemocratização em nível estadual (1986). Ainda que houvesse logrado vitória nas duas eleições, o partido havia mudado de forma expressiva suas bases eleitorais - de uma agremiação de caráter fortemente urbano para uma penetração mais profunda nas regiões distantes da Grande São Paulo. Este processo a autora denominou de "interiorização do PMDB".

Em 1994, encerrado o ciclo peemedebista à frente do Estado, com a eleição de uma agremiação dissidente, o PSDB, qual seria o panorama de distribuição de votos em termos geográficos e populacionais do partido que se mantém predominante nas eleições estaduais e de seus principais adversários? A hipótese norteadora deste capítulo baseia-se na assunção de que o predomínio tucano em São Paulo ancora-se sobretudo nos municípios situados no interior paulista. Sua prevalência nos pequenos municípios (os quais localizam-se sobremaneira nas regiões externas à Grande São Paulo) apontaria para este cenário.

De forma a identificar possíveis diferenças neste sentido, adotamos um recorte simplificado entre duas regiões do Estado. Temos ciência de que tal divisão é parcial e encerra também em si possíveis complexidades e diferenças internas as quais não iremos mapear. Entretanto, acreditamos que o recorte proposto e explanado a seguir será suficiente para apontar possíveis diferenças entre as bases sociais (e, neste caso, territoriais) dos principais partidos no Estado de São Paulo.

Adotaremos, neste caso, uma divisão entre dois territórios: a Grande São Paulo e o que denominaremos "interior". No primeiro recorte, trata-se da região composta por 39 municípios (dentre eles, a capital do Estado), responsável por cerca da metade da população paulista (conforme o quadro 35 a seguir) e por 55,8\% do PIB paulista em $2012^{46}$. Foi instituída pela Lei Complementar Federal n ${ }^{\circ}$ 14/1973 e reorganizada

\footnotetext{
${ }^{45}$ Sobre este aspecto, destacamos de maneira pormenorizada no primeiro capítulo e no princípio deste capítulo 3 as contribuições de Ferreira (1964), Weffort (1965) Lamounier (1978), Faria (1978) e Sadek (1987) sobre o tema.

${ }^{46}$ Fundação SEADE - Portal IMP (http://www.imp.seade.gov.br; acesso em 17/09/2014).
} 
recentemente pela Lei Complementar Estadual $n^{\circ} 1.139 / 2011^{47}$. Mais do que o aspecto institucional, optamos por analisar a capital conjuntamente com os municípios de seu entorno pelo fato de compartilharem características socioeconômicas e estarem integrados territorial (conurbação) e fisicamente (por meio de transportes ferroviários, ligações rodoviárias, entre outros).

Em seguida, reunimos o restante dos municípios e regiões paulistas em uma categoria abrangente, a qual denominamos “interior” (composta por 611 municípios). Menos do que o aspecto geográfico (afinal, neste recorte encontram-se municípios do litoral paulista), a distinção específica do interior deve-se pela sua própria condição de reverso da capital. Além disso, seguimos aqui a trilha de outros trabalhos da literatura que também adotaram o mesmo critério de divisão (SADEK; 1987; FERREIRA; 1960; WEFFORT, 1964). Se em parte tal divisão não propiciará aprofundarmo-nos em características e situações peculiares de cada região, por outro permitirá um olhar abrangente sobre o panorama eleitoral paulista no período recente.

Quadro 35 - Distribuição Populacional no Estado de São Paulo (Milhões de Habitantes e Percentual)

\begin{tabular}{ccccccc}
\hline LOCAL & $\mathbf{1 9 9 4}$ & $\mathbf{1 9 9 8}$ & $\mathbf{2 0 0 2}$ & $\mathbf{2 0 0 6}$ & $\mathbf{2 0 1 0}$ & $\mathbf{2 0 1 4}$ \\
\hline $\begin{array}{c}\text { Grande } \\
\text { SP }\end{array}$ & 16,14 & 17,26 & 18,26 & 18,99 & 19,66 & 19,87 \\
& $48,58 \%$ & $48,35 \%$ & $48,17 \%$ & $47,93 \%$ & $47,71 \%$ & $46,58 \%$ \\
Interior & 17,1 & 18,44 & 19,64 & 20,63 & 21,55 & 22,79 \\
& $51,42 \%$ & $51,65 \%$ & $51,83 \%$ & $52,07 \%$ & $52,29 \%$ & $53,42 \%$ \\
& 33,24 & 35,70 & 37,90 & 39,62 & 41,22 & 42,67 \\
TOTAL & $100 \%$ & $100 \%$ & $100 \%$ & $100 \%$ & $100 \%$ & $100 \%$ \\
& & & & & & \\
\hline
\end{tabular}

Fonte: Fundação SEADE

Em termos de performance eleitoral dos principais partidos nestas duas regiões, os resultados agregados estão apresentados no quadro 35 a seguir: 47 Fonte: Subsecretaria de Assuntos Metropolitanos da Casa Civil do Estado de São Paulo
(http://www.sdmetropolitano.sp.gov.br/portalsdm/sao-paulo.jsp; acesso em 02/12/2015). 
Quadro 36 - Porcentagem de Votos Válidos dos Principais Partidos nas Eleições para o Governo do Estado de São Paulo - Grande São Paulo e Interior (1994-2014)

\begin{tabular}{|c|c|c|c|c|c|c|}
\hline$\overline{\mathrm{ANO}}$ & REGIÃO & PSDB & PT & PMDB & PDS/PP & PDT \\
\hline \multirow{2}{*}{1994} & Grande SP & $44,79 \%$ & $17,06 \%$ & $7,21 \%$ & - & $26,34 \%$ \\
\hline & Interior & $48,98 \%$ & $12,56 \%$ & $15,55 \%$ & - & $17,93 \%$ \\
\hline \multirow{2}{*}{1998} & Grande SP & $21,55 \%$ & $24,19 \%$ & $2,64 \%$ & $31,25 \%$ & $19,52 \%$ \\
\hline & Interior & $24,38 \%$ & $20,8 \%$ & $5,98 \%$ & $33,19 \%$ & $14,68 \%$ \\
\hline \multirow{2}{*}{2002} & Grande SP & $35,94 \%$ & $32,67 \%$ & $*$ & $23,02 \%$ & - \\
\hline & Interior & $40,54 \%$ & $32,23 \%$ & $*$ & $19,78 \%$ & - \\
\hline \multirow{2}{*}{2006} & Grande SP & $51,41 \%$ & $36,19 \%$ & $4,87 \%$ & - & $2,71 \%$ \\
\hline & Interior & $63,82 \%$ & $27,31 \%$ & $4,28 \%$ & - & $1,36 \%$ \\
\hline \multirow{2}{*}{2010} & Grande SP & $46,23 \%$ & $37,89 \%$ & - & $6,64 \%$ & \\
\hline & Interior & $54,39 \%$ & $32,39 \%$ & - & $4,21 \%$ & - \\
\hline \multirow{2}{*}{2014} & Grande SP & $51,46 \%$ & $22,72 \%$ & $21,96 \%$ & - & - \\
\hline & Interior & $62,53 \%$ & $14,20 \%$ & $21.15 \%$ & - & - \\
\hline
\end{tabular}

(*) Nesta eleição, o candidato peemedebista foi substituído no meio da disputa Fernando Morais deu lugar a Lamartine Posella - e obteve apenas 1,32\% dos votos válidos - razão pela qual não efetuamos a distribuição acima.

Fonte: TSE

É possível observar, no quadro acima, que o PSDB sempre obteve desempenho melhor no interior do que na Grande São Paulo, sendo inverso o padrão do PT. É importante notar, porém, que o partido tucano sempre foi sufragado de maneira expressiva na região metropolitana da Capital, sendo superado pelo adversário petista na região apenas em um pleito $(1998)^{48}$.

\footnotetext{
${ }^{48}$ Em relação ao PMDB, verifica-se, uma vez mais, que o partido obtinha maior apoio no interior do Estado, característica essa que se dissipa nos pleitos de 2006 e de 2014.
} 
De forma a nos aprofundarmos na análise regional do voto, observaremos de maneira pormenorizada a performance dos partidos nessas regiões. Para tanto, adotamos como recorte temporal a eleição de 2002. Como sabemos, em 2002 há uma importante inflexão na vida política nacional, com a vitória da oposição (capitaneada pelo PT) na disputa pela presidência da República. Assim como no capítulo anterior, buscaremos verificar se tal situação teria trazido impactos para as eleições no Estado de São Paulo nesta e nas eleições subsequentes.

Adotamos metodologia semelhante de distribuição de zonas eleitorais e municípios: utilizamos um índice classificatório de forma a "ranquear" as zonas eleitorais ou municípios (o menor território eleitoral) em termos da escolaridade média do eleitorado ${ }^{49}$. A elaboração deste índice teve por objetivo construir uma forma de distinção das diferentes zonas ou municípios em termos do nível de desenvolvimento médio do eleitorado da região. Dessa forma, é possível verificar se a elevação do nível de desenvolvimento das localidades relaciona-se com o desempenho dos principais partidos no Estado ao longo dos pleitos analisados (2002, 2006, 2010 e 2014). Apresentamos os dados de duas formas distintas: por meio de gráficos de dispersão e por correlações (r de Pearson) para cada quartil de escolaridade média do eleitorado.

É relevante ressaltar aqui a advertência de Vilmar Faria (1978) quando efetuamos análises eleitorais a partir das características socioeconômicas de um território. Segundo o autor, não se pode inferir que determinados eleitores votaram em um candidato a partir da relação encontrada entre determinadas características locais e o desempenho de uma agremiação. A interpretação correta seria ver nesta associação um indicador da existência de contexto que se mostrou favorável a determinado partido ou candidato. Nas palavras do autor:

“(...) O principal cuidado deve consistir em não fazer inferências sobre os determinantes do comportamento eleitoral do indivíduo a partir dos resultados encontrados para as unidades ecológicas (...). Esse tipo de falácia, conhecido como falácia ecológica, obscurece e tergiversa os resultados de uma análise ecológica.” (FARIA, 1978, p. 209).

\footnotetext{
${ }^{49}$ Explicamos de maneira detalhada, na nota 22 do capítulo anterior, a forma de construção deste índice.
} 
Feitas essas ressalvas, iniciamos o percurso pelas eleições de 2002. No gráfico abaixo estão expostos os percentuais de votação do PSDB em relação ao nível de escolaridade média do eleitorado na região da Grande São Paulo.

\section{Gráfico 9 - Percentual de Votos Válidos x Escolaridade Média das Zonas Eleitorais / Municípios (Grande São Paulo) - $1^{\circ}$ Turno 2002 - PSDB}

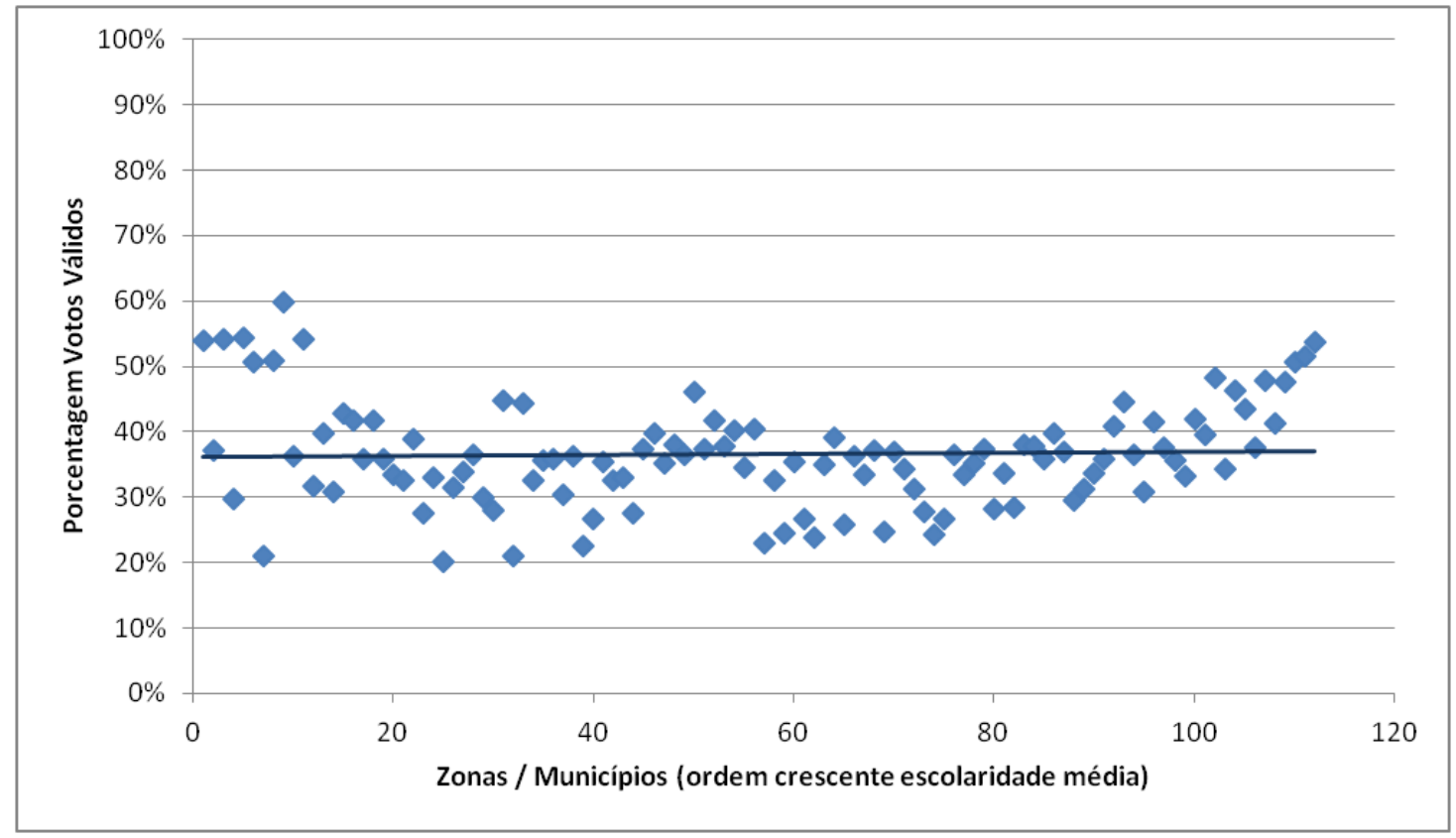

Fonte: TSE

Como se pode observar, o padrão de votação do PSDB se assemelha levemente a uma letra "U". No primeiro extremo, o padrão do partido é levemente decrescente, ao passo que no quadrante final sua votação é francamente crescente. Ao meio, um padrão mais homogêneo de votação no partido. Assim, a curva linear de votos tucanos na Grande São Paulo é praticamente horizontal.

No quadro a seguir, observamos que, em linhas gerais, há uma pequena correlação positiva entre o voto no partido e o nível de escolaridade das localidades. Quando dividido pelos quartis, observamos que tal movimento só se inicia a partir do segundo quadrante (com menor significância estatística) e torna-se elevado no quarto quartil. Interessante notar que, nos locais menos escolarizados (e, por meio de nossa proxy, menos desenvolvidos), o desempenho tucano é descendente. 
Quadro 37- Correlações ( $R$ de Pearson) entre percentual de votos válidos e Escolaridade Média das Zonas Eleitorais / Municípios (Grande São Paulo) - $\mathbf{1}^{\circ}$ Turno 2002 - PSDB

\begin{tabular}{ccccc}
\hline GERAL & $\mathbf{1}^{\mathbf{0}}$ Quartil & $\mathbf{2}^{\mathbf{0}}$ Quartil & $\mathbf{3}^{\mathbf{0}}$ Quartil & $\mathbf{4}^{\mathbf{0}}$ Quartil \\
\hline $\mathbf{0 , 2 1 3}$ & $-0,493$ & 0,392 & 0,318 & 0,776 \\
$(\mathbf{0 , 0 2})$ & $(0,00)$ & $(0,03)$ & $(0,09)$ & $(0,00)$ \\
$* *$ & $* * *$ & $* *$ & $*$ & $* * *$ \\
\hline$* \mathrm{p}<0,1 ; * * \mathrm{p}<0,05 ; * * * \mathrm{p}<0,01$. & &
\end{tabular}

Fonte: TSE

O PT, por sua vez, possui desempenho inverso na Grande São Paulo. Conforme se pode depreender do gráfico a seguir, o partido possui maiores dificuldades nos dois extremos, ou seja, nos locais com níveis de escolaridade média menores e maiores do eleitorado.

Gráfico 10 - Percentual de Votos Válidos x Escolaridade Média das Zonas Eleitorais / Municípios (Grande São Paulo) - $1^{\circ}$ Turno 2002 - PT

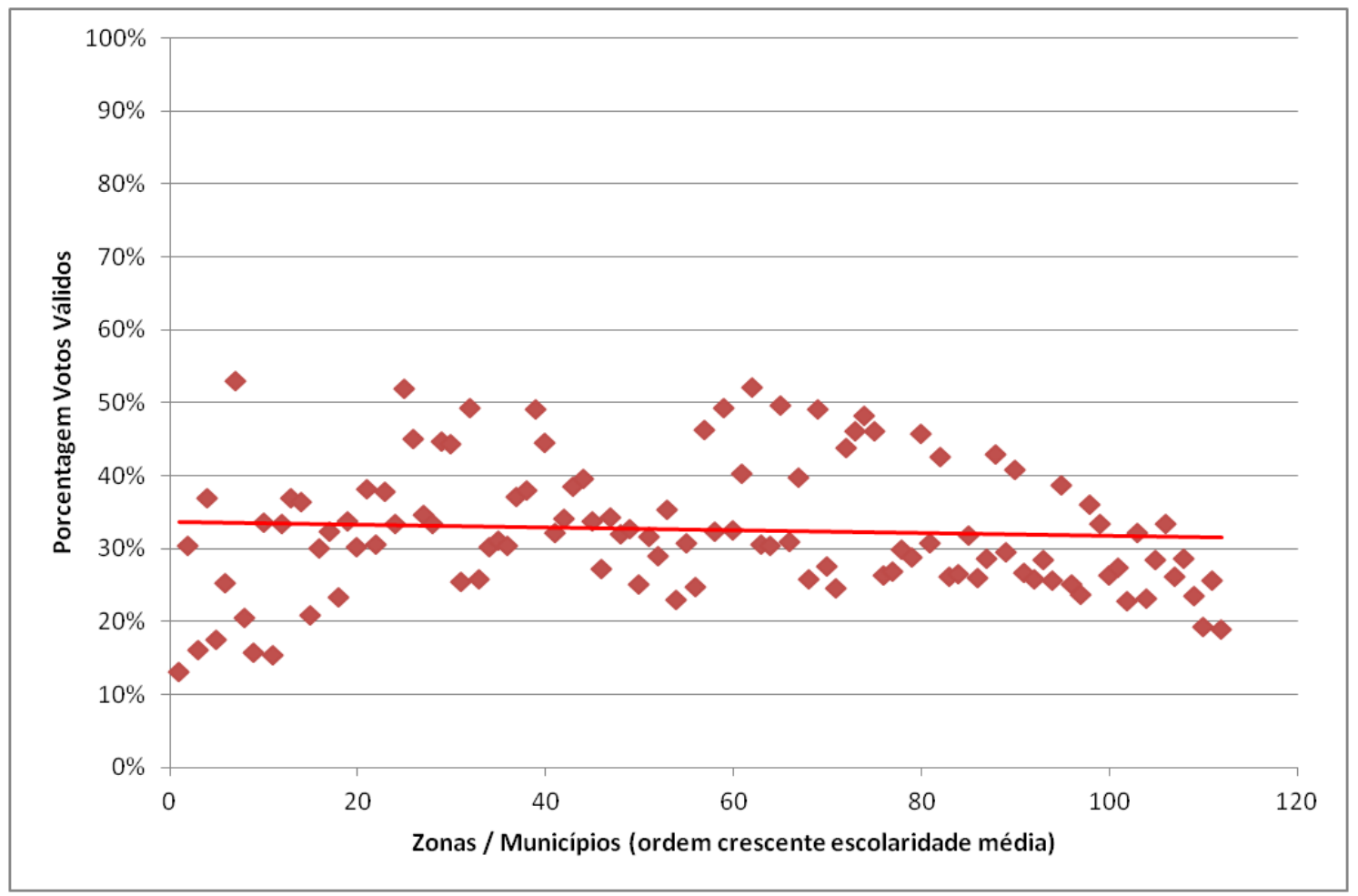

Fonte: TSE 
Quadro 38- Correlações ( $R$ de Pearson) entre percentual de votos válidos e Escolaridade Média das Zonas Eleitorais / Municípios (Grande São Paulo) - $\mathbf{1}^{\circ}$ Turno 2002 - PT

\begin{tabular}{ccccc}
\hline GERAL & $\mathbf{1}^{\mathbf{0}}$ Quartil & $\mathbf{2}^{\mathbf{0}}$ Quartil & $\mathbf{3}^{\mathbf{0}}$ Quartil & $\mathbf{4}^{\mathbf{0}}$ Quartil \\
\hline $\mathbf{- 0 , 1 8 5}$ & 0,483 & $-0,431$ & $-0,274$ & $-0,504$ \\
$(\mathbf{0 , 0 4 )}$ & $(0,00)$ & $(0,02)$ & $(0,15)$ & $(0,00)$ \\
$* *$ & $* * *$ & $* *$ & & $* * *$ \\
\hline$* \mathrm{p}<0,1 ; * * \mathrm{p}<0,05 ; * * * \mathrm{p}<0,01$ & & &
\end{tabular}

Fonte: TSE

No quadro acima, podemos observar que a votação do partido tem uma dependência negativa considerável no primeiro quadrante, bem como moderada no segundo. Por outro lado, é crescente o apoio ao partido à medida em que se eleva o nível de escolaridade média das localidades situadas no primeiro quartil. Curioso notar que, no terceiro quadrante, não encontramos significância estatística no coeficiente de correlação - o que indica um padrão aleatório ou homogêneo de votos no partido e se coaduna com o perfil mais vinculado ao eleitorado de classe média do partido até 2002.

Assim, PSDB e PT obtinham padrões relativamente homogêneos de sufrágio na Grande São Paulo no pleito de 2002.

Elaboramos os mesmos testes para o PDS/PP na Grande São Paulo, conforme o gráfico 10 e o quadro 37 abaixo. Neste caso, verificamos que, em conjunto, Maluf obtinha uma dependência moderada de votação à medida em que cresciam os níveis de escolaridade média das localidades. Não há diferenças de monta, porém, dentro de cada quartil (as correlações apresentam baixos coeficientes ou não têm significância estatística). 
Gráfico 11 - Percentual de Votos Válidos x Escolaridade Média das Zonas

Eleitorais / Municípios (Grande São Paulo) - $1^{0}$ Turno 2002 - PDS/PP

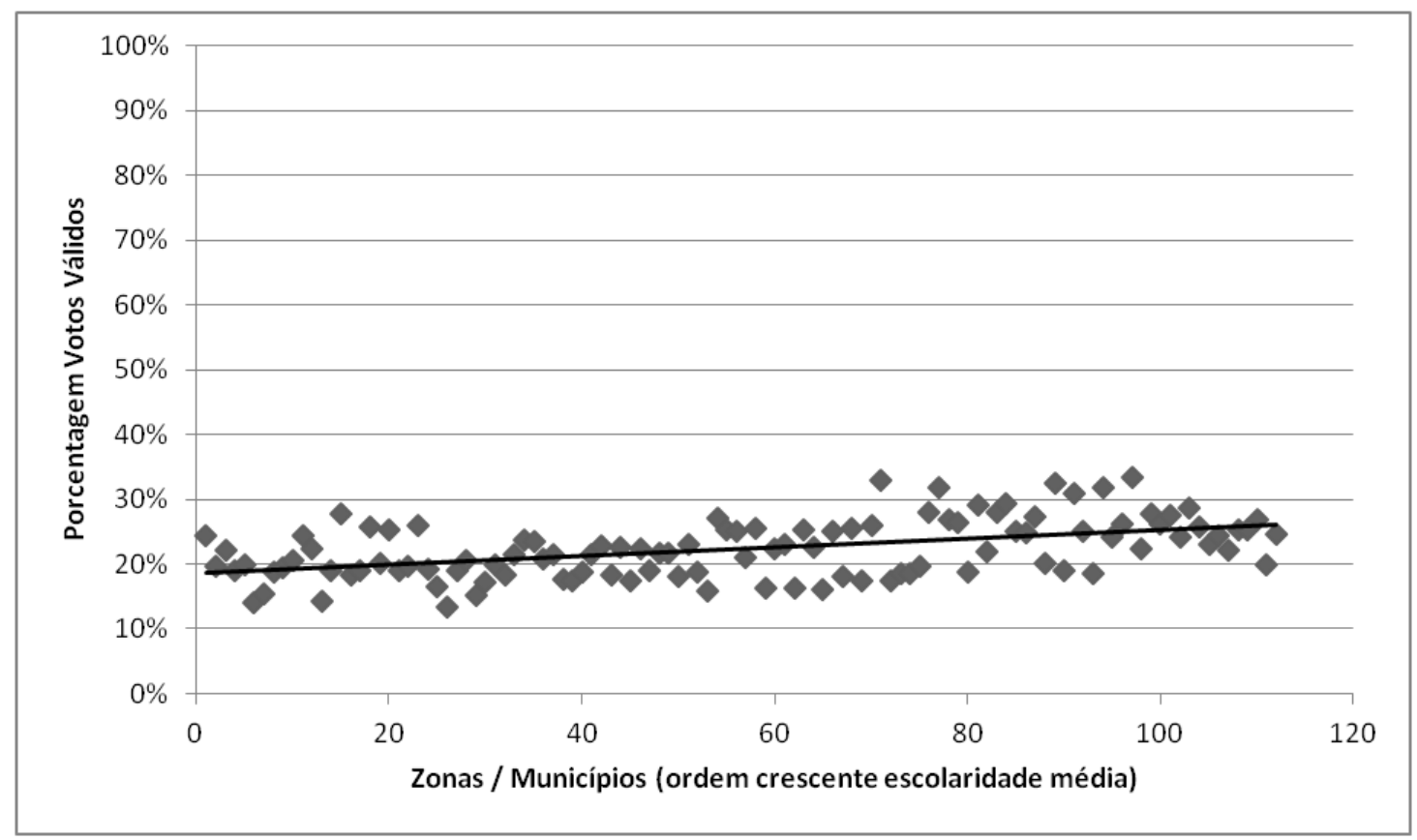

Fonte: TSE

Quadro 39 - Correlações ( $R$ de Pearson) entre percentual de votos válidos e Escolaridade Média das Zonas Eleitorais / Municípios (Grande São Paulo) - $1^{\circ}$ Turno 2002 - PDS/PP

\begin{tabular}{ccccc}
\hline GERAL & $\mathbf{1}^{\mathbf{0}}$ Quartil & $\mathbf{2}^{\mathbf{0}}$ Quartil & $\mathbf{3}^{\mathbf{0}}$ Quartil & $\mathbf{4}^{\mathbf{0}}$ Quartil \\
\hline $\mathbf{0 , 4 3 9}$ & $-0,052$ & 0,341 & 0,348 & $-0,15$ \\
$(\mathbf{0 , 0})$ & $(0,78)$ & $(0,07)$ & $(0,06)$ & $(0,44)$ \\
$* * *$ & & $*$ & $*$ & \\
\hline$* \mathrm{p}<0,1 ; * * \mathrm{p}<0,05 ; * * * \mathrm{p}<0,01$ & & &
\end{tabular}

Fonte: TSE

No interior do Estado, o quadro é diverso. O PSDB possui índices de votação mais voláteis em termos de escolaridade média dos locais (em todos os quartis não houve correlações significativas), com uma tendência de ligeira queda no conjunto. Assim, há maior apoio ao partido tucano nos locais menos desenvolvidos do interior do Estado. 
Gráfico 12 - Percentual de Votos Válidos x Escolaridade Média das Zonas

Eleitorais / Municípios (Interior) - $1^{\circ}$ Turno 2002 - PSDB

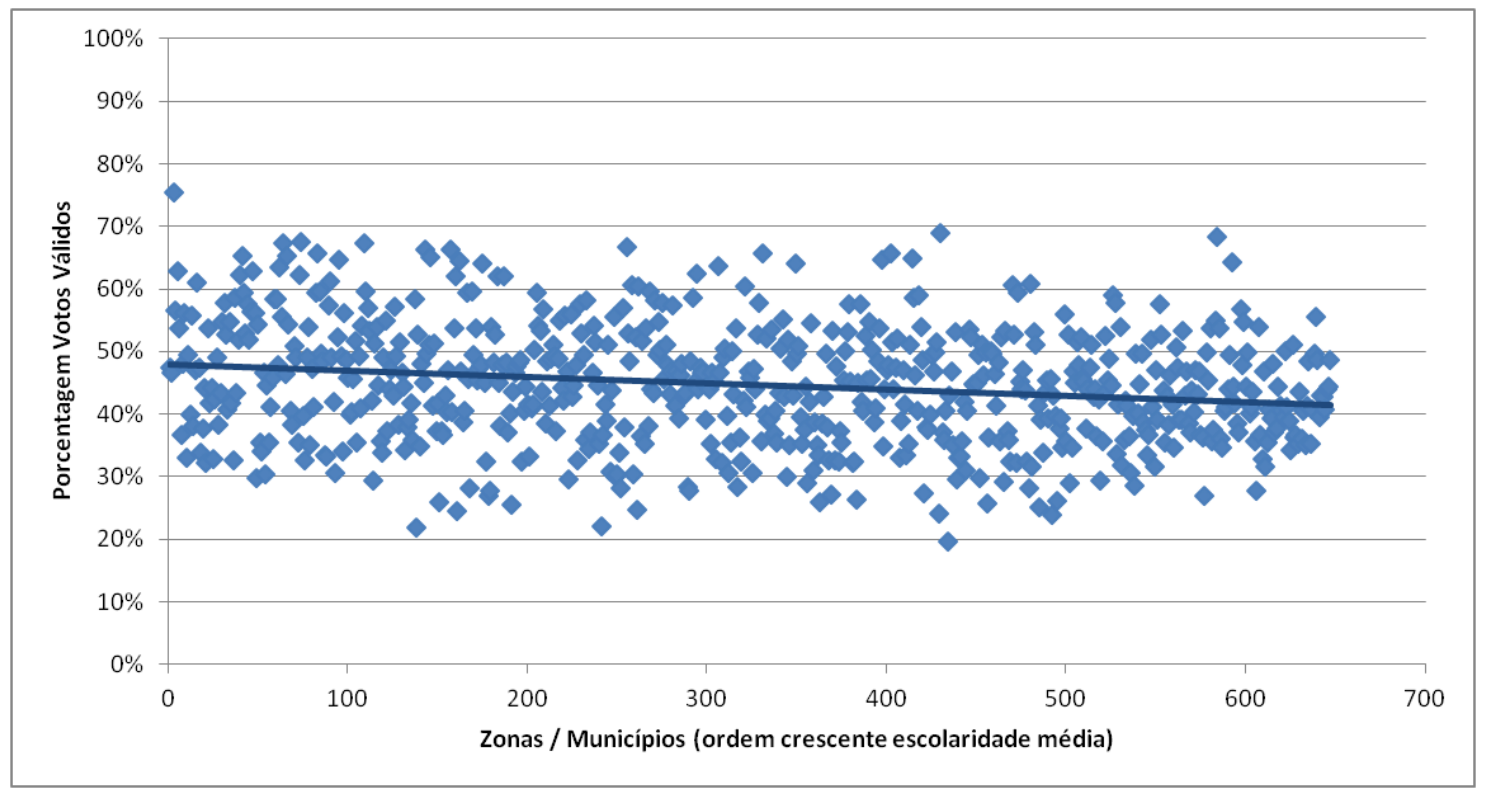

Fonte: TSE

Quadro 40 - Correlações (R de Pearson) entre percentual de votos válidos e Escolaridade Média das Zonas Eleitorais / Municípios (Interior) - $1^{\circ}$ Turno 2002 PSDB

\begin{tabular}{ccccc}
\hline GERAL & $\mathbf{1}^{\mathbf{0}}$ Quartil & $\mathbf{2}^{\mathbf{0}}$ Quartil & $\mathbf{3}^{\mathbf{0}}$ Quartil & $\mathbf{4}^{\mathbf{0}}$ Quartil \\
\hline $\mathbf{- 0 , 1 7 2}$ & $-0,1$ & $-0,04$ & $-0,009$ & 0,066 \\
$(\mathbf{0 , 0})$ & $(0,20)$ & $(0,60)$ & $(0,90)$ & $(0,40)$ \\
$* * *$ & & & \\
\hline$* \mathrm{p}<0,1 ; * * \mathrm{p}<0,05 ; * * * \mathrm{p}<0,01$ & & &
\end{tabular}

Fonte: TSE

O PT, uma vez mais, é o exato inverso: o partido apresenta coeficiente médio de correlação positiva entre seu desempenho eleitoral e a escolaridade média das localidades eleitorais. Não há, porém, variações maiores quando subdividimos estes segmentos em quartis. Observa-se, assim, que o partido obtém também no interior um percentual maior de votação à medida em que avançam as condições socioeconômicas dos locais analisados. 
Gráfico 13 - Percentual de Votos Válidos x Escolaridade Média das Zonas

Eleitorais / Municípios (Interior) - 10 Turno 2002 - PT

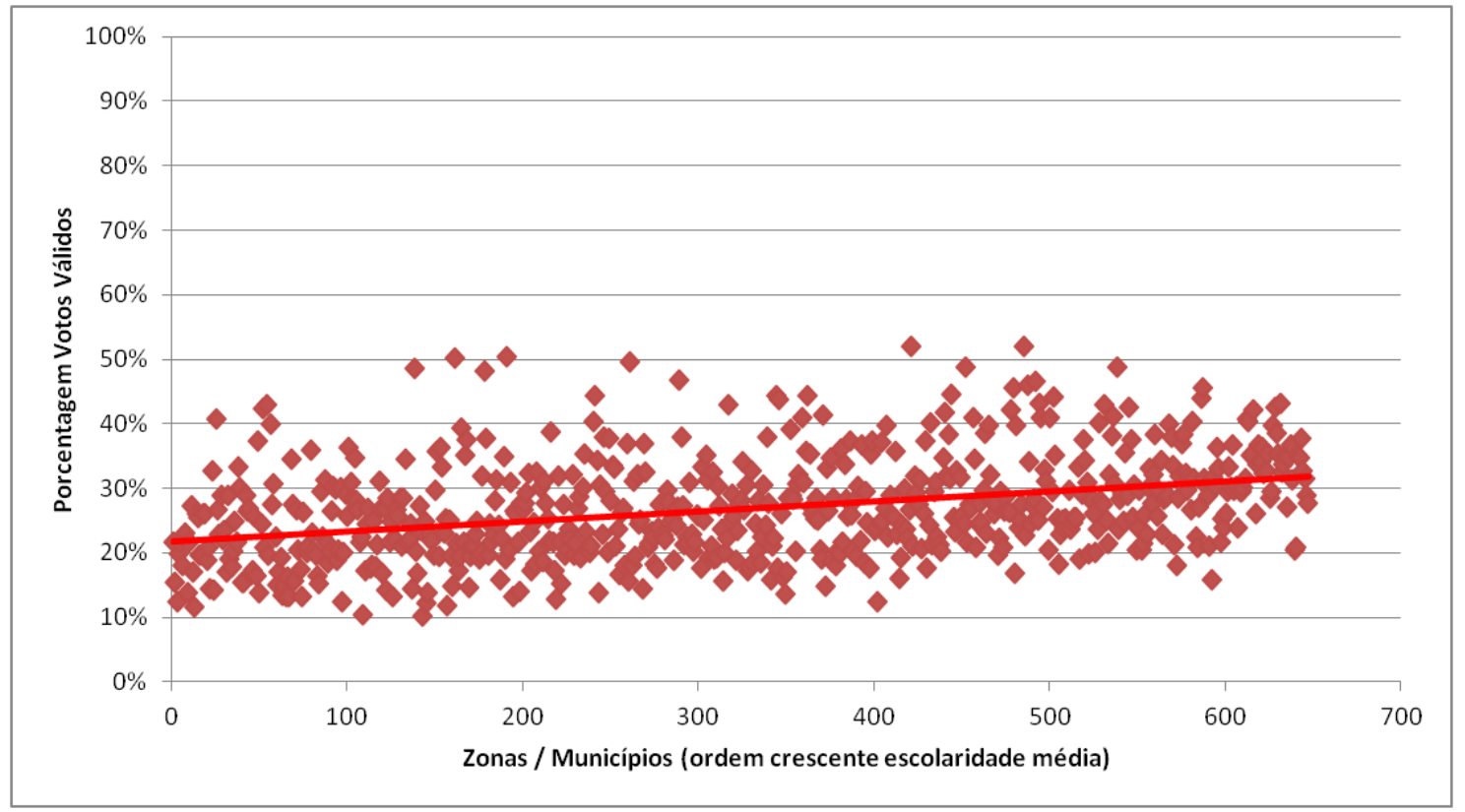

Fonte: TSE

Quadro 41 - Correlações (R de Pearson) entre percentual de votos válidos e Escolaridade Média das Zonas Eleitorais / Municípios (Interior) - $1^{\circ}$ Turno 2002 - PT

\begin{tabular}{ccccc}
\hline GERAL & $\mathbf{1}^{\mathbf{0}}$ Quartil & $\mathbf{2}^{\mathbf{0}}$ Quartil & $\mathbf{3}^{\mathbf{0}}$ Quartil & $\mathbf{4}^{\mathbf{0}}$ Quartil \\
\hline $\mathbf{0 , 3 4 7}$ & 0,141 & 0,003 & 0,125 & 0,082 \\
$(\mathbf{0 , 0})$ & $(0,07)$ & $(0,96)$ & $(0,11)$ & $(0,29)$ \\
$* * *$ & $*$ & & & \\
\hline$* \mathrm{p}<0,1 ; * * \mathrm{p}<0,05 ; * * * \mathrm{p}<0,01$ & & &
\end{tabular}

Fonte: TSE

Por fim, o desempenho de Maluf no interior é inverso ao da região metropolitana da Capital: há uma pequena queda no suporte ao candidato do PDS/PP à medida em que avançam os níveis de escolaridade médio dos eleitores. Percebe-se, assim, uma grande homogeneidade na distribuição de votos malufistas ao longo dos locais analisados. 
Gráfico 14 - Percentual de Votos Válidos x Escolaridade Média das Zonas

Eleitorais / Municípios (Interior) - $1^{\circ}$ Turno 2002 - PDS/PP

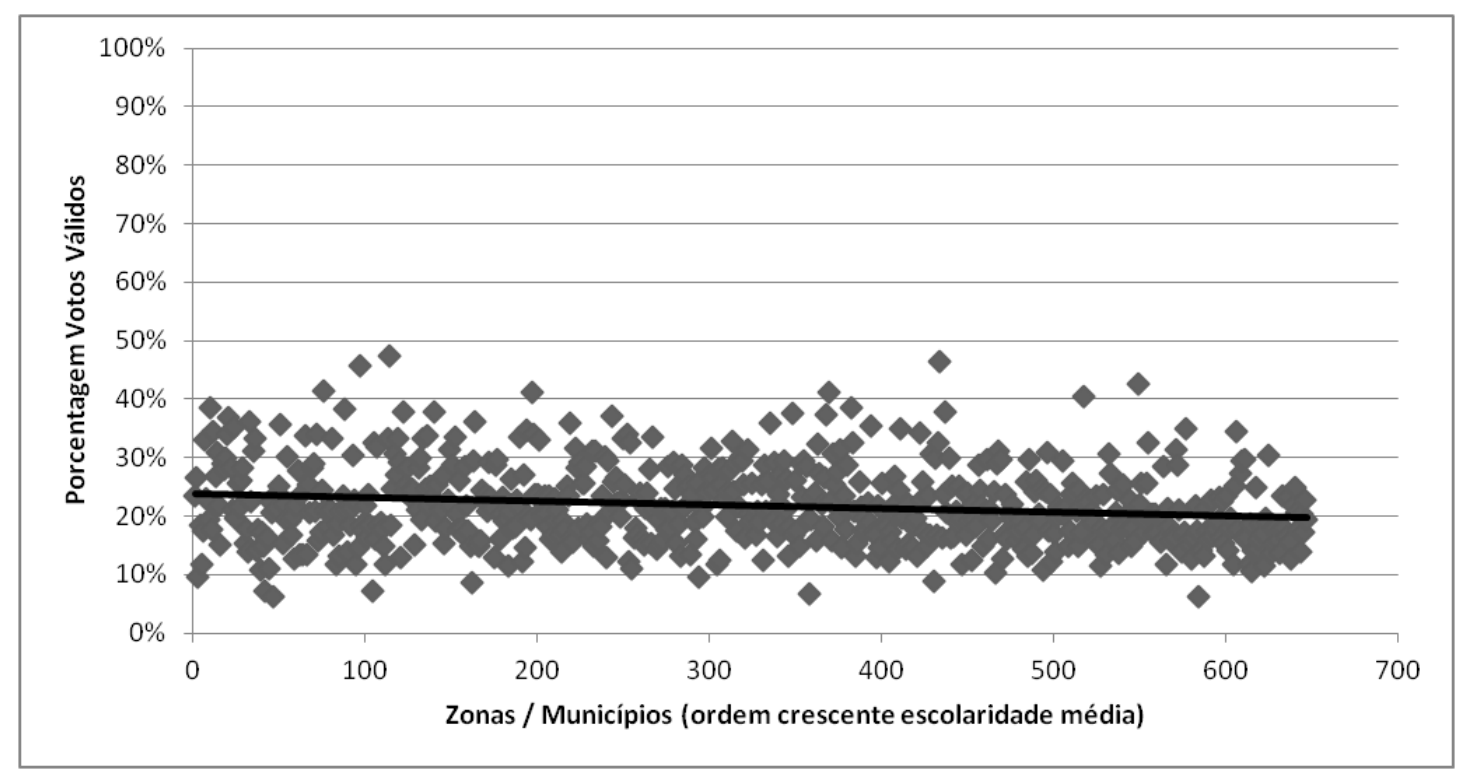

Fonte: TSE

Quadro 42 - Correlações ( $R$ de Pearson) entre percentual de votos válidos e Escolaridade Média das Zonas Eleitorais / Municípios (Interior) - $1^{\circ}$ Turno 2002 PDS/PP

\begin{tabular}{ccccc}
\hline GERAL & $\mathbf{1}^{\mathbf{0}}$ Quartil & $\mathbf{2}^{\mathbf{0}}$ Quartil & $\mathbf{3}^{\mathbf{0}}$ Quartil & $\mathbf{4}^{\mathbf{0}}$ Quartil \\
\hline $\mathbf{- 0 , 1 7 6}$ & $-0,004$ & 0,02 & $-0,133$ & $-0,101$ \\
$(\mathbf{0 , 0})$ & $(0,95)$ & $(0,79)$ & $(0,09)$ & $(0,19)$ \\
$* * *$ & & $*$ & \\
\hline$* \mathrm{p}<0,1 ; * * \mathrm{p}<0,05 ; * * * \mathrm{p}<0,01$ & & &
\end{tabular}

Fonte: TSE

Efetuamos, para o segundo turno, os mesmos testes e análises gráficas apresentadas anteriormente. As informações circunscritas à Grande São Paulo referentes aos dois primeiros colocados, PSDB e PT, são apresentadas a seguir. 
Gráfico 15 - Percentual de Votos Válidos x Escolaridade Média das Zonas

Eleitorais / Municípios (Grande SP) - 20 Turno 2002 - PSDB e PT

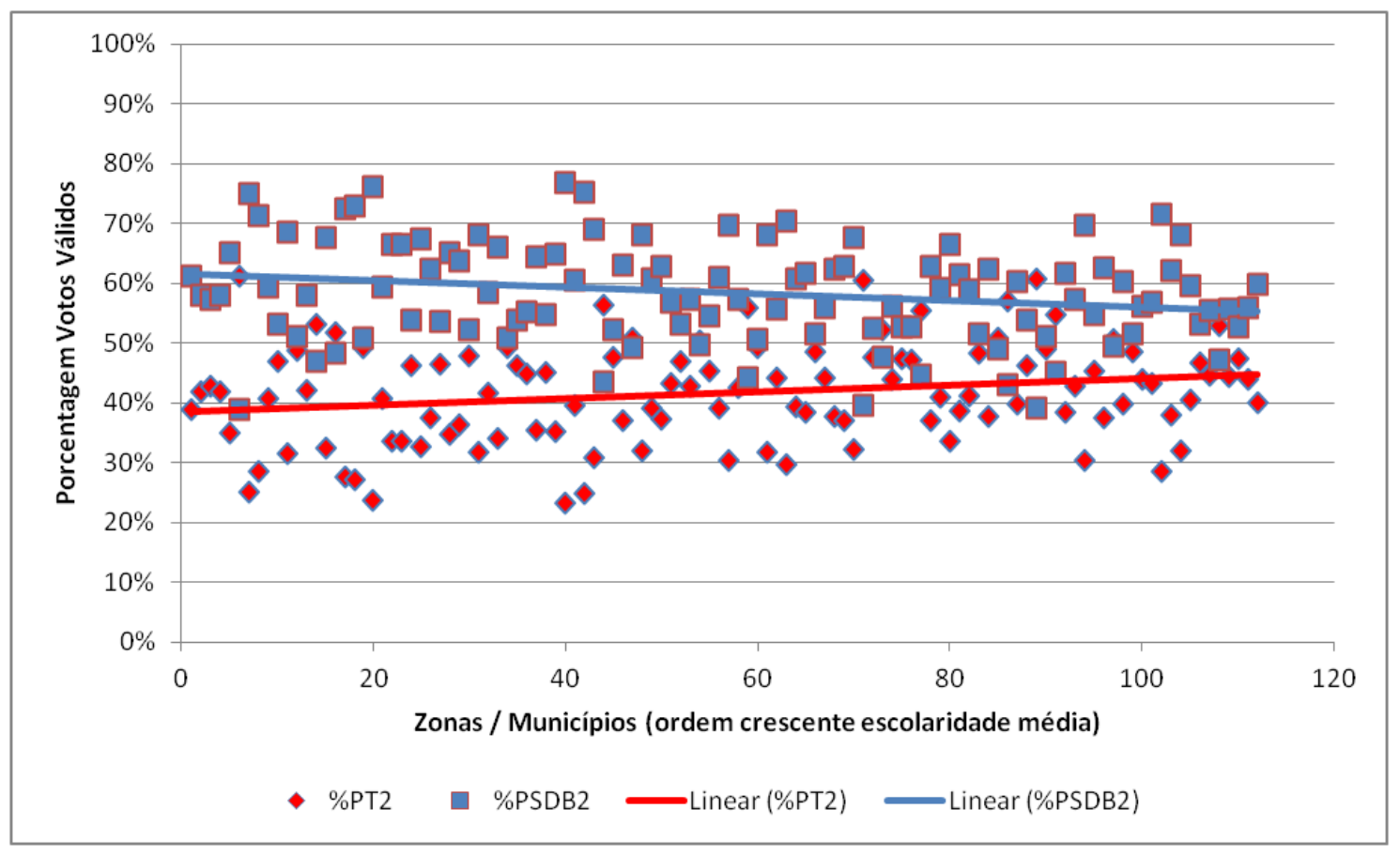

Fonte: TSE

Quadro 43 - Correlações ( $R$ de Pearson) entre percentual de votos válidos e Escolaridade Média das Zonas Eleitorais / Municípios (Grande SP) - 20 Turno 2002 - PSDB e PT

\begin{tabular}{cccccc}
\hline PARTIDO & GERAL & $\mathbf{1}^{\mathbf{0}}$ Quartil & $\mathbf{2}^{\mathbf{0}}$ Quartil & $\mathbf{3}^{\mathbf{0}}$ Quartil & $\mathbf{4}^{\mathbf{0}}$ Quartil \\
\hline \multirow{2}{*}{ PSDB } & $-0,182$ & 0,135 & $-0,184$ & $-0,086$ & 0,159 \\
& $(0,05)$ & $(0,49)$ & $(0,34)$ & $(0,66)$ & $(0,41)$ \\
& $*$ & & & & \\
& 0,182 & $-0,135$ & 0,184 & 0,086 & $-0,159$ \\
PT & $(0,05)$ & $(0,49)$ & $(0,34)$ & $(0,66)$ & $(0,41)$ \\
& $*$ & & & \\
\hline$* \mathrm{p}<0,1 ; * * \mathrm{p}<0,05 ; * * * \mathrm{p}<0,01$ & & &
\end{tabular}

Fonte: TSE

Vale apontar que, por estarmos trabalhando com votos válidos, as performances dos partidos (e os índices de correlação apresentados) são espelhos inversos - afinal o 
não-voto no PSDB significa automaticamente o voto no PT (e vice-versa). Observamos, na segunda rodada eleitoral, que há uma pequena relação de dependência entre o voto no PSDB (negativa) e o PT (positiva) em relação ao nível de desenvolvimento das localidades. Em linhas gerais, porém (e os dados analisados por quartis demonstram este aspecto) não há um padrão claramente identificável no voto dos partidos, sendo a distribuição de votos pouco uniforme. Tal cenário repete-se também no interior do Estado, com a distribuição quase linear de votos entre PSDB e PT ao longo da escala adotada (exceto para o primeiro quartil, no qual há uma pequena correlação negativa entre o voto no PSDB e o nível de escolaridade médio dos locais selecionados - o inverso para o PT). Ao fim e ao cabo, esta imagem pouco nítida e "bagunçada" dos desempenhos dos dois partidos é simbólica por mostrar que, até 2002, eram menos claras as bases eleitorais dos partidos nas duas regiões.

\section{Gráfico 16 - Percentual de Votos Válidos x Escolaridade Média das Zonas \\ Eleitorais / Municípios (Interior) - $2^{\circ}$ Turno 2002 - PSDB e PT}

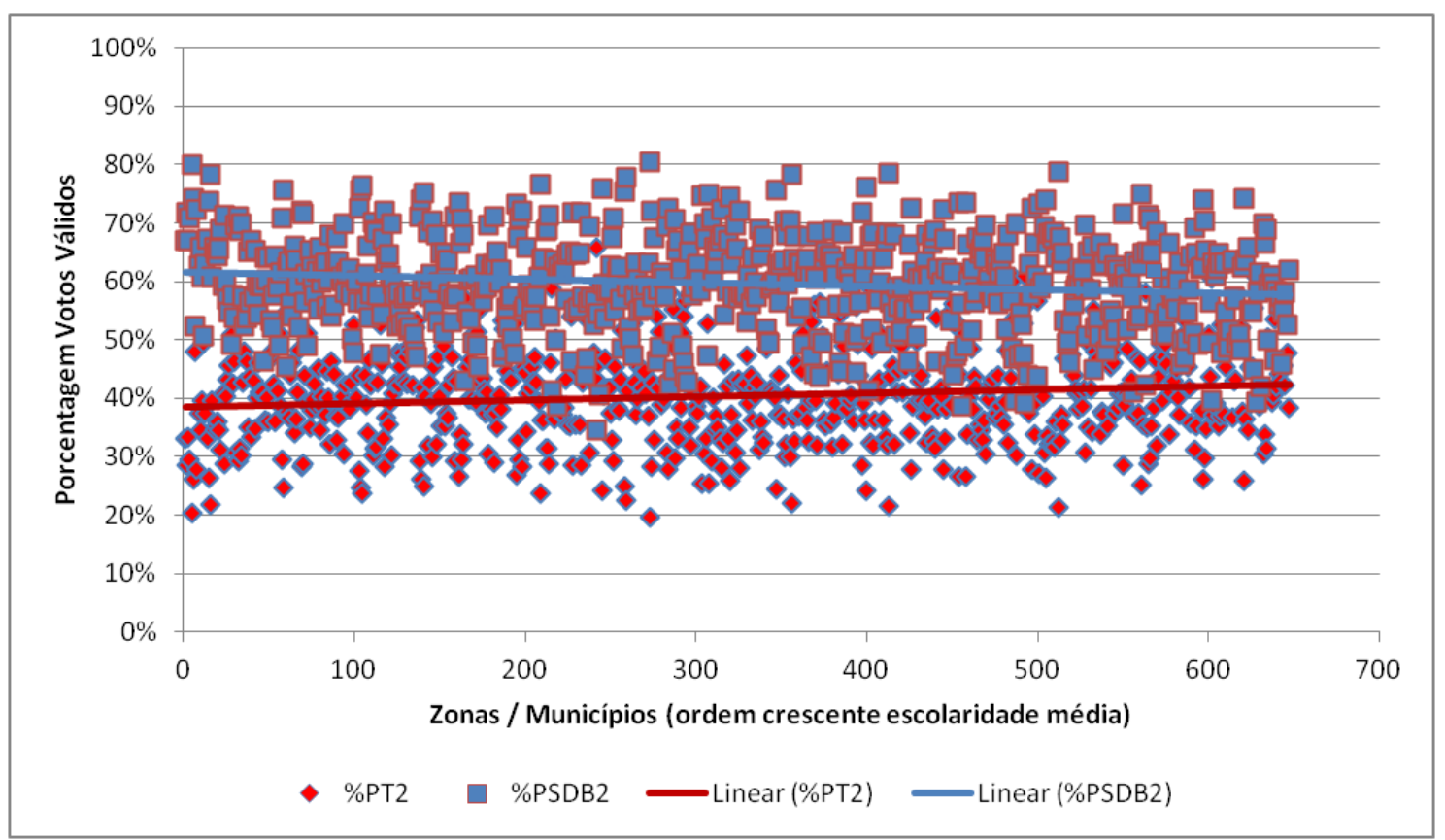

Fonte: TSE

Quadro 44 - Correlações ( $R$ de Pearson) entre percentual de votos válidos e Escolaridade Média das Zonas Eleitorais / Municípios (Interior) - 2 Turno 2002 PSDB e PT

\begin{tabular}{llllll}
\hline PARTIDO GERAL & $1^{\circ}$ Quartil & $2^{\circ}$ Quartil & $3^{\circ}$ Quartil & $4^{\circ}$ Quartil
\end{tabular}




\begin{tabular}{cccccc}
\hline & $-0,156$ & $-0,224$ & 0,132 & $-0,018$ & $-0,092$ \\
& $(0,00)$ & $(0,00)$ & $(0,09)$ & $(0,81)$ & $(0,24)$ \\
$* * *$ & $* * *$ & $*$ & & \\
& 0,156 & 0,224 & $-0,132$ & 0,018 & 0,092 \\
PT & $(0,00)$ & $(0,00)$ & $(0,09)$ & $(0,81)$ & $(0,24)$ \\
& $* * *$ & $* * *$ & $*$ & & \\
\hline$* \mathrm{p}<0,1 ; * * \mathrm{p}<0,05 ; * * * \mathrm{p}<0,01$ & & & &
\end{tabular}

\section{Fonte: TSE}

Conforme vimos no capítulo anterior, as eleições nacionais de 2006 são paradigmáticas na literatura em Ciência Política. Vimos, porém, que para o Estado de São Paulo (observado de maneira global) foi menos perceptível a distinção de bases sociais entre os principais partidos em disputa: o nível de apoio ao PSDB aumentava à medida em que avançavam os níveis socioeconômicos do eleitorado; entretanto, havia já um patamar elevado de apoio ao partido tucano entre as camadas de menor nível de desenvolvimento.

Como a eleição polarizou-se entre PT e PSDB desde o primeiro turno (e até mesmo para facilitar a comparação entre o desempenho dos dois principais partidos), apresentamos as análises para o pleito de 2006 para ambos de maneira conjunta. A seguir, o gráfico e os testes de correlação referentes à Grande São Paulo. 
Gráfico 17 - Percentual de Votos Válidos x Escolaridade Média das Zonas

Eleitorais / Municípios (Grande São Paulo) - $1^{\circ}$ Turno 2006 - PSDB e PT

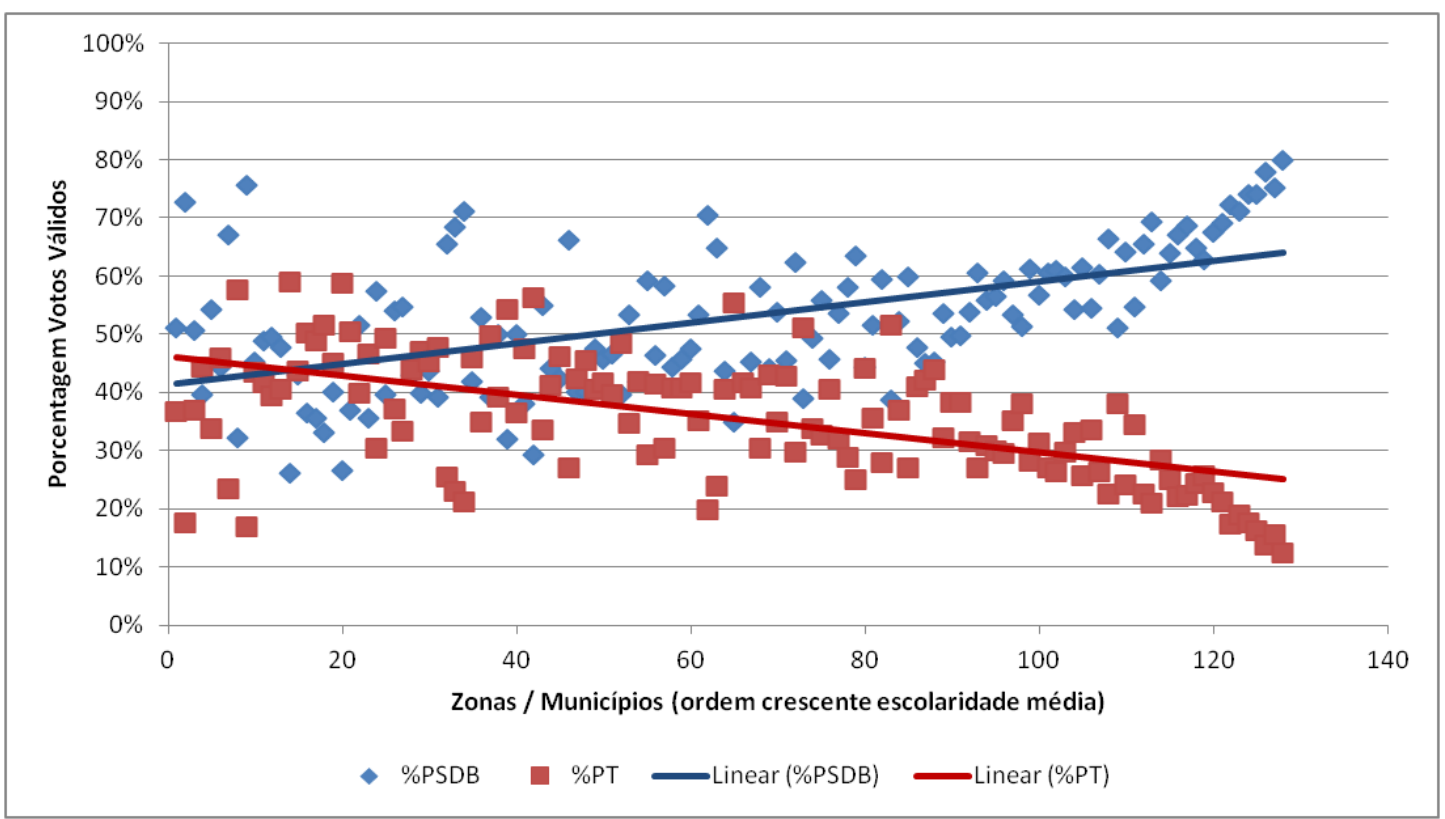

Fonte: TSE

Quadro 45- Correlações ( $R$ de Pearson) entre percentual de votos válidos e Escolaridade Média das Zonas Eleitorais / Municípios (Grande SP) - $1^{\circ}$ Turno 2006 - PSDB e PT

\begin{tabular}{cccccc}
\hline PARTIDO & GERAL & $\mathbf{1}^{\mathbf{0}}$ Quartil & $\mathbf{2}^{\mathbf{o}}$ Quartil & $\mathbf{3}^{\mathbf{0}}$ Quartil & $\mathbf{4}^{\mathbf{0}}$ Quartil \\
\hline \multirow{2}{*}{ PSDB } & 0,617 & $-0,49$ & 0,232 & 0,364 & 0,872 \\
& $(0,0)$ & $(0,00)$ & $(0,19)$ & $(0,04)$ & $(0,00)$ \\
& $* * *$ & $* * *$ & & $* *$ & $* * *$ \\
& $-0,628$ & 0,478 & $-0,285$ & $-0,375$ & $-0,832$ \\
PT & $(0,0)$ & $(0,00)$ & $(0,11)$ & $(0,03)$ & $(0,00)$ \\
& $* * *$ & $* * *$ & & $* *$ & $* * *$ \\
\hline$* \mathrm{p}<0,1 ; * * \mathrm{p}<0,05 ; * * * \mathrm{p}<0,01$ & & & &
\end{tabular}

Fonte: TSE

Nota-se que, neste pleito, há uma configuração nítida de suporte aos partidos à medida em que se avançam os níveis de escolaridade médios dos locais. Há fortes graus de dependência (positivas para o PSDB e negativas para o PT) entre a performance dos 
partidos e o grau de desenvolvimento das localidades - ou seja, quanto maior o nível de escolaridade média, maior o nível de apoio ao PSDB (o inverso para o PT). Observa-se que este movimento é praticamente linear no último quartil. Permanece, porém, a curiosa inversão no primeiro quartil (na qual o PSDB obtém maior suporte nos locais com menores índices, e o PT no movimento inverso).

De forma a compreender esta discrepância, analisamos os dados referentes a tais localidades e verificamos que se tratam dos municípios localizados nas franjas da Grande São Paulo e com características menos "urbanas" da metrópole (Juquitiba, Biritiba-Mirim, Rio Grande da Serra, Salesópolis, São Lourenço da Serra, Salesópolis, entre outros). O que se vê, portanto, é que o candidato tucano prevalece nos locais cujas características sociodemográficas assemelham-se mais ao que aqui denominamos de "interior" do Estado, em cidades menos urbanizadas e com baixa densidade populacional. Se observadas apenas as localidades da capital e suas adjacências (ABCD, Osasco, Taboão da Serra, Francisco Morato, entre outros), verifica-se um padrão mais claro de bases sociais invertidas dos dois principais partidos.

Observado este cenário e feita esta consideração, é preciso matizar os achados do capítulo anterior com estes resultados, pois na Grande São Paulo é possível observar um claro movimento de realinhamento já no pleito de 2006.

No interior paulista, por sua vez, o resultado é diferente. Conforme veremos a seguir, há um "desacoplamento" na curva de performance de PT e PSDB, já que o partido tucano aumenta sua vantagem em relação ao PT em todas as localidades analisadas. Os testes de correlação apontam para um padrão uniforme de votação nos partidos, o que demonstra a ausência de bases sociais nitidamente identificáveis para cada agremiação. Isso significa dizer que o PSDB teve votações expressivas em todas as faixas do eleitorado, sem maiores alterações à medida em que se aumentavam os níveis médios de escolaridade dos locais. Logo, pode-se afirmar que, em relação ao interior do Estado, não há mostras do realinhamento eleitoral ter se configurado. 
Gráfico 18 - Percentual de Votos Válidos x Escolaridade Média das Zonas Eleitorais / Municípios (Interior) - $1^{\circ}$ Turno 2006 - PSDB e PT

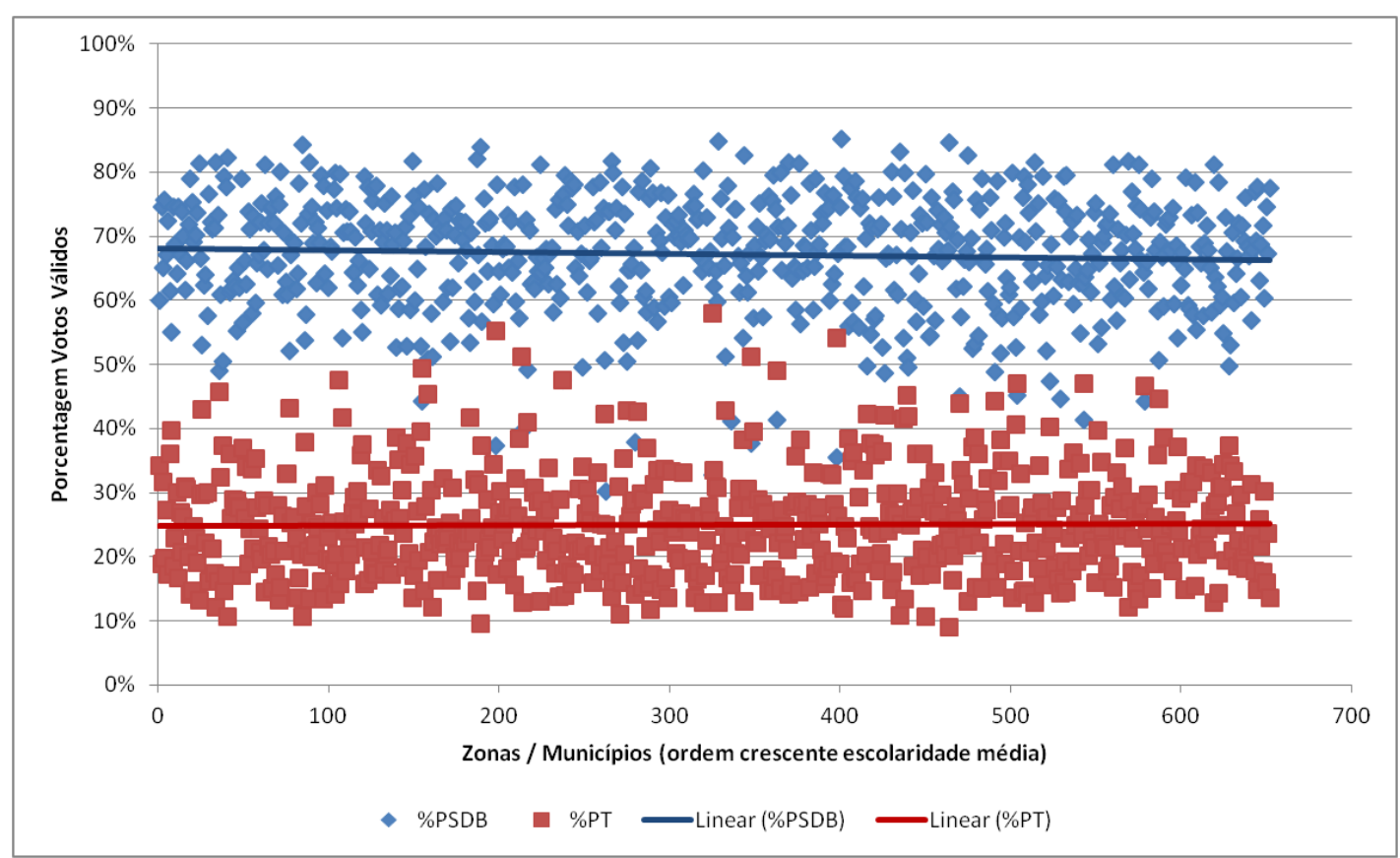

Fonte: TSE

Quadro 46 - Correlações ( $R$ de Pearson) entre percentual de votos válidos e Escolaridade Média das Zonas Eleitorais / Municípios (Interior) - 10 Turno 2006 PSDB e PT

\begin{tabular}{cccccc}
\hline PARTIDO & GERAL & $\mathbf{1}^{\mathbf{0}}$ Quartil & $\mathbf{2}^{\mathbf{0}}$ Quartil & $\mathbf{3}^{\circ}$ Quartil & $\mathbf{4}^{\mathbf{0}}$ Quartil \\
& 0,002 & 0,035 & $-0,037$ & 0,056 & 0,082 \\
PSDB & $(0,95)$ & $(0,65)$ & $(0,63)$ & $(0,47)$ & $(0,29)$ \\
& & & & & \\
& $-0,07$ & $-0,13$ & $-0,002$ & 0,036 & $-0,108$ \\
PT & $(0,04)$ & $(0,09)$ & $(0,97)$ & $(0,64)$ & $(0,16)$ \\
& $* *$ & $*$ & & &
\end{tabular}

$* \mathrm{p}<0,1 ; * * \mathrm{p}<0,05 ; * * * \mathrm{p}<0,01$

Fonte: TSE

No pleito de 2010, o cenário torna-se mais semelhante ao encontrado em âmbito nacional. Na Grande São Paulo, as curvas de desempenho dos partidos ao longo da 
escala de escolaridade média das localidades tornam-se ainda mais nítidas e o grau de dependência do voto em cada agremiação em relação a esta variável é ainda maior. Persiste, porém, a diferenciação encontrada no primeiro quartil (uma vez mais, oriunda das localidades menos populosas e "urbanas" da metrópole - Juquitiba, Biritiba-Mirim, Salesópolis, entre outros). Para o último, a relação é praticamente linear: maior o grau de desenvolvimento médio da localidade, maior o percentual de votação no PSDB (o inverso para o PT).

Gráfico 19 - Percentual de Votos Válidos x Escolaridade Média das Zonas Eleitorais / Municípios (Grande São Paulo) - 10 Turno 2010 - PSDB e PT

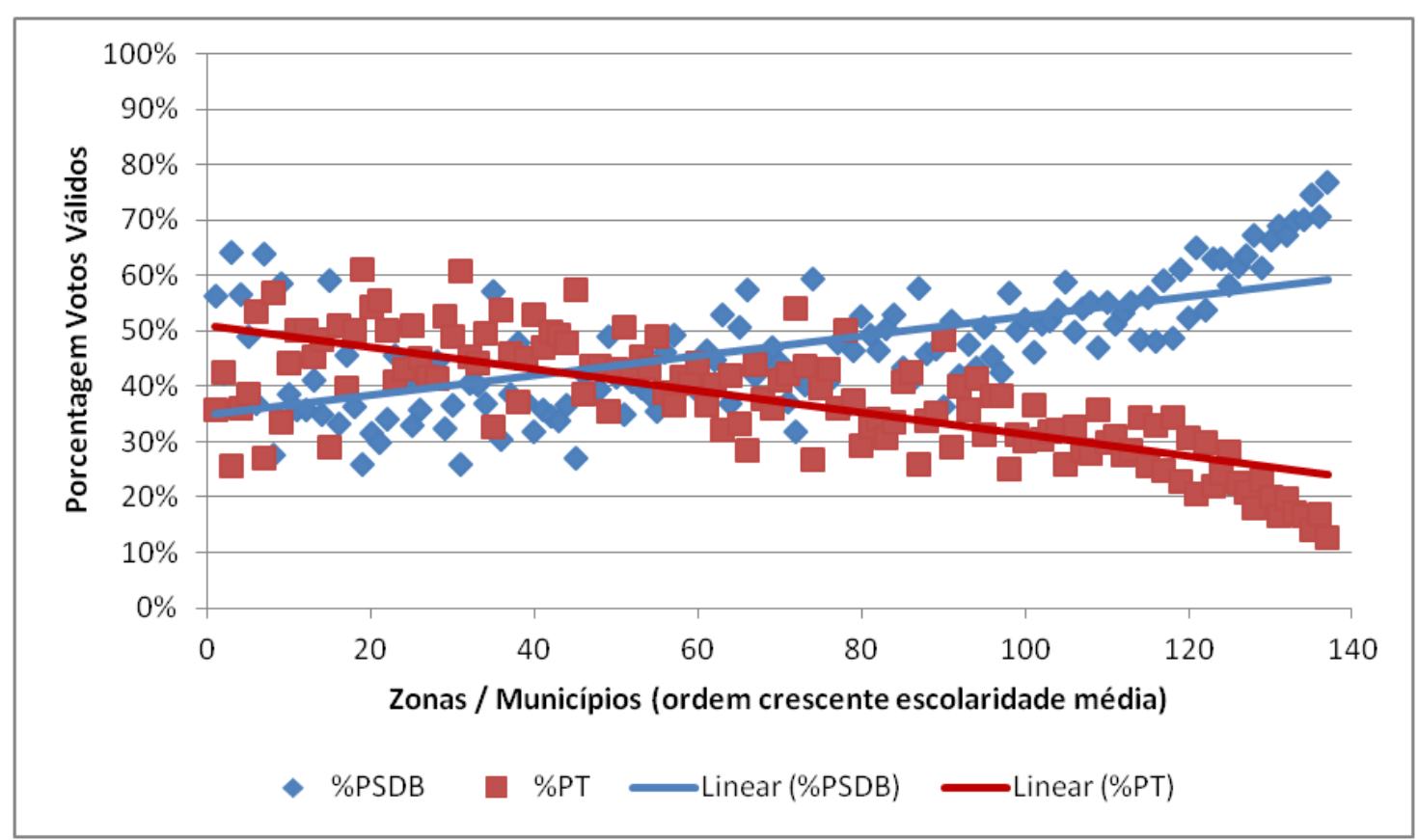

Fonte: TSE 
Quadro 47- Correlações ( $R$ de Pearson) entre percentual de votos válidos e Escolaridade Média das Zonas Eleitorais / Municípios (Grande SP) - 10 Turno 2010 - PSDB e PT

\begin{tabular}{cccccc}
\hline PARTIDO & GERAL & $\mathbf{1}^{\mathbf{0}}$ Quartil & $\mathbf{2}^{\mathbf{0}}$ Quartil & $\mathbf{3}^{\mathbf{0}}$ Quartil & $\mathbf{4}^{\mathbf{0}}$ Quartil \\
\hline \multirow{2}{*}{ PSDB } & 0,733 & $-0,478$ & 0,594 & 0,403 & 0,896 \\
& $(0,0)$ & $(0,00)$ & $(0,00)$ & $(0,01)$ & $(0,00)$ \\
& $* * *$ & $* * *$ & $* * *$ & $* *$ & $* * *$ \\
& $-0,770$ & 0,401 & $-0,619$ & $-0,488$ & $-0,867$ \\
PT & $(0,0)$ & $(0,01)$ & $(0,00)$ & $(0,00)$ & $(0,00)$ \\
& $* * *$ & $* *$ & $* * *$ & $* * *$ & $* * *$ \\
\hline
\end{tabular}

$* \mathrm{p}<0,1 ; * * \mathrm{p}<0,05 ; * * * \mathrm{p}<0,01$

Fonte: TSE

No interior do Estado, o cenário é um pouco diverso daquele encontrado no pleito anterior. Primeiramente, há uma "aproximação" entre as curvas de votação de PSDB e PT. Ao mesmo tempo, o desempenho de ambos parece refletir - ainda que de maneira menos acentuada- a configuração de bases sociais distintas encontrada em âmbito nacional (ao menos para o PT). 


\section{Gráfico 20 - Percentual de Votos Válidos x Escolaridade Média das Zonas Eleitorais / Municípios (Interior) - $1^{\circ}$ Turno 2010 - PSDB e PT}

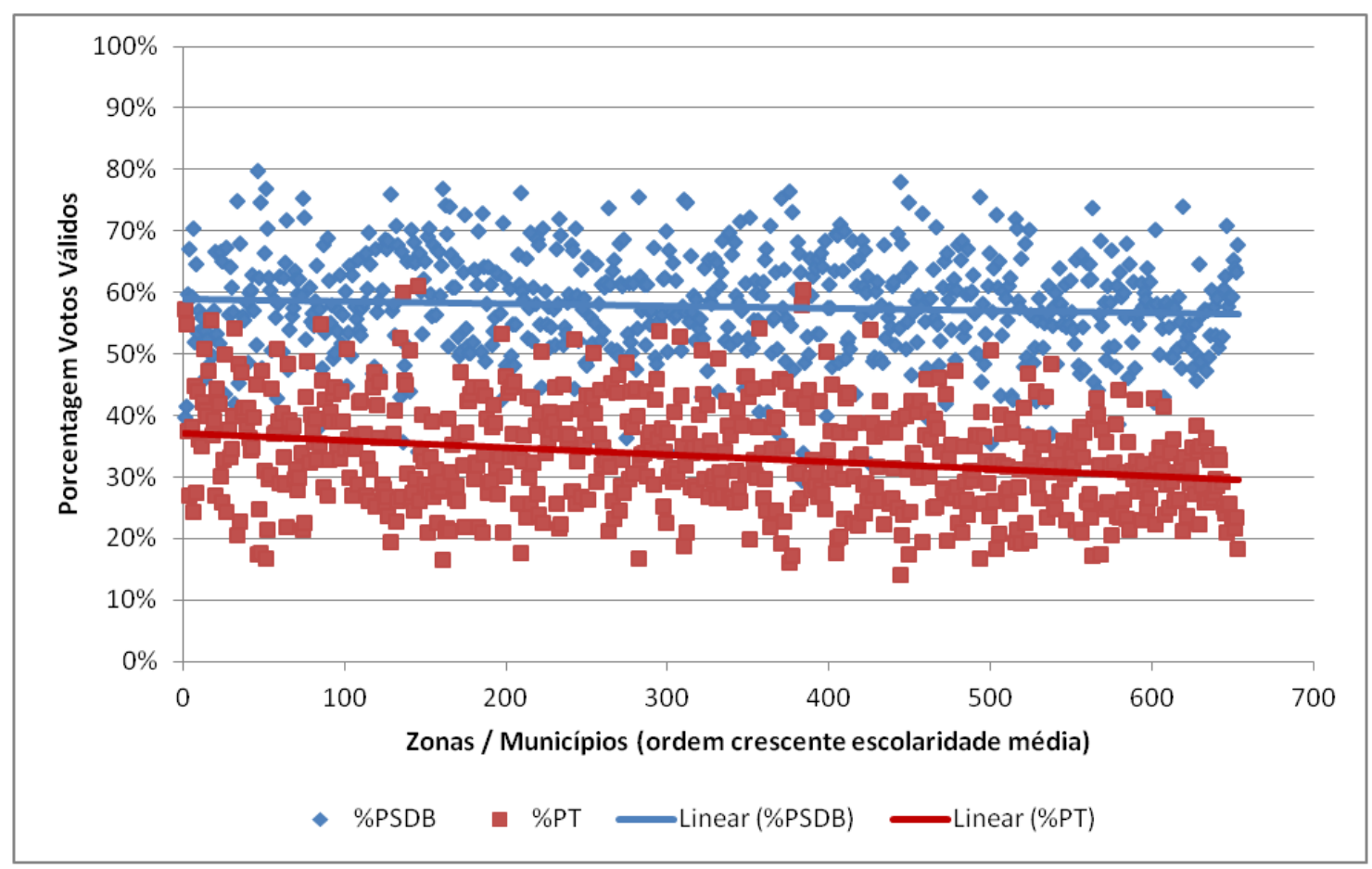

Fonte: TSE

Os testes de correlação abaixo mostram que o desempenho tucano permanece uniforme ao longo de toda a escala. O PT, por sua vez, tem desempenho superior nas localidades menos desenvolvidas (primeiro quartil) e inferior nas regiões de maior nível de escolaridade média (quarto quartil), situação essa semelhante ao seu desempenho em nível nacional. Pode-se dizer, assim, em consonância com o apresentado no capítulo anterior, que as eleições de 2010 configuraram-se como um ensaio de realinhamento eleitoral no Estado de São Paulo, aos moldes do padrão nacional - não apenas na Grande São Paulo, mas também no interior do Estado. 
Quadro 48 - Correlações (R de Pearson) entre percentual de votos válidos e Escolaridade Média das Zonas Eleitorais / Municípios (Interior) - $1^{\circ}$ Turno 2010 PSDB e PT

\begin{tabular}{cccccc}
\hline PARTIDO & GERAL & $\mathbf{1}^{\mathbf{0}}$ Quartil & $\mathbf{2}^{\mathbf{0}}$ Quartil & $\mathbf{3}^{\mathbf{0}}$ Quartil & $\mathbf{4}^{\mathbf{0}}$ Quartil \\
\hline \multirow{2}{*}{ PSDB } & $-0,04$ & 0,195 & $-0,085$ & 0,013 & 0,139 \\
& $(0,29)$ & $(0,01)$ & $(0,27)$ & $(0,86)$ & $(0,07)$ \\
& & $* *$ & & $*$ \\
PT & $-0,280$ & $-0,235$ & 0,03 & $-0,12$ & $-0,255$ \\
& $(0,0)$ & $(0,00)$ & $(0,69)$ & $(0,12)$ & $(0,00)$ \\
& $* * *$ & $* * *$ & & & $* * *$ \\
\hline$* p<0,1 ; * * 0<0,05 ; * * * p<0,01$ & & & &
\end{tabular}

Fonte: TSE

Vale mencionar que, nesta eleição, o PDS/PP voltou a apresentar candidatura, dessa vez sem Paulo Maluf (o candidato foi Celso Russomano). Seu desempenho foi pouco expressivo (teve menos de $5 \%$ dos votos válidos no cômputo geral), razão pela qual não apresentamos os resultados de maneira extensiva. Os testes de correlação apontaram que, na Grande São Paulo, houve relação negativa mediana entre o desempenho do candidato e o nível de escolaridade média das localidades (coeficiente de $-0,467 ; p<0,01$ ). No interior, o cenário foi inverso (coeficiente de 0,360; $p<0,01$ ). Ou seja, Russomano teve maior apoio nas localidades menos desenvolvidas da metrópole paulista, porém foi relativamente melhor nas regiões mais desenvolvidas do interior do Estado de São Paulo.

Nas eleições de 2014, conforme observamos anteriormente, há modificações importantes no contexto eleitoral. Ainda que o PT tenha perdido o segundo posto para o PMDB, optamos por analisar conjuntamente o desempenho petista com o do PSDB, de forma a manter a comparação adotada até aqui. Como veremos a seguir, mesmo na Grande São Paulo há um "descolamento" na votação entre os partidos e os graus de dependência da performance eleitoral em relação ao nível de desenvolvimento local tornam-se menores, ainda que persista a diferenciação de bases entre PSDB e PT. 
Dessa forma, pode-se dizer que a tendência de contornos sociais mais nítidos no desempenho dos principais partidos nacionais que se avizinhava no pleito anterior torna-se menos evidente na Grande São Paulo. O PSDB suplanta o PT em praticamente todas as localidades analisadas ${ }^{50}$.

\section{Gráfico 21 - Percentual de Votos Válidos x Escolaridade Média das Zonas Eleitorais / Municípios (Grande São Paulo) - $1^{\circ}$ Turno 2014 - PSDB e PT}

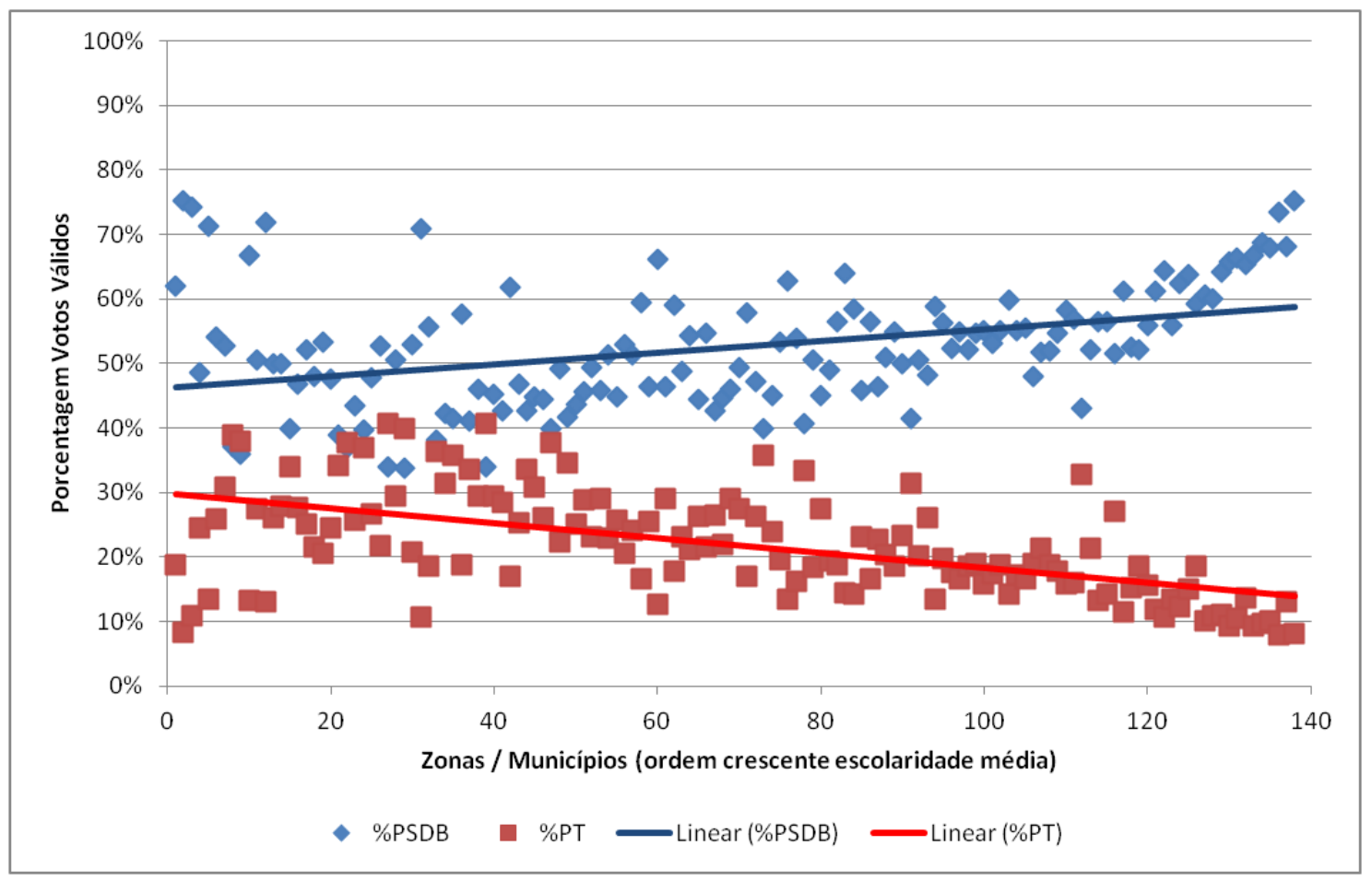

Fonte: TSE

\footnotetext{
${ }^{50}$ Frisamos, uma vez mais, que as localidades à esquerda do gráfico em que a performance tucana é em muito superior retratam municípios singulares da Grande São Paulo (Salesópolis, Juquitiba, BiritibaMirim, entre outros) - municípios esses com características socioeconômicas mais próximas do interior paulista do que da própria região metropolitana em que se encontram.
} 
Quadro 49 - Correlações (R de Pearson) entre percentual de votos válidos e Escolaridade Média das Zonas Eleitorais / Municípios (Grande SP) - 10 Turno 2014 - PSDB e PT

\begin{tabular}{cccccc}
\hline PARTIDOS & GERAL & $\mathbf{1}^{\mathbf{0}}$ Quartil & $\mathbf{2}^{\mathbf{0}}$ Quartil & $\mathbf{3}^{\mathbf{0}}$ Quartil & $\mathbf{4}^{\mathbf{0}}$ Quartil \\
\hline \multirow{2}{*}{ PSDB } & 0,501 & $-0,524$ & 0,242 & 0,236 & 0,877 \\
& $(0,0)$ & $(0,00)$ & $(0,16)$ & $(0,17)$ & $(0,00)$ \\
& $* * *$ & $* * *$ & & & $* * *$ \\
& $-0,584$ & 0,407 & $-0,385$ & $-0,348$ & $-0,645$ \\
PT & $(0,0)$ & $(0,01)$ & $(0,02)$ & $(0,04)$ & $(0,00)$ \\
& $* * *$ & $* *$ & $* *$ & $* *$ & $* * *$ \\
\hline
\end{tabular}

$* \mathrm{p}<0,1 ; * * \mathrm{p}<0,05 ; * * * \mathrm{p}<0,01$

Fonte: TSE

O segundo colocado neste pleito, o PMDB, tem uma curva de votação peculiar. Observa-se que, em certo sentido, seu desempenho assemelha-se ao do PT pré-2002, com maiores dificuldades nos dois extremos do eleitorado. É nas localidades com nível de desenvolvimento médio em que o candidato do PMDB sai-se melhor 
Gráfico 22 - Percentual de Votos Válidos x Escolaridade Média das Zonas Eleitorais / Municípios (Grande São Paulo) - $1^{\circ}$ Turno 2014 - PMDB

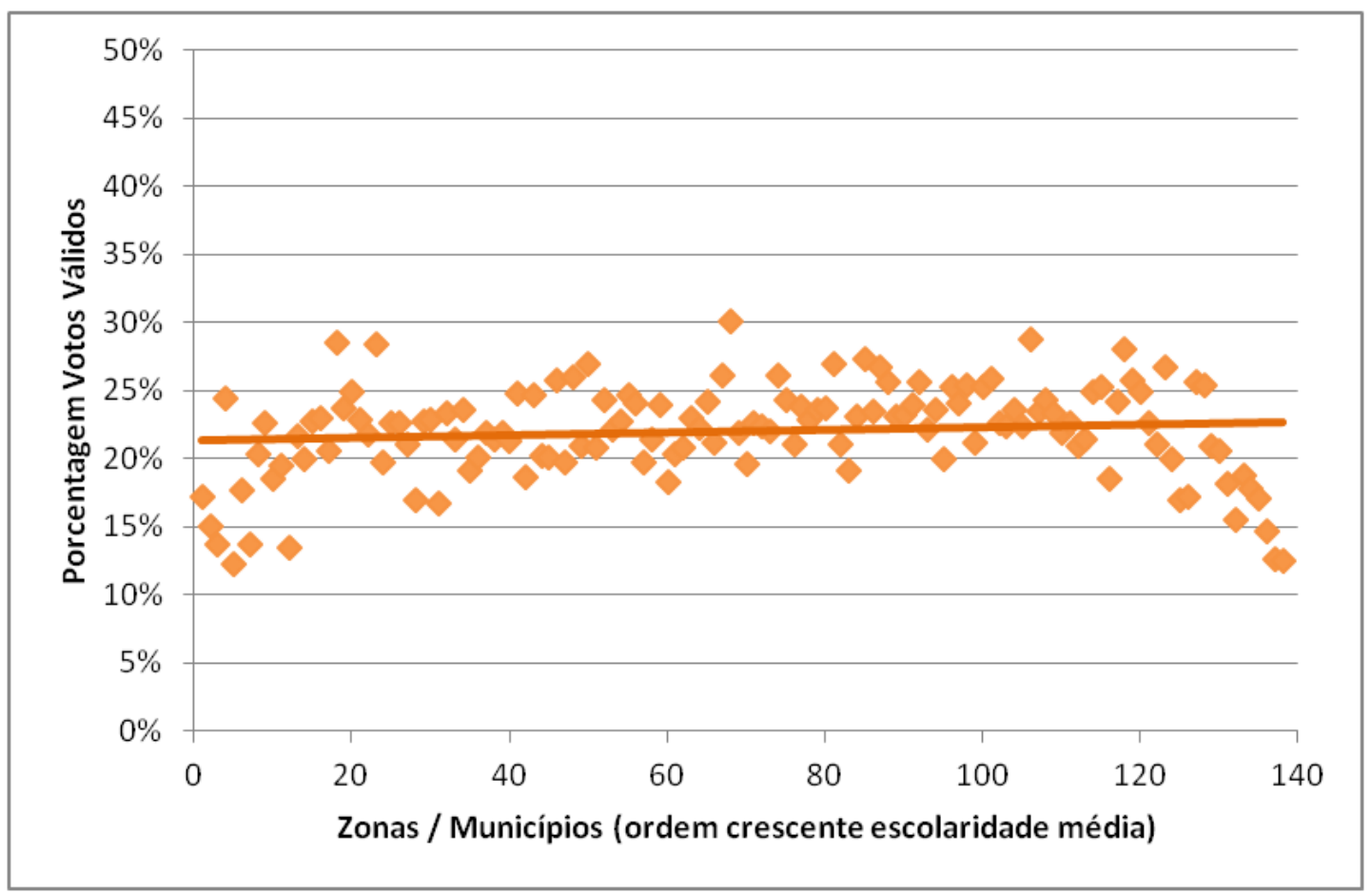

Fonte: TSE

Quadro 50 - Correlações ( $R$ de Pearson) entre percentual de votos válidos e Escolaridade Média das Zonas Eleitorais / Municípios (Grande SP) - $1^{\circ}$ Turno 2014 - PMDB

\begin{tabular}{ccccc}
\hline GERAL & $\mathbf{1}^{\mathbf{0}}$ Quartil & $\mathbf{2}^{\mathbf{0}}$ Quartil & $\mathbf{3}^{\mathbf{0}}$ Quartil & $\mathbf{4}^{\mathbf{0}}$ Quartil \\
\hline $\mathbf{- 0 , 1 2 7}$ & 0,543 & 0,243 & 0,207 & $-0,749$ \\
$(\mathbf{0 , 1 3})$ & $(0,00)$ & $(0,16)$ & $(0,23)$ & $(0,00)$ \\
& $* * *$ & & $* * *$ \\
\hline$* \mathrm{p}<0,1 ; * * \mathrm{p}<0,05 ; * * * \mathrm{p}<0,01$ & & & \\
\end{tabular}

Fonte: TSE

Já no interior, o cenário torna-se mais semelhante ao pleito de 2006. É curioso notar, porém, que o PT mantém parte do apoio entre as localidades menos desenvolvidas obtido no pleito anterior. O PSDB também, quando analisadas as localidades em conjunto, apresenta uma ligeira relação negativa entre seu desempenho e o nível de desenvolvimento local. De qualquer maneira, o desempenho do partido 
tucano é elevado em todas as localidades analisadas, sendo em muito superior ao adversário petista.

Gráfico 23 - Percentual de Votos Válidos x Escolaridade Média das Zonas Eleitorais / Municípios (Interior) - $1^{\circ}$ Turno 2014 - PSDB e PT

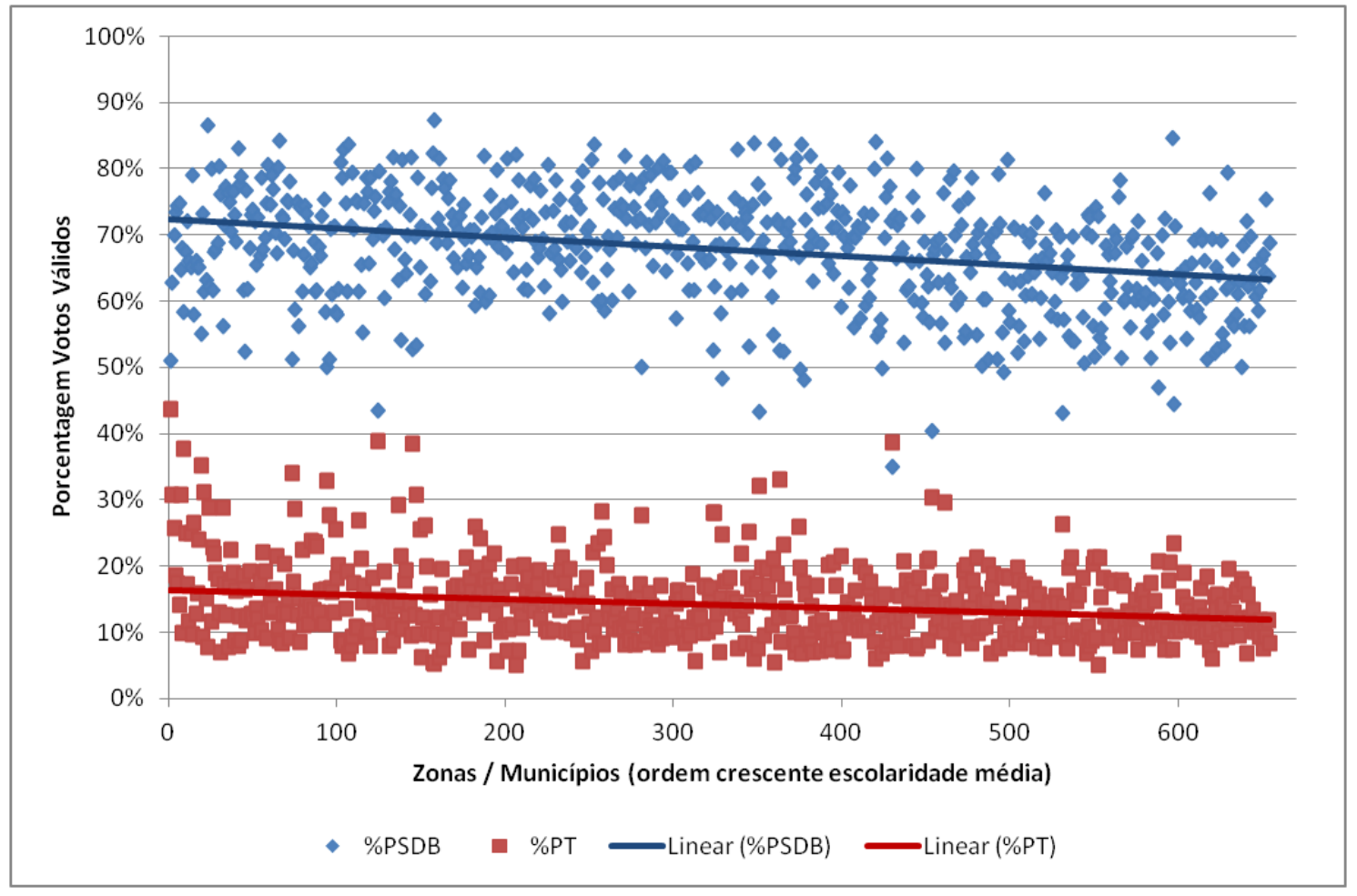

Fonte: TSE 
Quadro 51 - Correlações (R de Pearson) entre percentual de votos válidos e Escolaridade Média das Zonas Eleitorais / Municípios (Interior) - $1^{\circ}$ Turno 2014 PSDB e PT

\begin{tabular}{cccccc}
\hline PARTIDO & GERAL & $\mathbf{1}^{\mathbf{0}}$ Quartil & $\mathbf{2}^{\mathbf{0}}$ Quartil & $\mathbf{3}^{\mathbf{0}}$ Quartil & $\mathbf{4}^{\mathbf{0}}$ Quartil \\
\hline \multirow{2}{*}{ PSDB } & $-0,280$ & 0,133 & 0,05 & $-0,176$ & 0,037 \\
& $(0,0)$ & $(0,08)$ & $(0,52)$ & $(0,02)$ & $(0,63)$ \\
& $* * *$ & $*$ & & $* *$ & \\
& $-0,236$ & $-0,332$ & $-0,137$ & $-0,031$ & $-0,141$ \\
PT & $(0,0)$ & $(0,00)$ & $(0,07)$ & $(0,68)$ & $(0,07)$ \\
& $* * *$ & $* * *$ & $* *$ & & $*$ \\
\hline$* 0<0,1 ; * * 00,0 * * 0<0,01$ & & & &
\end{tabular}

Fonte: TSE

No caso de Skaf (PMDB), sua votação possui relação crescente em relação ao nível de escolaridade média das localidades. Nos testes de correlação, é possível perceber que é sobretudo no primeiro e terceiro quartis que esta relação torna-se mais acentuada.

Gráfico 24 - Percentual de Votos Válidos x Escolaridade Média das Zonas Eleitorais / Municípios (Interior) - $1^{\circ}$ Turno 2014 - PMDB

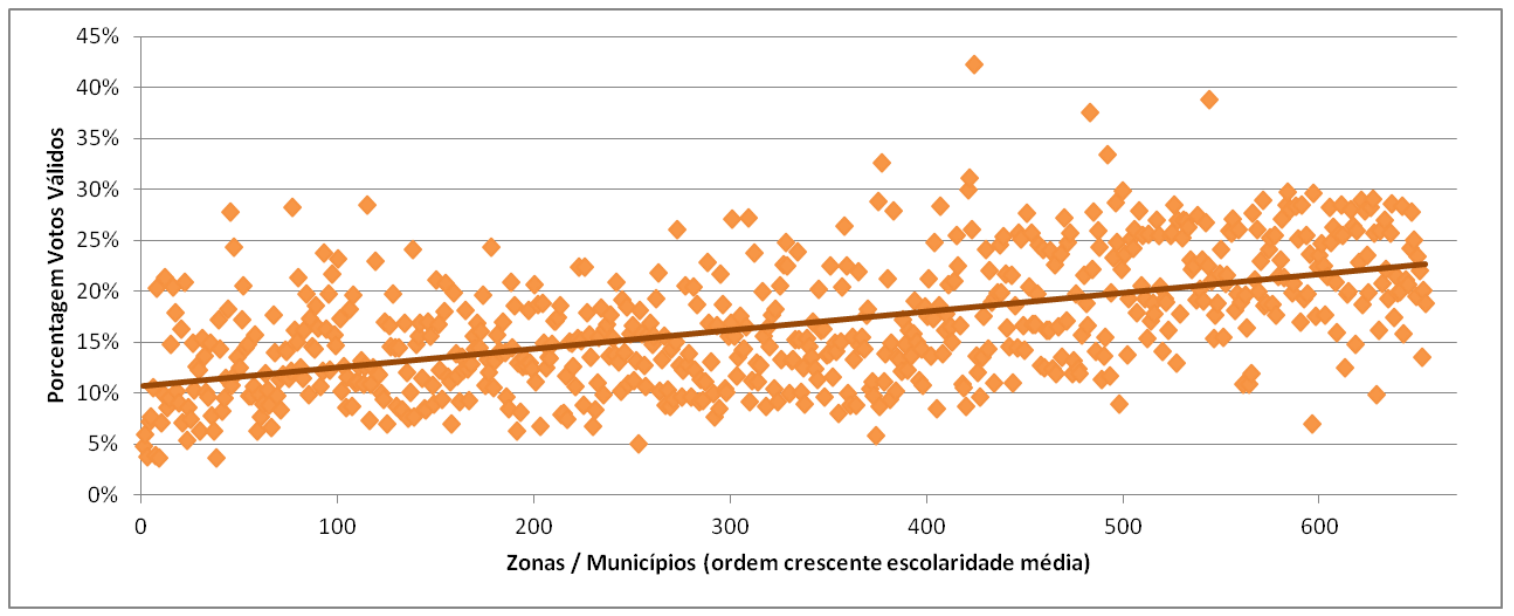

Fonte: TSE 
Quadro 52 - Correlações ( $R$ de Pearson) entre percentual de votos válidos e Escolaridade Média das Zonas Eleitorais / Municípios (Interior) - $1^{\circ}$ Turno 2014 PMDB

\begin{tabular}{ccccc}
\hline GERAL & $\mathbf{1}^{\mathbf{0}}$ Quartil & $\mathbf{2}^{\mathbf{0}}$ Quartil & $\mathbf{3}^{\mathbf{0}}$ Quartil & $\mathbf{4}^{\mathbf{0}}$ Quartil \\
\hline $\mathbf{0 , 5 0 8}$ & 0,271 & 0,072 & 0,267 & $-0,02$ \\
$(\mathbf{0 , 0 )}$ & $(0,00)$ & $(0,35)$ & $(0,00)$ & $(0,75)$ \\
$* * *$ & $* * *$ & & $*$ & \\
\hline$* \mathrm{p}<0,1 ; * * \mathrm{p}<0,05 ; * * * \mathrm{p}<0,01$ & & &
\end{tabular}

Fonte: TSE

\section{Sintese}

No capítulo anterior, procuramos verificar a pertinência da hipótese de que o realinhamento eleitoral ocorrido em bases nacionais em 2006 também teria ocorrido no Estado de São Paulo nas eleições para governador. A partir de dados de pesquisas eleitorais estratificados por escolaridade e renda (bem como a divisão de municípios e zonas eleitorais pelo nível médio de escolaridade - mecanismo metodológico para identificação do nível de desenvolvimento médio dessas localidades), identificamos que este fenômeno ocorreu em termos nestes pleitos: é fato que o apoio ao PSDB é crescente à medida em que se avançam nos índices de escolaridade e renda do eleitorado. Por outro lado, o partido tucano sai de um patamar elevado de preferências entre os eleitores dos estratos de menor escolaridade e renda. Nas eleições de 2014, ademais, os dados apresentados demonstravam maior apoio ao candidato tucano nos locais e estratos de escolaridade e renda menores.

Neste segundo capítulo, procuramos avançar na compreensão deste achado a partir da análise dos componentes territoriais das eleições estaduais. Primeiramente, procuramos identificar se há diferenças de base de apoio aos principais partidos quando se leva em conta o tamanho dos municípios; em seguida, observamos a distribuição de votos ao longo do território paulista levando em conta aspectos regionais e nível de desenvolvimento médio do eleitorado. Esta observação foi efetuada a partir da divisão do Estado de São Paulo em duas unidades pré-estabelecidas que, a despeito de possuírem distribuição populacional semelhante, contam com diferenças importantes do ponto de vista sociodemográfico: o interior e a Grande São Paulo. Para cada uma dessas 
unidades, efetuamos testes de correlação e apresentamos o padrão de distribuição de votos em ordem crescente de escolaridade média das zonas eleitorais e dos municípios.

Em relação ao tamanho dos municípios, a partir de análise dos resultados eleitorais desde 1994 observamos que progressivamente o apoio ao PSDB é negativamente correlacionado em relação ao número de habitantes das cidades paulistas. Interpretamos este fenômeno como uma "substituição" do então partido predominante no interior do Estado (local que concentra os menores municípios), o PMDB (SADEK, op. cit.). Este, por sua vez, após longo processo de decadência eleitoral nos anos 1990 e 2000, teve na última eleição uma candidatura competitiva (segunda colocação) e que inverteu o padrão histórico do partido nos anos 1990: há correlação positiva moderada entre a votação de Paulo Skaf (PMDB) e o tamanho dos municípios paulistas (ou seja, maior apoio nas cidades mais densamente povoadas do Estado).

Já o PT apresenta movimento diferente em relação ao do PSDB em termos de bases sociais municipais. Nos anos 1990, o partido apresentava correlações positivas acima de 0,5 em relação ao tamanho dos municípios, em consonância com sua penetração mais expressiva nas regiões metropolitanas e em maiores cidades do Estado. Nos anos 2000, tais coeficientes diminuem a tal ponto de tornarem-se inexpressivos na eleição de 2010. Em 2014, há uma fraca correlação positiva entre o voto no partido e o tamanho dos municípios. Ainda assim, os dados revelam que, ao encontro das hipóteses de Andreza Davidian (2013), o PT aumenta sua penetração ao longo do tempo no Estado de São Paulo e torna-se menos “dependente” das regiões mais populosas.

Por fim, o PDS/PP também sofre uma inflexão no período recente. Se nas eleições de 1998 e 2002 o partido apresentava uma fraca correlação com relação ao tamanho dos municípios (o que denotava a ampla penetração do então candidato Paulo Maluf em todo o território estadual), no último pleito em que apresentou candidato (2010) o PDS/PP teve correlação moderada significativa positiva em relação ao tamanho dos municípios. Tal fato está provavelmente relacionado com o perfil de seu candidato de então, Celso Russomano, que construiu sua carreira política na Grande São Paulo - sendo inclusive candidato a prefeito dos municípios de Santo André (2000) e São Paulo (2012). 
Em termos da distribuição dos votos, encontramos um panorama muito distinto de votação entre os partidos ao longo dos pleitos em termos de localidade (interior ou Grande São Paulo) e nível de desenvolvimento.

Na Grande São Paulo, até 2002 prevalecia uma distribuição relativamente homogênea de votos entre os dois principais partidos, PT e PSDB, em relação ao nível de desenvolvimento das localidades. Quando olhados de maneira seccionada, porém, os dados apresentam pequenas diferenças entre ambos. Em relação ao PSDB, sua curva de distribuição de votos é maior nos extremos inferior e superior, com - respectivamente diminuição e aumento das preferências na medida em que se avançam os níveis de escolaridade média do eleitorado. Para o PT, o perfil é inverso: o partido possuía maior apoio nas duas camadas médias das regiões, com dificuldades crescentes à medida em que aumentavam ou diminuíam os níveis de escolaridade média dos eleitores nas localidades.

No interior, há uma distribuição mais homogênea de votos para o PSDB, ao passo que o PT possui correlação moderadamente positiva à medida em que avançam os níveis de escolaridade média do eleitorado. Nota-se, assim, uma diferença entre as duas unidades de análise (interior e Grande São Paulo), ainda que os dados agregados encontrados se coadunem com o apontado pela literatura (a saber, o perfil predominante de "classe média" do eleitorado de ambos os partidos ${ }^{51}$ ).

A eleição de 2006, considerada paradigmática em termos nacionais, também tem inflexões importantes no pleito estadual. Na Grande São Paulo, tornam-se mais relevantes as diferenças de bases sociais entre PT e PSDB - sobretudo no último quartil em termos de desenvolvimento. O apoio dos segmentos mais elitizados ao partido tucano torna-se ainda maior, pari passu ao aumento da rejeição ao PT neste mesmo eleitorado. As curvas de distribuição de preferências passam a contar com correlações significativas e opostas para ambos os partidos, em consonância com o padrão encontrado em pleitos nacionais (ainda que em menor magnitude).

\footnotetext{
${ }^{51}$ Vale lembrar que, em 2000, ocorreu a "onda rosa" nas eleições municipais brasileiras, quando o PT conquistou 186 prefeituras em todo o Brasil (sendo 6 capitais), aumento de 69\% em relação a 1996 (Folha de São Paulo, 04 de outubro de 2000). Em São Paulo, a vitória mais importante foi na capital. O partido venceu também em outras grandes cidades paulistas, casos de Campinas, Ribeirão Preto, Araraquara, Santo André, Diadema, São Carlos, entre outras.
} 
Em relação aos municípios do interior, porém - e este é o principal elemento a ser destacado neste capítulo - é homogêneo o padrão de distribuição de votos entre PT e PSDB em termos de escolaridade média do eleitorado. O predomínio do PSDB é extensível a todas as zonas eleitorais e municípios, com distância considerável em relação a seu principal oponente. O padrão "lulista" das eleições nacionais (de maneira simplista, localidades mais pobres com o PT, mais desenvolvidas com o PSDB) ocorreu, sim, nas eleições estaduais paulistas; porém apenas na região metropolitana da capital. Prevaleceu, no interior do Estado, o amplo predomínio do PSDB nos diferentes segmentos do eleitorado ${ }^{52}$.

Em 2010, o padrão de distribuição de votos no Estado de São Paulo aproxima-se do padrão nacional: na região metropolitana da Grande São Paulo, tornam-se ainda mais fortes as correlações entre nível de desenvolvimento das localidades e voto nos principais partidos. No quartil de desenvolvimento mais elevado, é praticamente linear a relação inversa de apoio entre PSDB e PT.

Mesmo no interior, o padrão torna-se um pouco menos homogêneo. Há correlação negativa - fraca, porém significativa estatisticamente- entre o nível médio de escolaridade e a votação do PT (sobretudo no primeiro e no último quartil). O PSDB, porém, permanece com a distribuição praticamente homogênea em sua distribuição de preferências. Ou seja, o partido obtinha votos de maneira relativamente semelhante em todas as localidades no interior do Estado, não importando o nível de desenvolvimento das mesmas.

Em 2014, este cenário torna-se menos polarizado. Na Grande São Paulo, ampliase o predomínio do PSDB em todas as faixas do eleitorado, ainda que permaneça a correlação positiva e negativa com o nível de desenvolvimento em termos de votação de PSDB e PT, respectivamente. A reentrada do PMDB na disputa é acompanhada de um perfil de votação semelhante ao do PT pré-2006 (ou seja, com maior preponderância na classe média). Paulo Skaf possui seus piores índices entre os eleitores do primeiro e do último quartil de distribuição de escolaridade média (ambos os terrenos ocupados pelos seus principais adversários).

\footnotetext{
${ }^{52}$ Ademais, o PT perdeu seu apoio crescente nos locais mais desenvolvidos no interior - nesse caso, em consonância com os padrões nacionais de votação do partido.
} 
No interior, poderia se dizer que há uma tendência à inversão de bases na preferência dos eleitores em termos semelhantes ao padrão nacional - os protagonistas e papeis, porém, são em muito distintos. Por um lado, há uma pequena correlação negativa entre o voto no PSDB e o nível de desenvolvimento médio das localidades. Por outro, há correlação expressiva e inversa para o PMDB neste mesmo conjunto de localidades. Assim, é seguro dizer que, tanto na Grande São Paulo quanto no interior, foi entre os segmentos mais populares do eleitorado que Geraldo Alckmin (PSDB) ancorou sua expressiva votação no pleito de 2014.

Resta, porém, uma questão em aberto neste capítulo: a conexão entre a primeira seção (relação voto / tamanho de município) e a segunda (relação voto / local e nível de desenvolvimento).

Com relação ao primeiro aspecto, o amplo predomínio do PSDB no interior do Estado coaduna-se com a correlação negativa crescente do partido em relação ao tamanho dos municípios. Ao se verificar também a importante penetração do partido na região metropolitana da capital, pode-se dizer que o PSDB conseguiu "resolver" a contradição que marcou historicamente os partidos em São Paulo. Com efeito, verificamos no primeiro capítulo que a dicotomia "interior x capital" (ou, anteriormente, rural / urbano) marcou as eleições paulistas ao longo do Regime de 1946, do Regime Militar e dos primeiros pleitos da redemocratização.

O percurso do $\mathrm{PMDB}$, nesse aspecto, é marcante. De então partido urbano e altamente sufragado pelas classes populares durante a Ditadura (ainda como MDB) e no primeiro pleito democrático (1982), o partido passa por processo paulatino de interiorização. O processo, no entanto, não ocorre impunemente: a "sigla mágica" (LAMOUNIER, 1978), o então "partido do povo" (REIS \& CASTRO; 1992), perde sua importante presença nos redutos populares urbanos do Estado de São Paulo.

Neste sentido, a proeza tucana ganha contornos mais relevantes: ao mesmo tempo em que suplantou a "célula mater" peemedebista no interior do Estado, o PSDB conseguiu manter um importante ancoramento na região metropolitana da capital do Estado - amplamente majoritária nos segmentos mais abastados e expressiva entre os segmentos populares. Tal cenário consolida-se gradativamente a cada conquista eleitoral do partido e parecia estar sob princípio de ameaça no pleito de 2010. As eleições de 
2014, porém, retomaram o padrão estabelecido no pleito de $2006^{53}$ : amplo predomínio no interior entre as diferentes faixas do eleitorado e apoio crescente à medida em avançam os níveis de desenvolvimento das localidades na região da capital.

Frisamos uma vez mais que o padrão de votação do PSDB na Grande São Paulo assemelha-se ao encontrado pelo partido em nível nacional (quanto maior o nível de desenvolvimento local, maior a prevalência do partido - ainda que com apoio expressivo já nos locais de menor desenvolvimento). No interior, apoio expressivo e relativamente homogêneo entre todos os segmentos do eleitorado analisados.

Principal adversário do PSDB no Estado, o PT tem performance, em linhas gerais, simétricas e opostas em relação àquele. Até 2002, a presença mais ostensiva do partido nas regiões metropolitanas não o impediu de estabelecer nível considerável e crescente de apoio entre os eleitores de estrato médio do interior paulista. Sua maior dificuldade repousava nos extremos (de maior e menor desenvolvimento) da Grande São Paulo. No pleito seguinte, a seção paulista acompanhou, apenas em termos, o realinhamento eleitoral petista em nível nacional. Houve perda significativa entre os eleitores de nível médio e alto do eleitorado da região da capital, e o partido conseguiu estabelecer apoio maior entre as camadas mais populares no mesmo local. Já no interior, em todos os locais o desempenho petista foi muito aquém do seu adversário, não havendo penetração maior nos locais de maior vulnerabilidade. Tal cenário modifica-se um pouco na eleição seguinte de 2010 (vale lembrar, auge da popularidade da maior liderança do partido, o ex-presidente Lula), que caminha para contornos mais próximos aos encontrados em nível nacional: o partido obtém desempenho expressivo na Grande São Paulo (ancorado nos locais menos desenvolvidos) e passa contar com mais apoio nos segmentos populares do interior. Em 2014, porém, o partido retrocede em termos de desempenho geral e perde, inclusive, a segunda posição estadual para o candidato peemedebista.

Com relação ao PDS/PP, a decadência do malufismo em São Paulo causou sequelas importantes no que outrora fora denominado "o maior partido do Ocidente" A penetração em todo o Estado até 2002 transforma-se, no pleito de 2010, em uma

\footnotetext{
${ }^{53}$ Note-se que, em ambos os pleitos (2006 e 2014), os candidatos tucanos (José Serra e Geraldo Alckmin, respectivamente) obtiveram praticamente o mesmo percentual de votos válidos (cerca de 57\%).

${ }^{54}$ A expressão é de Francelino Pereira para caracterizar a força da agremiação que presidia, a ARENA, partido fundado para sustentação político-institucional do Regime Militar e precursor do PDS/PP. Sobre a ARENA, ver GRIMBERG (2009).
} 
candidatura ancorada na região metropolitana da capital, sobretudo nos locais de menor nível de desenvolvimento. Vale lembrar que o candidato pepista em 2010 foi Celso Russomano, que em 2012 (já no PRB) lançaria-se candidato à prefeitura de São Paulo com penetração importante nas franjas da cidade. Assim, se ao partido restou o papel de coadjuvante no percurso eleitoral recente, não se deve negligenciar a importância presença de um eleitorado conservador e popular no eleitorado urbano paulista.

Por fim, o PMDB. Como já mencionamos, há um contínuo processo de decadência eleitoral do partido ao longo dos anos 1990 e 2000 (BIZARRO, 2013). Nas eleições de 2014, porém, o partido volta a lançar um candidato competitivo e com novidades em termos de perfil social de votação. Conforme vimos no capítulo anterior, Paulo Skaf obtinha crescentes preferências dos eleitores entrevistados à medida em que avançavam os níveis de escolaridade e renda. Este perfil vai ao encontro do que observamos neste capítulo, ao menos com relação ao interior do Estado (onde o apoio a Skaf cresce em consonância com o aumento da escolaridade média do eleitorado ${ }^{55}$ ). $\mathrm{Na}$ Grande São Paulo, os votos peemedebistas concentraram-se nos setores médios, sendo que Skaf teve maiores dificuldades nos setores mais e menos desenvolvidas da metrópole.

\footnotetext{
${ }^{55}$ Como vimos na primeira seção, o voto em Skaf é positivamente correlacionado com o tamanho populacional dos municípios. No quadro 30 , identificamos que o candidato peemedebista teve sua melhor votação no grupo de municípios entre 100 e 500 mil habitantes. A hipótese aqui é que o apoio ao candidato deu-se sobremaneira entre os setores de médio e de alto padrão de vida de grandes cidades do interior. De fato, o candidato peemedebista obteve percentuais de votação superiores à sua média geral (21,53\%) em municípios como Campinas (24,65\%), Sorocaba (27,23\%), Ribeirão Preto (24,94\%), Bauru $(28,12 \%)$, Franca $(25,38 \%)$ e Araraquara $(29,2 \%)$. Fonte: Fundação SEADE.
} 


\section{Capítulo 4 - Considerações Finais}

Nesta dissertação, procuramos investigar o fenômeno do amplo predomínio do PSDB no Estado de São Paulo nas eleições para governador. A partir da análise dos resultados eleitorais dos seis pleitos (entre 1994 e 2014) em que o PSDB saiu-se vencedor, analisamos as características do eleitorado do partido em torno de três aspectos: o perfil socioeconômico do eleitorado, os índices de votação em relação ao tamanho dos municípios paulistas e os padrões de votação em relação a duas unidades geográficas pré-estabelecidas (a Grande São Paulo e o interior) conjugadas com índice de desenvolvimento médio das localidades eleitorais (zonas eleitorais e municípios). A ênfase das análises foi colocada nas eleições após 2002. Neste pleito, o PSDB perdeu a presidência da República para seu principal rival, o PT (partido que pela primeira vez conseguira chegar ao poder central), fato que teve impactos significativos no panorama partidário e eleitoral brasileiro. Conforme apontamos no capítulo 2, a literatura dá destacada importância ao pleito de 2006, tendo em vista as modificações ocorridas na base social do voto presidencial no PT (que passou a concentrar-se nos segmentos de menor renda do eleitorado) e no PSDB (cuja presença se acentua nos estratos de maior nível socioeconômico da população).

Procuramos, assim, verificar se esta estratificação de bases sociais teria ocorrido também em um contexto subnacional. A partir, sobretudo, de dados de pesquisas eleitorais estratificados por escolaridade e renda, verificamos que, em São Paulo, o realinhamento eleitoral ocorrido em nível nacional teve características diversas. As bases sociais brasileiras características do PSDB mantiveram-se (eleitorado de maior escolaridade e renda). A recíproca em relação ao PT, porém, não foi verdadeira: os tucanos conseguiram manter um amplo apoio mesmo entre os segmentos mais pobres do eleitorado.

Assim, a hipótese inicial deste trabalho pôde ser demonstrada parcialmente. Como esperado, encontramos um amplo predomínio do PSDB entre os eleitores de maior nível socioeconômico. Por outro lado, a penetração do partido nos estratos mais populares do Estado de São Paulo é, ainda que menor, muito significativa. Deste modo, pode-se dizer que os tucanos lograram, no Estado de São Paulo, manter seu predomínio para além de suas tradicionais bases de apoio - sendo capazes, assim, de "conter" o processo de realinhamento eleitoral ocorrido a partir do pleito de 2006 em nível nacional. Em outras palavras, por um lado o PSDB consolidou seu expressivo apoio 
entre os segmentos médios e altos do eleitorado. Por outro, manteve (de forma inesperada, de acordo com a literatura) um importante suporte entre o eleitorado paulista de menor poder aquisitivo.

Este panorama parecia apresentar tendências de modificação no pleito de 2010, quando o candidato do PSDB teve desempenho menos expressivo entre os segmentos populares do eleitorado. Nesta eleição, mesmo derrotado, o PT obteve, nas eleições para o governo estadual, sua melhor performance na história, tendo obtido o voto de mais de um terço dos eleitores. Havia indícios, assim, de um processo de alinhamento eleitoral paulista com o âmbito nacional.

Nas eleições de 2014, porém, a votação do PSDB teve colorações "lulistas": o candidato Geraldo Alckmin obteve suporte mais expressivo entre os segmentos mais populares do eleitorado do que entre as camadas mais abastadas. Este cenário é de grande relevância para o campo dos estudos eleitorais, na medida em que aponta para duas tendências na relação entre os partidos e suas bases sociais: por um lado, a perda de base social do PT entre as camadas de menor poder aquisitivo, esteio do processo que Singer (2012) denominou de lulismo. De outro, a entrada de um concorrente do PSDB nos segmentos de médio e alto poder aquisitivo da população - foi entre estes eleitores que Paulo Skaf (PMDB) obteve maior apoio ${ }^{56}$. Conforme ressaltamos, tratamse apenas de conjecturas baseadas no último pleito; apenas os resultados futuros das urnas e novas pesquisas empíricas poderão revelar se tais cenários se concretizarão.

Conforme vimos nos capítulos 1 e 3, a literatura em estudos eleitorais referentes ao Estado de São Paulo aponta as diferenças regionais e a magnitude populacional dos municípios como variáveis importantes para identificação de bases sociais dos principais partidos. A distinção entre pequenos e grandes municípios e a localização dos mesmos no território paulista (se mais próximos ou mais distantes, por exemplo, da capital paulista) foram elementos importantes de diferenciação dos principais partidos em disputa. Assim, a dinâmica de voto no Estado apresentou, ao longo do tempo, clivagens regionais e demográficas claramente identificáveis (MENEGHELLO \& BIZARRO, 2012).

\footnotetext{
${ }^{56}$ Vale lembrar que Skaf já havia sido candidato por outro partido em 2010 (o PSB), com desempenho pouco expressivo (obteve menos de 5\% dos votos válidos). Assim, ainda não está claro se o desempenho é atribuído mais ao "recall" do candidato ou, de fato, a uma reentrada do PMDB na disputa partidária paulista.
} 
Ao utilizarmos estas duas variáveis - a saber, tamanho do município e localização eleitoral (interior ou Grande São Paulo), verificamos que o PSDB possui apoio crescente à medida em que diminui a magnitude populacional dos municípios. Neste sentido, interpretamos tal fenômeno como a sucessão do processo que Sadek (1987) denominou de "interiorização" do PMDB. Após suceder sua sigla originária em 1994, o PSDB tornou-se paulatinamente predominante nas localidades menores e mais afastadas da capital do Estado, locais esses onde obtém seu melhor desempenho eleitoral. Destacamos, porém, que tal apoio não se deu em detrimento ao suporte ao partido nos maiores municípios, dado que o partido tucano também obtém votações expressivas (ainda que um pouco menores) nas cidades densamente povoadas do Estado.

Em seguida, efetuamos uma divisão entre duas regiões de magnitude populacional semelhante, mas com diferenças sociais e políticas importantes: o interior do Estado e a região metropolitana da Grande São Paulo. A partir de dados de escolaridade média das zonas eleitorais e dos municípios (indicador utilizado como proxy do nível de desenvolvimento local), elaboramos uma escala de votação dos partidos. O intuito era verificar se havia diferenças significativas no desempenho das principais agremiações à medida em que se elevava ou se diminuía o padrão de desenvolvimento local no interior e na Grande São Paulo.

Verificamos que, em relação ao interior do Estado, o predomínio do PSDB é prevalente em relação a todos os locais - ou seja, não há diferenças significativas de apoio ao partido à medida em que avançam ou retrocedem os padrões de desenvolvimento locais. Na Grande São Paulo, todavia, identificamos um padrão mais próximo ao encontrado em nível nacional (também para o PT): o apoio ao PSDB é crescente à medida em que avançam os níveis de desenvolvimento locais, sendo inverso o perfil do PT. Assim, podemos afirmar que o incipiente realinhamento eleitoral ocorrido no Estado de São Paulo a partir de 2006 é fenômeno sobretudo urbano, localizado na região metropolitana da capital paulista. No interior do Estado, os resultados apresentados nesta pesquisa indicam uma prevalência homogênea do PSDB entre todos os segmentos do eleitorado.

Desse modo e para fins de recapitulação, as principais conclusões desta pesquisa, em termos de resultados, poderiam ser resumidas na seguinte forma: nas 
eleições para o governo do Estado entre 1994 e 2014 em São Paulo, o PSDB obtém um importante suporte entre os estratos populares do eleitorado. Tal perfil se mantém mesmo após 2006, quando a base social de sustentação eleitoral do partido em nível nacional torna-se mais identificada com eleitorado de estratos socioeconômicos mais elevados. O partido mantém seu predomínio nesta faixa do eleitorado no Estado de São Paulo, mas não tem perdas elevadas de bases sociais entre os eleitores de menores condições socioeconômicas.

Em termos demográficos, o desempenho do partido é mais significativo nos municípios menores, fato que aponta para sua presença marcante no interior do Estado. Nesse, o amplo predomínio do PSDB é homogêneo em todas as localidades analisadas (menos e mais desenvolvidas). Na Grande São Paulo, porém, encontra-se um padrão de distribuição de preferências mais semelhante ao encontrado em nível nacional - ou seja, com o partido tucano tendo votações menores nos locais menos desenvolvidos. Assim, pode-se inferir que o realinhamento eleitoral, no Estado de São Paulo tem características sobremaneira urbanas. A prevalência do PSDB no interior (demonstrada pela sua penetração nos pequenos municípios) se mostrou de maneira homogênea nas diferentes localidades.

Estamos cientes de que tais achados são parciais e não levam em conta outros elementos que poderiam ser acionados para estudo de fenômeno tão complexo. Neste sentido, as recomendações de Vilmar Faria (1974; p.210) - que realizou estudo semelhante nos anos 1970 para o Estado de São Paulo em relação ao MDB e à ARENA - merecem especial atenção e permanecem válidas: a inserção de novas variáveis explicativas ou a observação a partir de outras abordagens teóricas e metodológicas podem trazer novos elementos para a compreensão desse importante fenômeno da política brasileira. Para fins de prospecção, levantaremos algumas hipóteses e abordagens complementares que poderão ser desenvolvidas em pesquisas futuras.

Em termos partidários, verificamos no panorama eleitoral paulista desde 1982 a paulatina decadência do PMDB e do PDS/PP ao longo das décadas de 1980 e 1990. Com efeito, a "sigla mágica" peemedebista e o "malufismo" (rival tanto do PT quando do PSDB em eleições na capital e no Estado ao longo do período) perderam o 
protagonismo eleitoral e tornaram-se coadjuvantes na disputa ${ }^{57}$ - situação essa que se modificou no pleito de 2014, quando o PMDB voltou a ocupar a segunda colocação. Conforme já mencionado, a dissidência do PSDB em relação ao PMDB pode ter causado estragos tanto do ponto de vista eleitoral (pela ocupação do espectro ideológico) quanto organizacional (pela migração de lideranças, militantes e diretórios). Em outras palavras, o PSDB teria suplantado seu partido de origem em diferentes $\operatorname{aspectos}^{58}$.

\section{Gráfico 25 - Votos Válidos dos Partidos - Eleições para Governador de São Paulo (1982-2014) - 10 Turno}

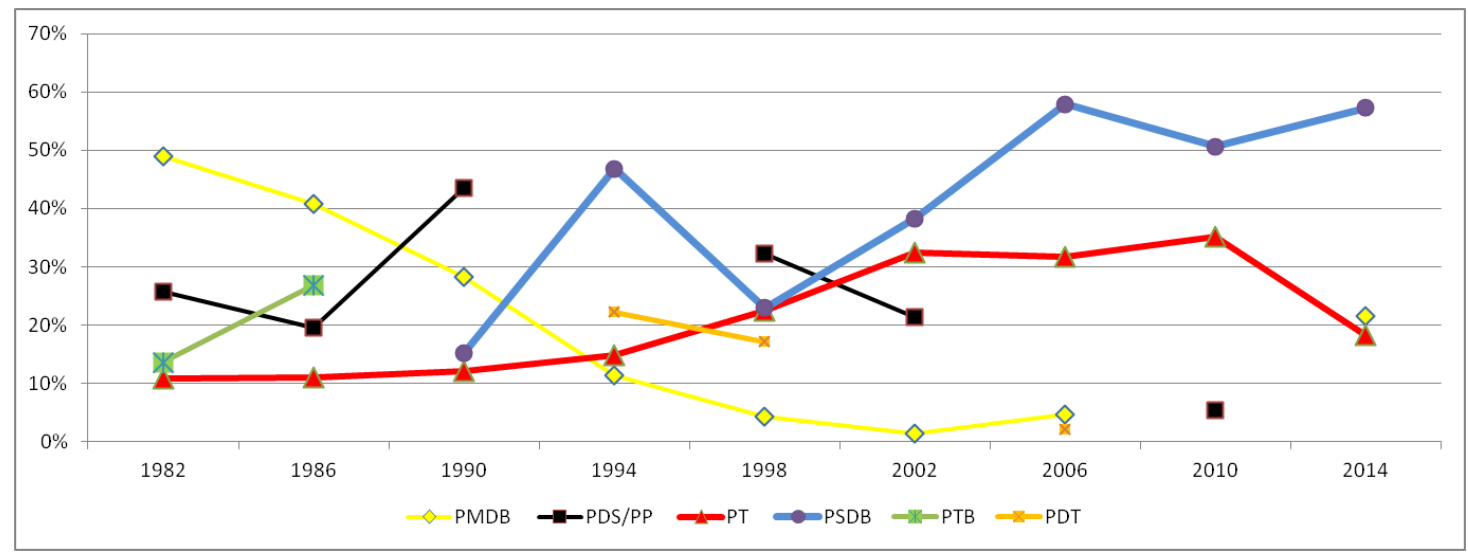

Fonte: TSE

A observação das alianças e coligações ao longo dos últimos trinta anos também parece apontar para a progressiva consolidação de blocos partidários distribuídos em torno dos dois principais competidores, PT e PSDB, até 2010. No Anexo III inserimos um diagrama de coligações no Estado, pelo qual é possível observar que o cenário de fragmentação dos pleitos ao longo dos anos 1990 torna-se mais "concentrado" ao longo da década de 2000. Determinados partidos de relevo nos anos 1980 (caso do PTB) e

\footnotetext{
${ }^{57}$ Foge ao escopo deste trabalho a análise da decadência de ambos os partidos. Apenas a título de hipótese, lembramos que ambos foram controlados por lideranças de grande vulto, Orestes Quércia (PMDB) e Paulo Maluf (PDS/PP) - que praticamente monopolizaram as candidaturas e o controle das estratégias eleitorais e partidárias destas agremiações no período recente. Há uma ampla corrente de estudos em ciência política acerca da tendência de oligarquização de partidos e insulamento de lideranças partidárias - o que poderia chocar-se até mesmo com a própria capacidade de renovação e sobrevivência política do partido. Ver, a este respeito, MICHELS (1982) e WEBER (2011). Para uma análise da trajetória recente do PMDB paulista e o papel exercido por Orestes Quércia, ver BIZARRO NETO (2013).

${ }^{58}$ Meneghello \& Bizarro (op. cit.) corroboram esta hipótese ao analisar a migração partidária no período 1986-1996. De acordo com os dados coletados pelos autores, o PSDB é o partido que mais absorve candidaturas de quadros originados no PMDB.
} 
1990 (PDT) abrem mão de participar da disputa majoritária e coligam-se com os outrora adversários.

Neste sentido, a decadência destes partidos parece ter aberto um espaço considerável no campo da "centro-direita" no contexto de bipolarização eleitoral. O quadro abaixo apresenta as votações dos primeiros colocados de cada eleição desde 1990, quando houve o segundo turno pela primeira vez. Observa-se que em todos os pleitos até 2002 houve segundo turno, e a votação somada dos dois primeiros colocados chegou, no máximo, a 70\% do total de votos válidos. Nos pleitos de 2006 e 2010 quando a votação somada de ambos os candidatos atingiu quase $90 \%$ do total de votos esperadamente não houve a segunda rodada eleitoral. Em 2014, a candidatura de Skaf (oriunda de coligação entre PMDB, PDS/PP e o PSD - dissidência do DEM/PFL) trouxe novamente à disputa um polo para além de PT e PSDB. Ainda assim, não conseguiu romper com o amplo predomínio do partido tucano. Não resta claro, porém, se o PMDB será capaz de constituir-se efetivamente como segunda força no Estado de São Paulo - posição ocupada pelo PT até então. A hipótese, portanto, é de que o PSDB teria absorvido o "espólio" de partidos que outrora ocupavam o campo da direita, da centro-direita e do centro no Estado de São Paulo, tornando-se a única alternativa viável para eleitores desse espectro ideológico nas eleições para o governo do paulista ${ }^{59}$.

\section{Quadro 53 - Votação Somada dos Dois Primeiros Colocados no Primeiro Turno em SP (1990-2014)}

\begin{tabular}{|c|c|c|c|c|}
\hline \multirow{2}{*}{ Eleição } & \multirow{2}{*}{$\%$} & \multicolumn{2}{|c|}{ Primeiras posições } & \multirow{2}{*}{$\begin{array}{c}2^{\mathbf{o}} \\
\text { Turno? }\end{array}$} \\
\hline & & $\mathbf{1}^{\mathbf{0}}$ & $2^{\mathbf{o}}$ & \\
\hline 1990 & $71,68 \%$ & $\mathrm{PDS} / \mathrm{PP}$ & PMDB & SIM \\
\hline 1994 & $69,07 \%$ & PSDB & PDT & SIM \\
\hline 1998 & $55,16 \%$ & $\mathrm{PDS} / \mathrm{PP}$ & PSDB & SIM \\
\hline 2002 & $70,72 \%$ & PSDB & PT & SIM \\
\hline 2006 & $89,60 \%$ & PSDB & $\mathrm{PT}$ & NÃO \\
\hline 2010 & $85,86 \%$ & PSDB & $\mathrm{PT}$ & NÃO \\
\hline 2014 & $78,84 \%$ & PSDB & PMDB & $\mathrm{NÃO}$ \\
\hline
\end{tabular}

Fonte: TSE

\footnotetext{
${ }^{59}$ Não possuímos pesquisas recentes referentes a classificação ideológica no Estado de São Paulo. Em nível nacional, pesquisa do Instituto Datafolha realizada em setembro de 2014 apontou que $45 \%$ dos eleitores mostravam-se afinados com ideias vinculadas à direita, $35 \%$ à esquerda e $20 \%$ ao centro. É esperado que a distribuição no Estado paulista seja distinta, mas acreditamos que a tendência seja a presença também de um bloco majoritário ao centro e à direita.

Fonte: $\quad$ http://datafolha.folha.uol.com.br/eleicoes/2014/09/1512693-direita-supera-esquerda-nobrasil.shtml (acesso em 14 de Novembro de 2015).
} 
Outra questão relevante é a prevalência de líderes de destaque do PSDB nas eleições em São Paulo ${ }^{60}$. Se consideradas as eleições da cidade de São Paulo (dado o peso político da capital), o partido tucano contou com a mesma tríade de candidatos desde 1988 (ano de sua fundação): Mario Covas, Geraldo Alckmin e José Serra ${ }^{61}$. Destaque-se ainda que os três foram candidatos a presidente da República, fator este que não deve ser desprezado - ainda que de difícil mensuração - para a sedimentação do conhecimento e da preferência dos eleitores. Limongi e Mesquita (2008), por exemplo, apontam que a recorrência de Paulo Maluf (PDS/PP) nas candidaturas a cargos executivos (Estado e capital) ao longo dos anos 1980 e 1990 não seria apenas um vezo de personalidade obstinada do candidato, mas sim uma estratégia coerente de ocupação de campo político-eleitoral. Não seria esta, de modo análogo, a estratégia dos principais quadros do PSDB ao se lançarem continuamente como candidatos (frise-se: os mesmos quadros $^{62}$ ) em todas as eleições do período?

Outro aspecto a ser considerado é a influência da polarização nacional na configuração eleitoral do Estado, se compreendida na chave institucionalorganizacional $^{63}$. Por um lado, a polarização entre PSDB e PT parece ter consolidado, ao menos até 2010, um campo de disputa no Estado de São Paulo, fato este que torna considerável o custo de entrada na competição para novos atores. A ascensão do PMDB no pleito de 2014, conforme mencionamos acima, merece ser observada com atenção nos futuros pleitos.

Deve-se levar em conta também a relevância do controle do governo no processo eleitoral - elemento que não pode ser desconsiderado quando analisamos uma hegemonia eleitoral de duas décadas e a prevalência expressiva do partido governista (PSDB) nas pequenas municipalidades. Nos anos 1990, Fernando Abrucio (1998) apontou a preponderância dos governadores na mediação entre a política nacional e as localidades regionais. Denominados pelo autor de "barões da Federação", os governadores seriam atores de maior relevância no panorama institucional brasileiro da Nova República, status esse mantido após a promulgação da Constituição de 1988.

\footnotetext{
${ }^{60}$ Poderia se dizer, utilizando a classificação adotada por Duverger (1980), que esta trajetória coaduna-se com a definição clássica de um partido de quadros.

${ }^{61}$ Exceto na campanha paulistana de 1992, quando o candidato foi Fabio Feldmann.

${ }^{62}$ No anexo II deste trabalho apresentamos a lista de candidatos dos principais partidos (PSDB, PT, PMBD e PDS/PP) nas eleições paulistas e paulistanas desde 1982. Optamos pela inserção da capital no quadro dada sua importância político-eleitoral para o conjunto do Estado.

${ }^{63}$ Ver LIMONGI \&CORTEZ (2010) e LIMONGI \& GUARNIERI (2014).
} 
A literatura mais recente, porém, aponta a consolidação de um modelo de federalismo no qual a relação entre a União e os municípios em diferentes áreas de políticas públicas prescinde da mediação estadual. Ademais, a própria consolidação de políticas sociais diretas de caráter universalista por parte da União (ou seja, sem a necessidade de autorização e tutela dos governos locais) tenderia a "quebrar" os mecanismos de poder regionais (ARRETCHE, 2000).

Do ponto de vista partidário e eleitoral, tal reconfiguração teria impactos profundos. Por um lado, atuariam para quebrar a "espinha dorsal" de partidos historicamente arraigados em regiões em que o peso das máquinas políticas foi preponderante. Este é o caso, por exemplo, do PFL/DEM. Sua migração para a oposição em nível federal a partir de 2002 significou um duro golpe em seu bastião mais importante, o Nordeste brasileiro. Aos poucos, um dos principais partidos brasileiros tornou-se coadjuvante na região em que outrora obtinha sua melhor performance (RIBEIRO, 2011).

André Borges (2010) resume a questão da seguinte maneira:

"Por conta dessas mudanças, é de esperar-se que haja uma menor dependência dos eleitores pobres frente à intermediação política realizada pelas elites estaduais. O que nos leva a inferir (...) que a decadência das máquinas políticas outrora dominantes nos estados mais pobres e de menor competitividade eleitoral da federação é um processo de natureza estrutural e não apenas conjuntural. De um lado, o federalismo e as instituições eleitorais e partidárias da democracia brasileira conspiram contra a reprodução de oligopólios eleitorais na esfera dos estados. De outro, o próprio processo de competição democrática (...) contribui para erodir as bases da intermediação clientelista nas regiões mais pobres. Em outras palavras, a trajetória recente das instituições democráticas brasileiras demonstra serem estas um terreno pouco propício à sobrevivência de velhos e novos chefes políticos na esfera estadual, não obstante o substancial repertório de poderes formais e informais acumulados pelos governadores dos estados ao longo do recente período democrático” (BORGES, op. cit., p. 186).

Neste caso, caberia indagarmos se as mesmas conclusões se aplicariam a Estados com melhores condições de desenvolvimento, arrecadação e - por consequência - capacidade de indução política nos municípios. Sugerimos, assim, que é 
plausível a hipótese de que a preponderância do governo central e sua possibilidade de "conexão direta" federativa em relação aos municípios podem ter características distintas em contextos de governos estaduais com maiores capacidades institucionais e financeiras - situação essa que se aplica ao Estado de São Paulo. Em outras palavras, em um Estado como São Paulo, a máquina do governo ainda possuiria importantes alavancas de intermediação (se observarmos sob a ótica crítica do conceito do “clientelismo") junto ao eleitorado. Por outro lado, vale lembrar que, sob o prisma da escola teórica do "voto econômico", eleitores recompensam governantes bem avaliados na hora das eleições. Futuras pesquisas que utilizem variáveis como investimentos, transferências diretas via convênios e alocações orçamentárias diversas do governo do Estado para suas diferentes regiões e municípios, bem como o próprio nível de avaliação dos governantes paulistas, poderão apontar indícios nesse sentido.

Destacamos, por fim, conforme mencionado inúmeras vezes ao longo deste trabalho, que, em termos socioeconômicos, o Estado de São Paulo possui características peculiares se comparados às unidades federativas brasileiras, tais como o menor número de eleitores de estratos mais pobres e nível de desenvolvimento econômico mais elevado - ressalvadas regiões de carência significativa, como o Pontal do Paranapanema, o Sudoeste Paulista, o Vale do Ribeira e as franjas periféricas das grandes metrópoles.

Mesmo nestes locais e na faixa de eleitorado de menores rendimentos e escolaridade, porém, verificamos que é significativo o apoio aos candidatos tucanos após 2006 - eleição paradigmática em termos nacionais, de acordo com a literatura fartamente apontada nesta dissertação. Observamos que, de maneira geral, o PSDB manteve um apoio expressivo nas classes populares no Estado de São Paulo, sendo que no interior não há distinções de monta no apoio ao partido, mesmo quando olhados conjuntamente locais de maior ou menor desenvolvimento.

Este panorama traz novos elementos para análise do que se convencionou denominar de "conservadorismo popular" (PIERUCCI, 1987; PIERUCCI \& LIMA, 1991; SINGER, 1999). Identificado sobremaneira como um fenômeno urbano em contextos de modificações sociais aceleradas (tais como migração, industrialização e ascensão social de determinadas camadas da população), em São Paulo, o conservadorismo popular pode ter adquirido novas configurações no período recente. 
Diversos trabalhos de caráter etnográfico (OLIVEIRA, 2013; VALLE, 2014; COSTA, 2015) têm buscado identificar de que maneira os valores ideológicos, crenças e outros elementos identitários conectam-se com as escolhas políticas (sobretudo em termos de voto) dos eleitores.

Nesta pesquisa, observamos, a partir de métodos quantitativos, a prevalência de um expressivo apoio popular aos candidatos do PSDB em São Paulo, de encontro ao perfil nacional de votação no partido - apoio este ainda mais relevante no interior do Estado. Abordagens "localizadas" junto aos eleitores - sobremaneira qualitativas podem elucidar de maneira mais precisa os mecanismos acionados na construção de suas preferências. 


\section{Bibliografia}

ABRUCIO, Fernando. Os Barões da Federação - Os Governadores e a Redemocratização Brasileira. São Paulo: Hucitec, 1998.

AMARAL, Osvaldo E. “O que Sabemos sobre a Organização dos Partidos Políticos: Uma Avaliação de 100 Anos de Literatura". Revista Debates, v.7, n.2, Maio-Agosto de 2013.

ARRETCHE, Marta. Estado Federativo e Politicas Sociais: Determinantes da Descentralização. Rio de Janeiro: Revan, 2000.

BALBACHEVSKY, Elisabeth; HOLZHACKER, Denilde. "Identidade, Corporação e Pragmatismo: o Conteúdo Estratégico da Decisão Eleitoral em 13 Anos de Eleições". Opinião Pública, Campinas, v. X, n. 2, p. 242-253, 2004.

BENEVIDES, Maria Vitória. “O Velho PTB Paulista (Partido, Sindicato e Governo em São Paulo - 1945/1964)”. Lua Nova, n. 17, Junho de 1989.

BIZARRO NETO, Fernando Augusto; FREITAS, Vitor Eduardo Veras de Sandes. “Organização Faz Diferença? Estruturas Partidárias, Filiados e Votos em São Paulo nas Eleições de 2010”. Revista Eletrônica de Ciência Política, vol. 2, n. 2, 2011.

BIZARRO NETO, Fernando Augusto. PMDB: Organização e Desenvolvimento em São Paulo (1994-2010). Dissertação de Mestrado (IFCH/Unicamp). Campinas, 2013.

BORGES, André. “Já Não se Fazem Mais Máquinas Políticas como Antigamente: Competição Vertical e Mudança Eleitoral nos Estados Brasileiros". Revista de Sociologia e Política, v. 18, 2010. 
CARDOSO, Fernando Henrique. Partidos e Deputados em São Paulo (o Voto e a Representação Política). In: ; LAMOUNIER, Bolivar (org.). Os Partidos e as Eleições no Brasil. Rio de Janeiro: Paz e Terra, 1978.

CARREIRÃO, Yan de Souza. A Decisão do voto nas Eleições Presidenciais do Brasil (1989 a 1998): a Importância do Voto por Avaliação do Desempenho. Rio de Janeiro: Editora FGV, 2002.

CARREIRÃO, Yan de Souza. KINZO, Maria D'Alva Gil. "Partidos Políticos, Preferência Partidária e Decisão Eleitoral no Brasil (1989/2002)". Revista de Ciências Sociais, Vol. 47, n. 1, 2004.

CESOP UNICAMP. Intenção de Voto para Governador São Paulo 1990 Datafolha/SP90.nov-00234. In: Banco de Dados do Centro de Estudos de Opinião Pública - CESOP-UNICAMP. Disponível em:

<http://www.cesop.unicamp.br/busca/CESOP/pesquisa_usuario>. Acessado em 07/03/2015.

CESOP UNICAMP. Intenção de Voto para Governador São Paulo 1994 Datafolha/Brasil94.set-00377. In: Banco de Dados do Centro de Estudos de Opinião Pública - CESOP-UNICAMP. Disponível em:

<http://www.cesop.unicamp.br/busca/CESOP/pesquisa_usuario $>. \quad$ Acessado em 07/03/2015.

CESOP UNICAMP. Intenção de Voto para Governador São Paulo 1998 Datafolha/SP98.out-00916. In: Banco de Dados do Centro de Estudos de Opinião Pública - CESOP-UNICAMP. Disponível em: 
〈http://www.cesop.unicamp.br/busca/CESOP/pesquisa_usuario $>$.

Acessado em

07/03/2015.

CESOP UNICAMP. Intenção de Voto para Governador São Paulo 1998 -

Datafolha/SP98.out-00933. In: Banco de Dados do Centro de Estudos de Opinião Pública - CESOP-UNICAMP. Disponível em:

〈http://www.cesop.unicamp.br/busca/CESOP/pesquisa_usuario $>. \quad$ Acessado em 07/03/2015.

CESOP UNICAMP. Intenção de Voto para Governador São Paulo 2002Datafolha/SP02.out-01831. In: Banco de Dados do Centro de Estudos de Opinião Pública - CESOP-UNICAMP. Disponível em:

〈http://www.cesop.unicamp.br/busca/CESOP/pesquisa_usuario $>$ Acessado em 07/03/2015.

COSTA, Henrique B. Entre o Lulismo e o Ceticismo. Um Estudo de Caso com Prounistas de São Paulo. Dissertação de Mestrado (FFLCH/USP). São Paulo: 2015.

COSTA, Vicente da; FERRARI, Levi Bucalem. Uma Análise da Campanha. In: SADEK, Maria Tereza et alli. Eleições - 1986. São Paulo: Vértice / IDESP, 1989.

DAVIDIAN, Andreza. A Evolução do PT Paulista: Uma Abordagem sobre a Organização do Partido e seu Desenvolvimento Eleitoral no Estado. Dissertação de Mestrado (FFLCH/USP). São Paulo, 2013.

DUAILIB, Julia. “O Paulista Ge-Ral-Do”. Revista Piauí, n 99, Dezembro de 2014.

DUVERGER, Maurice. Os Partidos Políticos. Rio de Janeiro: Zahar/UnB, 1980. 
FARIA, Vilmar. As Eleições de 1974 no Estado de São Paulo: Uma Análise das Variações Inter-regionais. In: In: CARDOSO, Fernando Henrique; LAMOUNIER, Bolivar (org.). Os Partidos e as Eleições no Brasil. Rio de Janeiro: Paz e Terra, 1978.

FERREIRA, Oliveiros. "A Crise de Poder do 'Sistema' e as Eleições Paulistas de 1962”. Revista Brasileira de Estudos Políticos, n. 16, 1964.

FIGUEIREDO, Marcus. A Decisão do Voto - Democracia e Racionalidade. São Paulo: Editora Sumaré, 1991.

FIGUEIREDO FILHO, D. B; SILVA JR. J.A. "Desvendando os Mistérios do Coeficiente de Correlação de Pearson (r)”. Revista Política Hoje, vol. 116 18, n. 1, 2009.

FIORE, Danilo C. "Dimensões Eleitorais do Predomínio do PSDB em São Paulo (19942010)”. Apresentação ao IV Seminário Discente do Programa de Pós-Graduação em Ciência Política. São Paulo, 2014.

FOLHA DE SÃO PAULO. "Covas Ainda Lidera mas Perde Votos na Elite”, 12 de Novembro de 1994, p. 1/11.

GRIMBERG, Lucia. Partido Político ou Bode Expiatório? Um Estudo sobre a Aliança Renovadora Nacional - ARENA (1965-1979). Rio de Janeiro: Mauad X, 2009.

GUIMARÃES, Juarez. “As Razões do PSDB”. Teoria e Debate, Volume 82, Maio / Junho de 2009.

HUNTER, Wendy; POWER, Timothy J. Recompensando Lula - Poder Executivo, Política Social e as Eleições Brasileiras de 2006. In: MELO, Carlos Ranulfo; SÁEZ, Manuel Alcántara (org.). A Democracia Brasileira - Balanços e Perspectivas para o Século 21. Belo Horizonte: Editora UFMG, 2007. 
KINZO, Maria D’Alva G. Gênese e Trajetória do MDB (1966-1979). São Paulo: Vértice / IDESP, 1988.

LAMOUNIER, Bolívar. "Presidente Prudente: O Crescimento da Oposição num Reduto Arenista”. In: REIS, Fabio Wanderley (org). Os Partidos e o Regime - A Lógica do Processo Eleitoral Brasileiro. São Paulo: Edições Símbolo, 1978.

LAMOUNIER, Bolívar. O Voto em São Paulo - 1970-1978. In: (org.) Voto de Desconfiança. Rio de Janeiro: Vozes, 1980.

LIMONGI, Fernando; CORTEZ, Rafael. “As Eleições de 2010 e o Quadro Partidário”. Novos Estudos CEBRAP, n. 88, Dezembro de 2010.

LIMONGI, Fernando; GUARNIERI; Fernando. "A Base e os Partidos: As Eleições Presidenciais no Brasil Pós-Redemocratização”. Novos Estudos CEBRAP, n. 99, Julho de 2014.

LIMONGI, Fernando; MESQUITA, Lara. "Estratégia Partidária e Preferência dos Eleitores - As Eleições Municipais em São Paulo entre 1985 e 2004”. Novos Estudos CEBRAP, n. 81, Julho de 2008.

LIPSET, Seymour M. O Homem Político. Rio de Janeiro: Zahar Editores, 1967.

LIPSET, Seymour M. 2001. "The Americanization of the European Left". Journal of Democracy, Vol. 12, n. 2, 2001.

MELHEM, Celia. Política de Botinas Amarelas: O MDB-PMDB Paulista de 1965 a 1988. São Paulo: Hucitec, 1998.

MENEGHELlO, Rachel; BIZARRO NETO, Fernando. "Contexto e Competição na Política Paulista”. Dados - Revista de Ciências Sociais, vol. 55, n. 1, 2012. 
MICHELS, Robert. Sociologia dos Partidos Políticos. Brasília: UNB, 1982

NICOLAU, Jairo; PEIXOTO, Vitor. Uma Disputa em Três Tempos: Uma Análise das Bases Municipais das Eleições Presidenciais de 2006. XXXI Encontro Anual da ANPOCS. Caxambu, 2007.

PIERUCCI, Antonio Flavio. “As Bases da Nova Direita”. Novos Estudos Cebrap, n. 19, Dezembro de 1987.

PIERUCCI, Antonio Flávio; LIMA, Marcelo Coutinho de. “A Direita que Flutua - o Voto Conservador na Eleição de 1990 em São Paulo". Novos Estudos CEBRAP, n. 29, Março de 1991.

REIS, Fabio Wanderley; CASTRO, Mônica Mata Machado de. "Regiões, classe e ideologia no processo eleitoral brasileiro". Lua Nova, n. 26, 1992.

OLIVEIRA, Camilla R. Encontros e desencontros entre petismo e lulismo: classe, ideologia e voto na periferia de São Paulo. Dissertação de Mestrado (FFLCH/USP). São Paulo: 2013.

ROMA, Celso. “A Institucionalização do PSDB entre 1988 e 1999”. Revista Brasileira de Ciências Sociais, vol. 17, n. 49, Junho de 2002.

SADEK, Maria Tereza. Concentração Industrial e Estrutura Partidária - O Processo Eleitoral no ABC (1966-1982). Tese de Doutorado (FFLCH/USP). São Paulo, 1984.

SADEK, Maria Tereza. A Interiorização do PMDB nas Eleições de 1986 em São Paulo. In: et alli (org.). Eleições - 1986. São Paulo: Vértice / IDESP, 1989. 
SEADE, Fundação. Índice Paulista de Vulnerabilidade Social - IPVS Versão 2010. São

Paulo: $2010 \quad$ (disponível em $\quad$ http://indices-

ilp.al.sp.gov.br/view/pdf/ipvs/principais_resultados.pdf; acesso em 09/09/2015).

SEANWRIGHT, Jason; GERRING, John. "Case Selection Techniques in Case Study Research”. Political Research Quarterly, Vol. 61, n. 2, Junho de 2008.

SIMONI JR, Sergio. Flutuação Eleitoral e Sistema Partidário: O Caso de São Paulo. Dissertação de Mestrado (FFLCH/USP). São Paulo, 2012.

SIMÃO, Aziz. O Voto Operário em São Paulo. Anais do Primeiro Congresso Brasileiro de Sociologia, 1955.

SINGER, André. Esquerda e Direita no Eleitorado Brasileiro. São Paulo: EDUSP, 1999.

Os Sentidos do Lulismo: Reforma Gradual e Pacto Conservador.

São Paulo: Cia. Das Letras, 2012.

SOARES, Gláucio Ary Dilon. Sociedade e Política no Brasil. São Paulo: Difel, 1973. ; TERRON, Sonia Luiza. "As bases Eleitorais de Lula e do PT: do Distanciamento ao Divórcio”. Opinião Pública, vol. 16, n. 2, 2010.

VALle, Vinicius S. M. Pentecostalismo e Lulismo na Periferia de São Paulo: Estudo de Caso sobre uma Assembleia De Deus na Eleição Municipal De 2012. Dissertação de Mestrado (FFLCH/USP). São Paulo, 2014.

WEBER, Max. Ciência e Política - Duas Vocações. São Paulo: Cultrix: 2011.

WEFFORT, Francisco. "Raízes Sociais do Populismo em São Paulo". Revista Civilização Brasileira, n. 2, 1964. 
ZUCCO JR., Cesar. “The President's 'New' Constituency: Lula and the Pragmatic Vote in Brazil's 2006 Presidential Elections”. Journal of Latin American Studies, n. 40, 2008.

$\underline{\text { Sítios }}$

Acervo "Folha de São Paulo - http://acervo.folha.com.br/

CESOP - $\underline{\text { www.cesop.unicamp.br }}$

Datafolha - www.datafolha.folha.uol.com.br

Fundação SEADE - www.seade.sp.gov.br

Instituto Brasileiro de Geografia e Estatística - www.ibge.gov.br

Síntese de Indicadores Sociais 2014 - Uma Análise das Condições de Vida da População Brasileira - http://www.ibge.gov.br/estadosat

Investe SP - www.investe.sp.gov.br

Paulística eleitoral (TRE-SP) - $\quad$ http://www.tre-sp.jus.br/eleicoes/eleicoesanteriores/sistema-paulistica

Portal da Legislação do Governo Federal - www.planalto.gov.br/legislacao

Portal "Território de Desenvolvimento" - www.mapaderesultados.mg.gov.br

Subsecretaria de Assuntos Metropolitanos da Casa Civil do Governo do Estado de São Paulo - http://www.sdmetropolitano.sp.gov.br

Tribunal Superior Eleitoral - $\underline{\text { www.tse.jus.br }}$

Youtube - $\underline{\text { www.youtube.com.br }}$ 
ANEXO I - Resultados Gerais - Eleições para Governador do Estado de São Paulo (1982-2014) - Principais Candidatos

\begin{tabular}{|c|c|c|c|c|c|}
\hline \multicolumn{6}{|c|}{ Eleições de 1982} \\
\hline CANDIDATO & PARTIDO & VOTOS VÁLIDOS $(\%)$ & & & \\
\hline Andre Franco Montoro & PMDB & $49,03 \%$ & & & \\
\hline Reynaldo de Barros & PDS/PP & $25,68 \%$ & & & \\
\hline Janio Quadros & PTB & $13,62 \%$ & & & \\
\hline Luiz Inacio Lula da Silva & PT & $10,77 \%$ & & & \\
\hline Outros & - & $0,89 \%$ & & & \\
\hline \multicolumn{6}{|c|}{ Eleições de 1986} \\
\hline CANDIDATO & PARTIDO & VOTOS VÁLIDOS (\%) & & & \\
\hline Orestes Quércia & PMDB & $40,78 \%$ & & & \\
\hline Antonio Ermirio de Moraes & PTB & $26,86 \%$ & & & \\
\hline Paulo Maluf & PDS/PP & $19,50 \%$ & & & \\
\hline Eduardo Suplicy & PT & $11,03 \%$ & & & \\
\hline Outros & - & $1,83 \%$ & & & \\
\hline \multicolumn{6}{|c|}{ Eleições de 1990} \\
\hline \multicolumn{3}{|c|}{$1^{\circ}$ Turno } & \multicolumn{3}{|c|}{$2^{\circ}$ Turno } \\
\hline CANDIDATO & PARTIDO & VOTOS VÁLIDOS (\%) & CANDIDATO & PARTIDO & VOTOS VÁLIDOS (\%) \\
\hline Paulo Maluf & PDS/PP & $43,50 \%$ & Luiz Antonio Fleury Filho & PMDB & $51,77 \%$ \\
\hline Luiz Antonio Fleury Filho & PMDB & $28,17 \%$ & Paulo Maluf & PDS/PP & $48,23 \%$ \\
\hline Mario Covas & PSDB & $15,19 \%$ & & & \\
\hline Plinio de A. Sampaio & PT & $12,12 \%$ & & & \\
\hline Outros & - & $1.01 \%$ & & & \\
\hline \multicolumn{6}{|c|}{ Eleiç̃es de 1994} \\
\hline \multicolumn{3}{|c|}{$1^{\circ}$ Turno } & \multicolumn{3}{|c|}{$2^{\circ}$ Turno } \\
\hline CANDIDATO & & VOTOS VÁLIDOS (\%) & CANDIDATO & PARTIDO & VOTOS VÁLIDOS (\%) \\
\hline Mario Covas & PSDB & $46,84 \%$ & Mario Covas & PSDB & $56,12 \%$ \\
\hline Francisco Rossi & PDT & $22,23 \%$ & Francisco Rossi & PDT & $43,88 \%$ \\
\hline José Dirceu & PT & $14,86 \%$ & & & \\
\hline Barros Munhoz & PMDB & $11,29 \%$ & & & \\
\hline Luiz Antonio Medeiros & PP* & $2,26 \%$ & & & \\
\hline Outros & - & $2,52 \%$ & & & \\
\hline \multicolumn{6}{|c|}{ Eleições de 1998} \\
\hline \multicolumn{3}{|c|}{$1^{\circ}$ Turno } & \multicolumn{3}{|c|}{$2^{\circ}$ Turno } \\
\hline CANDIDATO & PARTIDO & VOTOS VÁLIDOS $(\%)$ & CANDIDATO & PARTIDO & VOTOS VÁLIDOS (\%) \\
\hline Paulo Maluf & PDS/PP & $32,21 \%$ & Mario Covas & PSDB & $55,36 \%$ \\
\hline Mario Covas & PSDB & $22,95 \%$ & Paulo Maluf & PDS/PP & $44,63 \%$ \\
\hline Marta Suplicy & $\begin{array}{l}\text { PT } \\
\text { PT }\end{array}$ & $22,50 \%$ & & & \\
\hline Francisco Rossi & PDT & $17,11 \%$ & & & \\
\hline Orestes Quercia & PMDB & $4,29 \%$ & & & \\
\hline Outros & - & $0,94 \%$ & & & \\
\hline
\end{tabular}

\begin{tabular}{|c|c|c|c|c|c|}
\hline \multicolumn{6}{|c|}{ Eleições de 2002} \\
\hline \multicolumn{3}{|c|}{$1^{\circ}$ Turno } & \multicolumn{3}{|c|}{$2^{\circ}$ Turno } \\
\hline CANDIDATO & PARTIDO & VOTOS VÁLIDOS (\%) & CANDIDATO & PARTIDO & VOTOS VÁLIDOS (\%) \\
\hline Geraldo Alckmin & PSDB & $38,28 \%$ & Geraldo Alckmin & \begin{tabular}{|l|l|} 
PSDB \\
\end{tabular} & $58,64 \%$ \\
\hline José Genoino & PT & $32,44 \%$ & \begin{tabular}{|l|} 
José Genoino \\
\end{tabular} & PT & $41,36 \%$ \\
\hline Paulo Maluf & PDS/PP & $21,37 \%$ & & & \\
\hline Carlos Apolinário & PGT & $3,59 \%$ & & & \\
\hline Outros & - & $4,31 \%$ & & & \\
\hline \multicolumn{6}{|c|}{ Eleições de 2006} \\
\hline \multicolumn{3}{|c|}{$1^{\circ}$ Turno } & & & \\
\hline CANDIDATO & PARTIDO & VOTOS VÁLIDOS (\%) & & & \\
\hline José Serra & PSDB & $57,92 \%$ & & & \\
\hline Aloizio Mercadante & PT & $31,68 \%$ & & & \\
\hline Orestes Quercia & PMDB & $4,57 \%$ & & & \\
\hline Plinio de A. Sampaio & PSOL & $2,49 \%$ & & & \\
\hline Carlos Apolinário & PDT & $2,02 \%$ & & & \\
\hline Outros & - & $1,32 \%$ & & & \\
\hline \multicolumn{6}{|c|}{ Eleições de 2010} \\
\hline \multicolumn{3}{|c|}{$1^{\circ}$ Turno } & & & \\
\hline CANDIDATO & PARTIDO & VOTOS VÁLIDOS (\%) & & & \\
\hline Geraldo Alckmin & PSDB & $50,63 \%$ & & & \\
\hline Aloizio Mercadante & PT & $35,23 \%$ & & & \\
\hline Celso Russomano & PDS/PP & $5,42 \%$ & & & \\
\hline Paulo Skaff & PSB & $4,56 \%$ & & & \\
\hline Fabio Feldmann & PV & $4,13 \%$ & & & \\
\hline Outros & - & $0,03 \%$ & & & \\
\hline \multicolumn{6}{|c|}{ Eleições de 2014} \\
\hline \multicolumn{3}{|c|}{$1^{\circ}$ Turno } & & & \\
\hline CANDIDATO & PARTIDO & VOTOS VÁLIDOS (\%) & & & \\
\hline Geraldo Alckmin & PSDB & $57,31 \%$ & & & \\
\hline Paulo Skaff & PMDB & $21,53 \%$ & & & \\
\hline Alexandre Padilha & PT & $18,22 \%$ & & & \\
\hline Outros & - & $2,94 \%$ & & & \\
\hline
\end{tabular}

Fonte: TSE 
ANEXO II - Candidato à Prefeitura de São Paulo e ao Governo do Estado de São Paulo (1982-2014) - Principais Partidos

\begin{tabular}{|c|c|c|c|c|c|}
\hline \multicolumn{2}{|c|}{ Eleição } & \multicolumn{4}{|c|}{ Partido / Candidato } \\
\hline Ano & Cargo & PDS/PP & PMDB & PSDB & PT \\
\hline 1982 & Governo & Reynaldo de Barros & Franco Montoro & & Luis Inácio Lula da Silva \\
\hline 1985 & Prefeitura & Apoio Jânio (PTB) & Fernando Henrique Cardoso & & Eduardo Suplicy \\
\hline 1986 & Governo & Paulo Maluf & Orestes Quércia & & Eduardo Suplicy \\
\hline 1988 & Prefeitura & Paulo Maluf & João Leiva & José Serra & Luiza Erundina \\
\hline 1990 & Governo & Paulo Maluf & Luiz Antonio Fle ury Filho & Mario Covas & Plinio de Arruda Sampaio \\
\hline 1992 & Prefeitura & Paulo Maluf & Aloysio Nunes Ferreira & Fabio Feldmann & Eduardo Suplicy \\
\hline 1994 & Governo & Apoio Medeiros (PP*) & Barros Munhoz & Mario Covas & José Dirceu \\
\hline 1996 & Prefeitura & Celso Pitta & José A. Pinotti & José Serra & Luiza Erundina \\
\hline 1998 & Governo & Paulo Maluf & Orestes Quércia & Mario Covas & Marta Suplicy \\
\hline 2000 & Prefeitura & Paulo Maluf & Apoio Tuma (PFL/DEM) & Geraldo Alckmin & Marta Suplicy \\
\hline 2002 & Governo & Paulo Maluf & Lamartine Posella & Geraldo Alckmin & José Genoino \\
\hline 2004 & Prefeitura & Paulo Maluf & Apoio Erundina (PSB) & José Serra & Marta Suplicy \\
\hline 2006 & Governo & Apoio Quércia (PMDB) & Orestes Quércia & José Serra & Aloizio Mercadante \\
\hline 2008 & Prefeitura & Paulo Maluf & Apoio Kassab (PFL/DEM) & Geraldo Alckmin & Marta Suplicy \\
\hline 2010 & Governo & Celso Russomano & Apoio Alckmin (PSDB) & Geraldo Alckmin & Aloizio Mercadante \\
\hline 2012 & Prefeitura & Apoio Haddad (PT) & Gabriel Chalita & José Serra & Fernando Haddad \\
\hline 2014 & Governo & Apoio Skaf (PMDB) & Paulo Skaf & Geraldo Alckmin & Alexandre Padilha \\
\hline
\end{tabular}

Em negrito, candidato (a) vencedor (a)

* Partido Progressista, formado em 1992 a partir da fusão do PTR com PST; em 1995, fundiu-se ao PPR (sucessor do PDS) para formar o PPB (atual PP).

Fonte: Portal "Paulística Eleitoral"; TSE. 
ANEXO III - Coligações Partidárias (Principais Partidos) em São Paulo (19822014)

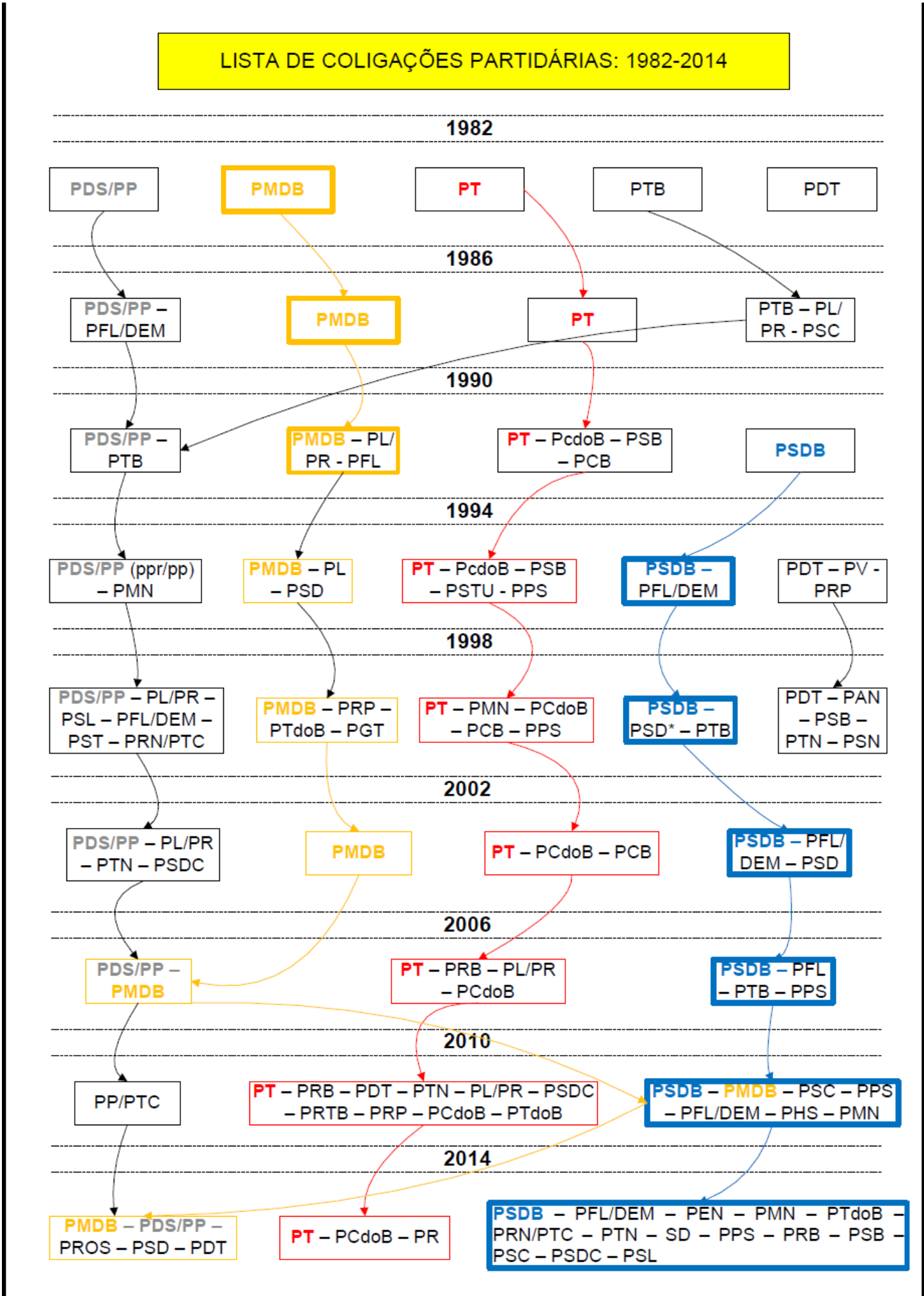

* Trata-se de partido que incorporou-se ao PTB em 2003, distinto da agremiação de mesmo nome fundada por dissidentes do PFL/DEM em 2011. Fonte: TSE 